rev. hist. (São Paulo), n. 171, p. 245-286, jul.-dez., 2014 http://dx.doi.org/10.11606/issn.2316-9141.rh.2014.89013

\section{DEUS E O DIABO NA BIBLIOTECA DE UM CÔNEGO DA BAHIA: O INVENTÁRIO DOS LIVROS DO PADRE MANOEL DENDÊ BUS}

\section{EM 1836}

\section{Contato}

Rua Professor José Seabra, $\mathrm{s} / \mathrm{n}$ Centro de Humanidades da Ufob 47805-100 - Barreiras - Bahia E-mail: pimagalhaes@yahoo.com.br
Pablo Antonio Iglesias Magalhães*

Universidade Federal do Oeste da Bahia

\title{
Resumo
}

O presente artigo investiga e cataloga a biblioteca particular do cônego da Sé da Bahia, Manoel José de Freitas Baptista Mascarenhas (Manoel Dendê Bus). O inventário do referido padre traz a lista de 176 obras arroladas pelo livreiro e impressor José Paulo Franco Lima em 1836. A partir desta lista foi possível identificar e reconstruir um catálogo de uma biblioteca privada formada na Bahia entre o fim do período colonial e a Regência.

\section{Palavras-chave}

Catálogo de biblioteca oitocentista brasileira - circulação de impressos - livros raros na Bahia colonial.

* Doutor em História Social pela Universidade Federal da Bahia e professor adjunto I de História do Brasil, no Centro das Humanidades. 
rev. hist. (São Paulo), n. 171, p. 245-286, jul.-dez., 2014 http://dx.doi.org/10.11606/issn.2316-9141.rh.2014.89013
Pablo Antonio Iglesias Magalhães

Deus e o diabo na biblioteca de um cônego da Bahia: 0 inventário dos livros do padre Manoel Dendê Bus em 1836

\title{
GOD AND THE DEVIL \\ IN THE LIBRARY OF \\ A CANON OF THE \\ BAHIA: \\ THE INVENTORY OF \\ BOOKS OF THE PRIEST \\ MANOEL DENDÊ BUS \\ IN 1836
}

Contact

Rua Professor José Seabra, s/n Centro de Humanidades da Ufob 47805-100 - Barreiras - Bahia

E-mail: pimagalhaes@yahoo.com.br

Pablo Antonio Iglesias

\section{Magalhães}

Universidade Federal do Oeste da Bahia

\begin{abstract}
This article investigates and catalogs the private library of the cônego of the Sé of Bahia, Manuel José Baptista de Freitas Mascarenhas (Manoel Dendê Bus). His inventory shows the list of enrolled 176 works by the bookseller and printmaker José Paulo Franco Lima in 1836. This list allows to identify and reconstruct the catalog of a private library formed in Bahia between the end of the colonial period and the Regency.
\end{abstract}

\section{Keywords}

Nineteenth-century Brazil library catalog - circulation of imprinted - rare books in colonial Bahia. 
rev. hist. (São Paulo), n. 171, p. 245-286, jul.-dez., 2014 http://dx.doi.org/10.11606/issn.2316-9141.rh.2014.89013
Pablo Antonio Iglesias Magalhães

Deus e o diabo na biblioteca de um cônego da Bahia: 0 inventário dos livros do padre Manoel Dendê Bus em 1836

\section{Dendê Bus}

A história das bibliotecas privadas no Brasil colonial foi iniciada em 1945, há 70 anos, por meio da publicação de $O$ diabo na bibioteca do cônego, estudo clássico de Eduardo Frieiro que analisou o traslado do auto de sequestro feito nos bens que se acharam em casa do cônego Luís Vieira da Silva. Implicado na Inconfidência Mineira e admirador das ideias da Ilustração, Vieira da Silva possuía, então, 270 títulos distribuídos em 800 volumes. ${ }^{1}$ Frieiro percebeu, na coleção de livros do cônego Silva, a presença de abomináveis princípios franceses que inspiraram seu grupo político na contestação às estruturas coloniais impostas pelas autoridades portuguesas.

Depois da obra de Frieiro, outros estudos acerca das bibliotecas particulares tiveram lugar. Luiz Carlos Villata investigou os livros apreendidos aos demais inconfidentes. ${ }^{2}$ Ainda para a capitania de Minas Gerais, Junia Ferreira Furtado analisou a biblioteca do naturalista José Vieira Couto, que contava 238 títulos em 601 volumes. ${ }^{3}$ Borba Moraes publicou a lista de livros da biblioteca de Manoel Inácio da Silva Alvarenga. ${ }^{4}$ Márcia Abreu identificou bibliotecas privadas no Rio de Janeiro ${ }^{5}$ e Gilda Verri estudou a entrada de livros na capitania de Pernambuco e na Paraíba na transição do século XVIII para o XIX, usando a documentação da Real Mesa Censória. ${ }^{6}$

Sobre a capitania da Bahia pouco se avançou nos últimos quarenta anos. Coube a Katia Queirós Mattoso discutir o conteúdo das bibliotecas privadas apreendidas a Cipriano Barata e ao tenente Hermógenes de Aguiar

1 FRIEIRO, Eduardo. O diabo na livraria do cônego. Edições Cultura Brasileira, 1945.

2 VILLALTA, Luiz Carlos. O diabo na livraria dos inconfidentes. In: NOVAES, Adauto (org.). Tempo e história. São Paulo: Companhia das Letras; Secretaria Municipal de Cultura, 1992, p. 267-295. Do mesmo autor, ver também: VILLALTA, L. C. Governadores, bibliotecas e práticas de leitura. Atalaia, Lisboa, v. 6/7, 2000, p. 277-286. VILLALTA, L. C. \& MORAIS, Christianni Cardoso. Posse de livros e bibliotecas privadas em Minas Gerais (1714-1874). In: BRAGANÇA, Aníbal \& ABREU, Márcia (org.). Impresso no Brasil - Dois séculos de livros brasileiros. São Paulo: Editora Unesp, 2010, p. 401-418.

3 FURTADO, Junia Ferreira. Sedição, heresia e rebelião nos trópicos: a biblioteca do naturalista José Vieira Couto. In: DUTRA, Eliana \& MOLLIER, Jean-Yves (org.). Política, nação e edição: o lugar dos impressos na construção da vida política: Brasil, Europa e Américas nos séculos XVIII-XX. São Paulo: Annablume, p. 72.

${ }^{4}$ MORAES, Rubens Borba de. Livros e bibliotecas no Brasil colonial. São Paulo: SCTT, 1979, p. 185-195.

5 ABREU, Márcia. Uma biblioteca particular, dois proprietários e nenhum perfil de leitor. Um estudo dos livros de Daniel Pedro e João Guilherme Christiano Müller. In: ANASTÁCIO, Vanda. (org.). Tratar, estudar, disponibilizar: um futuro para as bibliotecas particulares, v. 1. Lisboa: B. E. S., 2013, p. 59-70.

${ }^{6}$ VERRI, Gilda M. W. Tinta sobre papel: Livros e leituras em Pernambuco no século XVIII. Recife: Editora Universitária da UFPE, 2006, 2 v. 
rev. hist. (São Paulo), n. 171, p. 245-286, jul.-dez., 2014 http://dx.doi.org/10.11606/issn.2316-9141.rh.2014.89013
Pablo Antonio Iglesias Magalhães

Deus e o diabo na biblioteca de um cônego da Bahia: 0 inventário dos livros do padre Manoel Dendê Bus em 1836

Pantoja, personagens implicados na Conjuração Baiana de 1798. ${ }^{7}$ Apesar destes competentes estudos, Villata observou, acertadamente, que "a historia do livro no Brasil colonial está, em grande parte, ainda por se escrever. De fato, são inúmeros os silêncios e as lacunas da historiografia no que tange aos livros, às bibliotecas e às práticas de leituras no Brasil colonial". ${ }^{8}$

Em síntese, na falta de catálogos de bibliotecas privadas brasílicas, sendo o primeiro catálogo de livros particulares publicado apenas em 1907, os historiadores encontraram três fontes para conhecer as bibliotecas e os hábitos de leitura na colônia: os fundos da Real Mesa Censória, os autos das devassas e os livros inventariados em testamentos. Os inventários são o mais promissor pelo seu ineditismo, já que os documentos produzidos nas devassas contra inconfidências e conjurações são bem conhecidos há décadas. Por essa razão, é imprescindível recuperar e divulgar os inventários dos nossos antigos ajuntadores de livros. Além disso, é possível relacionar essas infomações com a biografia dos seus proprietários.

Em relação à Província da Bahia, uma das mais interessantes coleções privadas que pude localizar no Arquivo Público do Estado da Bahia pertenceu ao cônego Manoel Dendê Bus. Aliás, o padre Dendê Bus foi um dos indivíduos mais ativos da Guerra de Independência da Bahia (1822-1823). Para entender sua biblioteca é necessário, primeiro, compreender esse homem contraditório. Alguns aspectos da sua biografia foram investigados por Manoel de Aquino Barbosa e Cândido da Costa e Silva. ${ }^{9}$ Manoel José de Freitas Baptista Mascarenhas, nome de batismo, nasceu na freguesia da Sé no Porto, em Portugal, a 6 de dezembro de 1784, filho de Manoel Gonçalves da Costa e Catarina Maria de Jesus, ambos portugueses. Ainda muito jovem, Manoel de Freitas Mascarenhas veio para a Bahia, onde frequentou estudos particulares. Foi ordenado presbítero aos 27 anos, em 25 de julho de 1812, pelo arcebispo d. fr. José de Santa Escolástica. No ano seguinte, 1813, foi nomeado vigário colado da freguesia de Nossa Senhora d'Ajuda da Vila de Jaguaripe, no Recôncavo baiano. Em seguida, foi nomeado, a 22 de junho de 1815, pro-

\footnotetext{
7 MATTOSO, Katia Queirós. Presença francesa no Movimento Democrático Baiano de 1798. Salvador: Itapuã, 1969, p. 18-33.

8 VILLALTA, L. C. Bibliothéques privées et pratique de lecture au Brésil colonial. In: COLLOQUE AUX TEMPS MODERNES: NAISSANCE DU BRÉSIL (1500-1808). Actes. Paris: PUF, 1998.

9 BARBOSA, Manoel de Aquino. Padre Manoel Dendê Bus: figura do movimento liberador de 1822 e vigário da Conceição da Praia. Salvador. Anais do Arquivo do Estado da Bahia, vol. 40, 1971, p. 171-209.
} 
rev. hist. (São Paulo), n. 171, p. 245-286, jul.-dez., 2014 http://dx.doi.org/10.11606/issn.2316-9141.rh.2014.89013
Pablo Antonio Iglesias Magalhães

Deus e o diabo na biblioteca de um cônego da Bahia: 0 inventário dos livros do padre Manoel Dendê Bus em 1836

fessor de Gramática Latina na Vila Nova da Rainha, sendo transferido a 14 de setembro do mesmo ano para a Vila da Cachoeira. ${ }^{10}$

Em 1819, Manoel de Freitas, no cargo de professor régio de latim na Vila de Cachoeira, encaminhou um requerimento solicitando licença para ir ao Rio de Janeiro, "para tratar assuntos de seu interesse". Não é possível verificar quais foram esses assuntos, mas o professor comprometeu-se a deixar um substituto na sua cadeira, "pago a sua custa"."1

Após transitar pelo Rio de Janeiro, não tardou para que o professor retornasse para a Bahia. Foi a Guerra de Independência que mudou a história de Manoel Baptista Mascarenhas. Mudou, inclusive, seu nome, sendo "rebatizado" como Manoel Dendê Bus, que adotou em 14 de março de 1823, no calor da luta contra os portugueses. Mudança, aliás, autorizada por despacho do governo e acompanhada do aviso público pela imprensa.

Teve papel destacado na Independência na Bahia. ${ }^{12}$ Foi eleito, pela Vila de Pedra Branca, membro do Conselho Interino da Província, eleito em Cachoeira, a 6 de setembro de 1822, para o governo provisório da Bahia e expulsão das forças lusitanas, então comandadas pelo brigadeiro Inácio Madeira de Mello. O padre Freitas era pessoa de confiança de José Antônio da Silva Castro, avô do poeta Castro Alves, que o fez se eleger representante de Pedra Branca. ${ }^{13}$ Com o início da Guerra de Independência e a ocupação de Salvador pelas tropas portuguesas chefiadas por Madeira de Mello, a Vila de Cachoeira, tornou-se, com certo exagero dos contemporâneos, a "Filadélfia

${ }^{10}$ SILVA, Cândido da Costa e. Os segadores e a messe: o clero oitocentista na Bahia. Salvador: EduFBA, 2000, p. 461-462.

${ }^{11}$ Biblioteca Nacional do Rio de Janeiro (BNRJ). Seção de Manuscritos; Coleção: Documentos Biográficos. C-0098,044, $\mathrm{n}^{\circ}$ 001. Requerimento encaminhado ao Ministério do Império, solicitando licença para vir ao Rio de Janeiro, por um ano, e compromete-se a deixar substituto na cadeira de latim, que leciona em Cachoeira, Bahia. Manuscrito. Sem local, 16 de janeiro de 1819. BNRJ. Seção de Manuscritos; Coleção: Documentos Biográficos. C-0098,044, nº 002. Requerimento encaminhado ao Ministério do Império, solicitando licença para vir ao Rio de Janeiro, para tratar assuntos de seu interesse, e comprometer-se a deixar um substituto na sua cadeira, pago a sua custa. “Diz Manoel José de Freitas, Presbitero Secular e Professor Regio de Latim nesta Villa da Caxoeira, que para tratar de certos arranjos, que lhe são indispensaveis, necessita de hir á Corte do Rio de Janeiro, e ter nella alguma demora, em quanto trata dos mesmos. Mas como o não pode fazer sem licença de V. Ex. ${ }^{a}$, recorre e a V. Ex. ${ }^{a}$, se digne conceder ao suppl. a licença requerida por hum anno, obrigando-se o mesmo a deixar no exercício da sua Cadeira hum Substituto pago por elle".

${ }^{12}$ MILTON, Aristides Augusto. Efemérides cachoeiranas. Revista do Instituto Geográfico e Histórico da Bahia (RIGHBA), vol. VI. Salvador: Imprensa Oficial, n. 10², 1899, p. 234.

${ }^{13}$ CALMON, Pedro. A vida de Castro Alves. Rio de Janeiro: José Olympio, 1947, p. 5. 
rev. hist. (São Paulo), n. 171, p. 245-286, jul.-dez., 2014 http://dx.doi.org/10.11606/issn.2316-9141.rh.2014.89013
Pablo Antonio Iglesias Magalhães

Deus e 0 diabo na biblioteca de um cônego da Bahia: 0 inventário dos livros do padre Manoel Dendê Bus em 1836

brasileira". ${ }^{14}$ Essa junta agiu imediatamente em três instâncias. As comissões de caixas militares, criadas nas diversas vilas do Recôncavo baiano, foram o primeiro objeto de seus cuidados, reformando-as e tirando-lhes as atribuições governativas que elas se tinham arrogado, de sorte que ficaram reduzidas a meros comissariados de guerra. Em segundo, estabeleceu um correio terrestre desde a Vila de São Francisco do Conde até a de São Jorge de Ilhéus, para facilitar as comunicações com os grandes proprietários rurais do sul da Bahia. Por fim, a 28 de setembro, assumiu o comando da força militar com o objetivo de obstar a insubordinação dos soldados. Em 21 de outubro, foi redigido um ofício para d. Pedro I, informando o governo do Rio de Janeiro destas ações e da situação do governo instalado em Cachoeira. ${ }^{15}$

Junto com o ofício, foram encaminhadas as Instruções a que se refere o officio acima, no qual Manoel Dendê Bus foi um dos onze signatários. Primeiro, solicitaram ao governo o envio de armas, munições e oficiais habilitados para comandar as tropas no Recôncavo. Segundo, propuseram a criação de um canal de comunicação entre a Corte e a Bahia. Em seguida, apresentaram a proposta de manutenção da junta que estava no governo da Bahia até a situação ser organizada pela via constitucional. Em quarto, vetar ao bispo de São Paulo, como diocesano mais antigo, apresentar vigário capitular para Salvador "por não haver, durante a ocupação da cidade, recurso algum eclesiástico na província". Quinto, definir o método de eleição e número de procuradores da província, bem como o número de deputados eleitos após o desmembramento da comarca de Sergipe. Sexto, resolver a questão dos prisioneiros políticos. Sétimo, providenciar recursos judiciais, pois a ocupação da capital a isolou dos tribunais superiores. Por fim, em oitavo, definir as tropas que deveriam guarnecer a Bahia após a retirada das tropas portuguesas. ${ }^{16}$

Manuel de Freitas foi um ardoroso defensor da causa da independência. Tão ardoroso que teria proposto uma ação política extrema: a execução de todos os europeus residentes na colônia. O jornalista Ignacio José de Macedo, redator da Idade d'Ouro do Brazil e de O Velho Liberal do Douro, defensor da manutenção do Brasil na condição de reino unido, revelou que "Até hum pobre Clerigo filho do Porto, que se fez Brazileiro para ser Vigário, e que era tido por muito Liberal, votou no governo da Cachoeira, que fossem assas-

\footnotetext{
${ }^{14}$ SILVA, Ignacio Accioli de Cerqueira. Memorias históricas e politicas de provincia da Bahia, vol. 2. Bahia: Typ. do Correio Mercantil, 1836, p. 104 e 150.

15 SILVA. Memorias, op. cit., p. 150-151.

${ }^{16}$ SILVA. Memorias, op. cit., p. 153-154.
} 
rev. hist. (São Paulo), n. 171, p. 245-286, jul.-dez., 2014 http://dx.doi.org/10.11606/issn.2316-9141.rh.2014.89013
Pablo Antonio Iglesias Magalhães

Deus e o diabo na biblioteca de um cônego da Bahia: 0 inventário dos livros do padre Manoel Dendê Bus em 1836

sinados todos os Europeos, excepto elle". ${ }^{17}$ Apesar de não declarar nominalmente o autor deste voto, os indícios apontam seguramente para Dendê Bus. Não havia outro vigário portuense na Junta de Cachoeira. Por ocupar-se da guerra, foi oficialmente afastado da docência de gramática e latim pelo Conselho Interino que nomeou para substituí-lo o padre Manuel Gomes de S. Leão, que foi depois vigário da Conceição da Feira. ${ }^{18}$

Após o 2 de julho e a saída das forças de Madeira de Mello, Dendê Bus seguiu novamente para o Rio de Janeiro, zarpando a 19 de julho no brigue de guerra Guarani. Chegou à Corte no dia 30, após 11 dias de viagem, acompanhado do $1 .^{\circ}$ tenente Vicente Jorge Croston, comandante do Guarani, do deputado Miguel Calmon Du Pin e Almeida, seu suplente Antonio Calmon Du Pin e Almeida, além de outros veteranos da guerra. ${ }^{19}$

O objetivo de Manoel Dendê Bus no Rio de Janeiro era pleitear alguns benefícios em reconhecimento dos serviços prestados na guerra, encontrando, contudo, alguns obstáculos. ${ }^{20}$ Recebeu, por fim, a comenda de Cavaleiro da Ordem Imperial do Cruzeiro ${ }^{21}$ e da Ordem de Cristo. ${ }^{22}$ Ainda na Corte, o vigário da Conceição da Praia requereu o direito de "usar do Sendal Roxo em consequencia da mercê, que teve das honras de cônego da Sé Metropolitana da Bahia". ${ }^{23}$ Após quase cinco meses na Corte, a 22 de novembro de 1823 partiu do Rio de Janeiro com destino a Salvador, no brigue Jupiter. ${ }^{24}$

A luta e a vitória sobre os portugueses impulsionou a carreira do padre Dendê Bus. A 27 de agosto de 1823, foi apresentado como vigário colado, por carta imperial, para a freguesia de Nossa Senhora da Conceição da Praia, cargo de que tomou posse em 16 de janeiro de 1824. Também por carta

${ }^{17}$ MACEDO, José Ignacio de. O Velho Liberal do Douro, n. 34. Lisboa: Imprensa da Rua dos Fanqueiros, 1833, p. 5.

${ }^{18}$ MILTON. Efemérides. RIGHBA, vol. VI, nº 10, 1899, p. 234.

${ }^{19}$ Diario do Governo, n 27, sexta-feira, 1 de agosto de 1823. Rio de Janeiro: Imprensa Nacional, p. 4.

${ }^{20}$ Diario do Governo, $\mathrm{n}^{\circ}$ 64, terça-feira, 16 de setembro de 1823. Rio de Janeiro: Imprensa Nacional, p. 4.

${ }^{21}$ BNRJ, Seção de Manuscritos, Coleção Documentos biográficos, C-0027,023, nº 002. Recibo passado pelo Ministério do Império a Manuel Dendê Bus, no valor de 20\$000, pelo pagamento da joia da Ordem do Cruzeiro. [S. 1.], 1823. “A F. 41 do Livro Primeiro, que nesta Chancellaria da Ordem Imperial do Cruzeiro serve de Receita, e Despesa com Marianno Antonio de Amorim Carrão, Thesoureiro da dita Ordem, lhe fica carregado a quantia de vinte mil reis $20 \$ 000$ que deu de joia Manoel Dendê Bus pela Mercê de Cavalleiro da sobredita Ordem. Rio de Janeiro 16 de outubro de 1823. Marianno Antonio Amorim Carrão". Diario do Governo, nº 91, sexta-feira, 17 de outubro de 1823. Rio de Janeiro: Imprensa Nacional, p. 1. João Baptista de Carvalho 17 de outubro de 1823.

${ }^{22}$ Diario Fluminense, $\mathrm{n}^{\circ}$ 132, sexta-feira, 3 de dezembro de 1824. Rio de Janeiro: Imp. Nacional, p. 1.

${ }^{23}$ Diario do Governo, $\mathrm{n}^{0}$ 101, quinta-feira, 6 de maio de 1824. Rio de Janeiro: Imprensa Nacional, p. 2.

${ }^{24}$ Diario do Governo, $\mathrm{n}^{\mathrm{o}}$ 123, terça-feira, 25 de novembro de 1823. Rio de Janeiro: Imp. Nacional, p. 4. 
rev. hist. (São Paulo), n. 171, p. 245-286, jul.-dez., 2014 http://dx.doi.org/10.11606/issn.2316-9141.rh.2014.89013
Pablo Antonio Iglesias Magalhães

Deus e o diabo na biblioteca de um cônego da Bahia: 0 inventário dos livros do padre Manoel Dendê Bus em 1836

imperial foi nomeado cônego honorário da Sé Metropolitana a 22 de setembro de 1823. Ocupando cargos eclesiásticos em Salvador, o padre teve que transferir a docência em latim para a capital da província, o que conseguiu a 28 de fevereiro de 1828. Segundo Sacramento Blake, Manoel de Freitas "foi condecorado com a medalha da campanha da independência do Brazil, para a qual cooperou efficazmente". ${ }^{25}$ Foi Blake, aliás, que fez uma grande confusão na biografia de Dendê Bus. O bibliógrafo baiano confundiu, no seu famoso dicionário oitocentista, Manoel José de Freitas Baptista Mascarenhas com Manoel José de Freitas, o gramático baiano que se intitulou Manoel de Freitas Brazileiro. Foi-nos possível, não obstante, desfazer a confusão de Blake em recente estudo sobre a gramática de Freitas Brazileiro. ${ }^{26}$ Apesar da homonimia e de ambos lecionarem gramática, são indivíduos distintos.

A Biblioteca Nacional no Rio de Janeiro conserva uma coleção de dezenove documentos, manuscritos e impressos sobre Dendê Bus não indicados na monografia escrita por Manoel de Aquino Barbosa. ${ }^{27}$ Essa coleção foi resultado de diversas petições enviadas ao governo no Rio de Janeiro. Na primeira, de 1828, o cônego da Sé da Bahia pede a sua confirmação na cadeira de gramática latina na Cidade Baixa, cargo que já exercia na condição de substituto:

Senhor

Com a mais profunda submissão Representa a Vossa Magestade Imperial Manoel Dendê Bus, Conego Honorario da Sé Metropolitana da Cidade da Bahia, que, achando-se Provido na Cadeira Publica de Grammatica e Lingua Latina do districto da mesma Cidade denominado a Praia ou Cidade Baixa, vaga por fallecimento de seu ultimo Proprietario o Padre Ignacio Jose Simões de Carvalho e Velho, pelo Governo daquella mesma Provincia em perfeita observancia do Decreto de V. M. I. em data de 15 de Novembro ultimo, e dos artigos $7^{\circ}$ e $8^{\circ}$ da Carta de Lei de 15 de Outubro, também ultimo, que aquelle Decreto faz extensivos para o provimento de taes Cadeiras; o que se mostra da própria Provisão junta, pela qual se acha o Suppl. no effectivo exercicio da mesma

${ }^{25}$ BLAKE, Augusto Alves Vitorino Sacramento. Diccionario bibliographico brazileiro, vol. 6. Rio de Janeiro: Imp. Nacional, p. 58-59. Sacramento Blake, que pouco acrescenta, duvida da existência da gramática em 1810, apontando a edição de 1820.

${ }^{26}$ MAGALHÃES, Pablo Antonio Iglesias. A palavra e o Império: Manoel de Freitas Brazileiro e a Nova grammatica ingleza e portugueza. Clio, v. 31.1, 2013. (Série História do Nordeste - UFPE)

${ }^{27}$ Manuscrito. 1824-1828. BNRJ, Seção de Manuscritos, Coleção Documentos biográficos, C-0027,023, no 001. Requerimento encaminhado ao Ministério do Império, solicitando Habito de Cristo; solicita serventia vitalícia do diploma da cadeira de gramática e língua latina; solicita ordem para tratamento da "senhoria". [S. 1.], 1824-1828. 19 documentos. Notas: Orig. Ms. O Independente Constitucional. Bahia, exemplares n 58 - março/1826 - vol. $3^{\circ} ; \mathrm{n}^{\circ} 64$ - abril/1826 - vol. $4^{\circ} ; n^{\circ} 68$ - setembro/1826 - vol. $3^{\circ} ; n^{\circ} 80$ - outubro/1826 - vol. $4^{\circ}$. 
rev. hist. (São Paulo), n. 171, p. 245-286, jul.-dez., 2014 http://dx.doi.org/10.11606/issn.2316-9141.rh.2014.89013
Pablo Antonio Iglesias Magalhães

Deus e 0 diabo na biblioteca de um cônego da Bahia: o inventário dos livros do padre Manoel Dendê Bus em 1836

Cadeira desde o dia 3 de Março ultimo; e mais ainda deve constar da parte que o Presidente daquella Provincia há de ter dado a V. M. I. nos termos do mencionado artigo $7^{\circ}$ : precisa agora para complemento da predita lei, que V. M. I. lhe faça a mercê de lhe Mandar passar o respectivo Diploma de serventia vitalícia da dita Cadeira. He por isso,

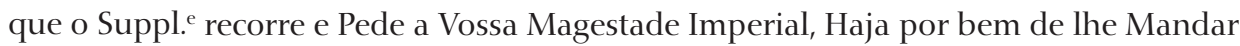
passar Carta de serventia vitalícia da dita Cadeira; no que E. R. M.

Bahia 2 de Abril de 1828

Manoel Dendê Bus

O segundo documento confirma que a petição de Dendê Bus foi apadrinhada pelo próprio presidente da província da Bahia, José Egídio Gordilho Barbuda, e antigo comandante do exército pacificador na guerra de 1822-23:

José Egidio Gordilho de Barbuda Vereador e Fidalgo Cavalleiro da Casa Imperial (...), que tendo respeito achar-se vaga por fallecimento do Padre Ignacio José Simões de Carvalho e Velho a Cadeira de Grammatica Latina da Cidade baixa, e sendo necessário, em conformidade da Resolução da Assembleia Geral Legislativa, sancionada por Decreto de 15 de Novembro do anno passado, que faz extensiva aos Professores da Lingua Latina a disposição dos Artigos segundo, setimo, oitavo, nono, decimo quarto, e decimo sexto da Carta de Lei de 15 de Outubro do dito anno a respeito dos de Primeiras Letras, provê-la em pessoa capaz, e que tenha os precisos requisitos: por concorrerem estes na do Conego Manoel Dendê Bûs, que tendo-se mostrado competentemente habilitado, e sendo examinado publicamente perante o Presidente da Provincia em Conselho, foi plenamente approvado pelos respectivos Examinadores. Por todos estes motivos, e ter jurado a Constituição Politica do Imperio, o nomeis Proffessor Publico da referida Cadeira de Grammatica Latina da Cidade baixa, da qual tomará posse, e perceberá o Ordenado á ella correspondente, depois de prestar o devido juramento na Secretaria deste Governo, e deverá requerer a Imperial Confirmação na Corte do Rio de Janeiro. Francisco José Corte Imperial a fez aos vinte seis dias do mez de Fevereiro de mil oitocentos e vinte oito. Desta dezeseis mil reis.

Jose Egidio Gordilho de Barbuda

No terceiro documento, mais curioso, o cônego requereu ao governo a confirmação do direito de ser tratado por "Sua Senhoria" por parte do vigário capitular da Sé. A resposta a suplica do cônego veio de cima, conforme publicado no periódico baiano $O$ Independente Constitucional:

Eu o Imperador Constitucional e Defensor Perpetuo do Imperio do Brazil: Faço saber, que Attendendo ao que Me representou Manoel Dendê Bus, Apresentado na Igreja Parochial de Nossa Senhora da Conceição da Praia da Cidade da Bahia: Hei por bem, que possa usar dos Habitos de Conego da Sé Metropolitana daquella Cidade, e gozar de todas as honras, que lhe forem inherentes. Este se cumprirá sendo passado pela Chancelaria das Ordens, e valerá como Carta, posto que seo effeito haja de durar mais 
rev. hist. (São Paulo), n. 171, p. 245-286, jul.-dez., 2014 http://dx.doi.org/10.11606/issn.2316-9141.rh.2014.89013
Pablo Antonio Iglesias Magalhães

Deus e o diabo na biblioteca de um cônego da Bahia: 0 inventário dos livros do padre Manoel Dendê Bus em 1836

de um anno, sem embargo da Ordenação em contrario. Rio de Janeiro vinte dois de Setembro de mil oitocentos e vinte trez, segundo da Independencia e do Imperio.

Imperador. ${ }^{28}$

O fato é que Dendê Bus circulou bem entre os homens das esferas política, militar e intelectual. $\mathrm{O}$ documento que mais revela aspectos da sua vida privada é, sem dúvida, o seu testamento, acompanhado do respectivo inventário dos seus bens. O testamento foi lavrado na cidade do Salvador, a 28 de março de 1836, observando que "São estes dous meninos herdeiros, que aqui instituo". ${ }^{29}$ Os dois meninos eram seus dois filhos, concebidos após o pai receber ordens sacras, batizados como Grato Galindo Acayaba Dendê Paraguassú (Cachoeira, 8/02/1823) e Justo Glicerio Guanadiano Dendê Caramurú (Salvador, 13/05/1825), filhos de Maria Joaquina de Oliveira. A vida sentimental do padre foi, contudo, bastante conturbada, pois a referida mulher, branca e solteira, que viveu na casa do padre até 1828, saiu de lá grávida de uma menina, batizada de Augusta, criança que o padre afirmava não ser dele. Foram as questões de foro privado, decorrentes da disputa judicial, questionando a paternidade da menina e protegendo o direito a herança dos dois meninos, que produziu o mais completo documento sobre a vida do padre Dênde Bus: o testamento, seguido de um volumoso inventário, em que está descrita sua preciosa coleção de livros. Possivelmente, uma das melhores bibliotecas privadas da Bahia na primeira metade do século XIX.

\section{A biblioteca do cônego}

Felizmente, por meio do seu inventário, podemos visualizar e reconstituir a biblioteca do padre Dendê Bus. Os livros foram arrolados entre as folhas 37 e 47 do documento, que se constitui na lista de uma das mais significativas bibliotecas particulares existentes em Salvador no período que compreende o fim do período colonial e o período regencial (1831-40). Certamente, ter-lhe-ia feito sombra a biblioteca de Francisco Agostinho Gomes que, segundo um almirante britânico, teria muitos milhares de livros, parte dos quais cedidos à Biblioteca Pública da Bahia que foi inaugurada em 1811.

\footnotetext{
${ }^{28} \mathrm{O}$ Independente Constitucional, $\mathrm{n}^{0}$ 64. Bahia, terça-feira, 19 de setembro de 1826; $O$ Independente Constitucional, $\mathrm{n}^{\circ}$ 86. Bahia, terça-feira, 17 de outubro de 1826.

${ }^{29}$ Manuscrito. 1836. Arquivo Público do Estado da Bahia. Seção Judiciária: Série Inventários: Manoel Dendê Bus (1836-7/795), maço 2432, doc. 2, fl. 4.
} 
rev. hist. (São Paulo), n. 171, p. 245-286, jul.-dez., 2014 http://dx.doi.org/10.11606/issn.2316-9141.rh.2014.89013
Pablo Antonio Iglesias Magalhães

Deus e o diabo na biblioteca de um cônego da Bahia: 0 inventário dos livros do padre Manoel Dendê Bus em 1836

No caso da biblioteca particular de Dendê Bus, foram arroladas no inventário 176 obras, que alcançaram 291 volumes, número que poderia ser ampliado se tivéssemos mais dados sobre um códice factício de sermões, que geralmente traz enfaixado diversos folhetos.

Para examinar o valor monetário da biblioteca o juiz convocou o livreiro e tipógrafo José Paulo Franco Lima. Era, sem dúvida, um dos principais comerciantes de livros em Salvador e autor de um raríssimo catálogo, impresso em Paris em 1822, com livros que disponibilizava na sua loja ao Taboão. ${ }^{30}$ Em 1835, transferiu a Typografia de Franco Lima do largo do Terreiro para a rua Direita do Palácio, atual rua Chile, casa $n^{0} 18 .^{31}$

O primeiro livro indicado no inventário é De Manu Regia Tractatu, impresso em dois volumes por Pedro Craesbeeck em 1622, tendo a segunda edição por Bourgeat em 1673 e a terceira por João Batista Lerzo, já em meados do século XVIII. É bem possível que esta última edição tenha sido a que existia na coleção de Dendê Bus. ${ }^{32}$ Não é tarefa fácil reconstituir a biblioteca do cônego ou qualquer outra por meio de um inventário preparado de forma muito desleixada e preguiçosa, como fez Franco Lima. O segundo item, por exemplo, foi descrito como "Atalas de Vanquedi" (sic); levou-me a pensar, de início, que este nome fosse uma corruptela do Atlas de Jean van Keulen (1680), impresso em Amsterdam. O atlas de Keulen já era, àquela época, decerto, uma obra estimada e de grande valor entre colecionadores e bibliófilos; possivelmente valor grande demais para as côngruas pagas a um sacerdote da Sé da Bahia. Então, concluí que "Vanquedi" seria a corruptela de Robert de Vaugondy, que publicou um atlas em Paris, muitas vezes reimpresso no século XVIII.

A historiadora Kátia Queiroz Mattoso já consultara o inventário de Dendê Bus, mas sem aprofundar a leitura do seu conteúdo. Mattoso, por exemplo, ao examinar o inventário, observou que

(...) o que impressiona, sobretudo, é a quase que completa ausência de obras teológicas. Com efeito, a literatura religiosa na biblioteca do Padre Dendê Bus, posto à parte a Bíblia, limitava-se ao Prontuário de Theologia Moral, que, apesar de não ter indicação de autoria

${ }^{30}$ NAMUR, Jean Pie. Bibliographie paleographico-diplomatico-bibliologique générale ou répertore systématique. Liége: P. J. Collardin, Imprimeur de l'Université et Libraire, 1838, trosiéme partie, p. 188. Item 1721. Catalogo dos livros portuguezes, latinos e francezes que se achão à venda em caza de M. J. Pereira Coimbra, e na loge de Jose Paulo Franco Lima ao Taboão na Bachia (sic). Paris, 1822, in-4.

31 TAVARES, Luis Guilherme Pontes (ed.). Estabelecimentos de oficinas de impressão (1833-1927). Salvador: Nehib, 2009, p. 12.

32 SILVA, Innocencio Francisco. Dccionario bibliographico portuguez, tomo III. Lisboa: Imprensa Nacional, 1860, p. 107. 
rev. hist. (São Paulo), n. 171, p. 245-286, jul.-dez., 2014 http://dx.doi.org/10.11606/issn.2316-9141.rh.2014.89013
Pablo Antonio Iglesias Magalhães

Deus e o diabo na biblioteca de um cônego da Bahia: 0 inventário dos livros do padre Manoel Dendê Bus em 1836

no inventário, certamente trata-se da obra espanhola basilar na formação espiritual dos eclesiásticos brasílicos, que teve por autor o dominicano Francisco Larraga, com diversas edições saídas dos prelos lisboetas no século XVIII. ${ }^{33}$

Mattoso ainda afirmou, por fim, que, entre os livros do cônego, "não faltavam os clássicos ingleses de Jeremy Bentham, difusor do utilitarismo, e Adam Smith, o criador do liberalismo". Equivocou-se a referida historiadora em dois pontos. Primeiro, não há a indicação de nenhum exemplar do livro de Adam Smith, apesar de já haver sido publicado em 1812 pela Impressão Régia do Rio de Janeiro, com tradução de Bento da Silva Lisboa. Segundo, há, proporcionalmente, um razoável número de obras teológicas, litúrgicas e religiosas arroladas. É possível encontrar a teologia jesuítica, presente nas obras de Paolo Segneri e Hermanni Busembaum.

Estavam presentes também os livros do padre oratoriano Antonio Pereira de Figueiredo (1725-1797), o autor com maior número de obras na biblioteca de Dendê Bus. Figueiredo foi um sacerdote português que desempenhou as atividades de latinista, historiador, canonista e teólogo. Seu trabalho mais importante foi a tradução da Bíblia da Vulgata Latina para a língua portuguesa, que durou 18 anos para ser completada. Inicialmente, foi publicado o Novo Testamento, entre 1778 e 1781, em seis volumes. O Antigo Testamento foi publicado, entre 1782 e 1790, em 17 volumes, tendo a Bíblia, ao todo, 23 volumes. Uma versão mais reduzida (em sete volumes) é considerada padrão e foi publicada em 1819. A versão da Bíblia em volume único só foi publicada em 1821. O Novo Testamento em volume único surge em 1823 e é justamente o que consta no inventário (item 159). Além desse livro valioso, existem mais quatro obras da autoria de Figueiredo (itens 52, 91, 132 e 146), de natureza linguística ou teológica.

Os livros de teologia não eram, contudo, a melhor parte da biblioteca do cônego. Eram, decerto, úteis para o ofício de um sacerdote, mas eram livros que tiveram milhares de exemplares impressos em diversas edições. Destaca-se ainda, nesse conjunto, a Colecção de bençãos eclesiásticas, curioso livro com exorcismos do ritual católico e pautas musicais de cantochão, onde estão descritas as fórmulas das bênçãos da água, do anel, dos bichos da seda, dos pertences aos bispos, das candeias, das casas, do cemitério, da comida,

\footnotetext{
33 MATTOSO, Katia M. de Queiros. Grandeurs et misères du clergé bahianais à la fin de la période coloniale (1800-1822). Histoire, économie et société, vol. 13, nº 13-2, 1994, p. 291-319; MATTOSO, Katia. Les inégalités socio-culturelles au Brésil: XVIe-XXe siècles. L'Harmattan, 2006, p. 213-214.
} 
da cruz, das espadas, dos estandartes, dos enfermos, do fogo em que se hão de queimar os sinais dos feitiços, dos frutos, do gado, das ervas, do leite, do mel, das lombrigas, dos ovos, do pão e das rosas. Encontramos também as fórmulas dos exorcismos do sal, da água, contra as aves, gafanhotos e contra a peçonha de animais venenosos.

Á área do conhecimento que se destaca na biblioteca é a de linguística. Isso não surpreende, em razão do proprietário ser professor de gramática latina. Dendê Bus apreciava os clássicos latinos, possuíndo as obras de Ovídio, Virgílio, Terêncio, Horácio, Cícero e Salústio. Também possuía bons dicionários. O cream de la cream, ao meu ver, é o dicionário de Antonio Morais Silva, que foi constantemente publicado ao longo do século XIX. Estimado desde a primeira edição (1789), alcançou 8 \$000 réis, o maior valor atribuído pelo avaliador para um item do conjunto de livros do padre. Havia dicionários franceses, espanhóis, latinos, gregos, italianos, hebraicos, holandês e até em russo.

O diabo, contudo, também estava presente na biblioteca do cônego da Sé da Bahia. Livros contendo os "abomináveis princípios franceses" eram abundantes na coleção. Os franceses da Ilustração estavam presentes por meio das obras de Fénelon, Montesquieu, Jean-Jacques Rousseau e Voltaire. ${ }^{34}$ A obra de Rousseau foi tardiamente vertida em português, mas, apesar disso, traduções de seus livros estavam presentes no inventário. Em contrapartida, Portugal conheceu um imenso número de traduções dos escritos de Voltaire, especialmente no período entre 1785 e 1820, mas, ironicamente, não encontrei nenhuma no inventário dos livros. Talvez porque fossem obras difíceis de serem achadas em virtude de confiscos feitos pela Real Mesa Censória, como ocorreu com a Henriada, de Voltaire, traduzida pelo mineiro Thomaz de Aquino Belo e Freitas em 1789.

Tanto a parenética quanto a literatura portuguesa são bastante reduzidas. De bom e estimado, havia os sermões do baiano fr. Bento da Trindade, com seis volumes, impressos em Lisboa pelo tipógrafo e livreiro Rolland. Dos poucos clássicos portugueses, estavam presentes as obras de Luís de Camões e Manuel Maria Barbosa du Bocage. A verve crítica do árcade Cruz e Silva também estava presente por meio de $O$ Hyssope, cuja primeira edição foi tirada em Paris em 1802 e logo proibida em Portugal, por ridicularizar a Igreja Católica e os resquícios feudais na mentalidade dominante. A segunda edição foi impressa em Lisboa pelo livreiro Rolland durante a ocupação

${ }^{34}$ Manuscrito. 1836. Arquivo Público do Estado da Bahia. Seção Judiciária: Série Inventários: Manoel Dendê Bus (1836-7/795), maço 2432, doc. 2. 
rev. hist. (São Paulo), n. 171, p. 245-286, jul.-dez., 2014 http://dx.doi.org/10.11606/issn.2316-9141.rh.2014.89013
Pablo Antonio Iglesias Magalhães

Deus e o diabo na biblioteca de um cônego da Bahia: 0 inventário dos livros do padre Manoel Dendê Bus em 1836

francesa e os seus exemplares à venda imediatamente apreendidos após o fim da mesma, em setembro de 1808. Aliás, em 18 de abril de 1803, fora publicado um edital do intendente de polícia, Pina Manique, que condenava a 10 anos de degredo em África quem fosse descoberto na posse de $O$ Hyssope.

Na coleção havia poucos livros impressos na Bahia, mas contava com a Alfonsiada (1818) de Lima Leitão, impresso na Tipografia de Manoel Antonio da Silva Serva. O Cornelio Nepotes também teria sido publicado por Serva em 1819, mas não foi possível encontrar algum exemplar para exame. Da Imprensa Nacional, criada em Cachoeira em 1823 e em seguida transferida para Salvador, havia a gramática inglesa (1827) do dr. Jonathas Abbott, da qual só resta um exemplar preservado, sob os cuidados do seu herdeiro Fernando Abbott Galvão. O único periódico arrolado no inventário foi o Annaes das Sciencias, das Artes e das Letras, publicado em Paris a partir de 1818 e que contava com alguns assinantes da Bahia.

Dendê Bus pode ter aproveitado sua estadia na Corte para adquirir livros fluminenses, especialmente os da Impressão Régia e de Plancher. ${ }^{35}$ Da tipografia maçônica de Plancher consta o Império do Brasil, considerado nas suas relações politicas, e commerciaes, por La Beaumelle, novamente correcto, e addicionado. Dentre os livros fluminenses do cônego, havia um exemplar do Compendio da Historia dos Estados Unidos da America, traduzido do hespanhol, por hum brasileiro, publicado na Typographia do Diario em 1827. Essa é a tradução brasileira do livro de Vicente Pazos Kanki, tão rara que só encontrei um exemplar no Instituto Geográfico e Histórico da Bahia. ${ }^{36}$

Usei alguns critérios para identificar os livros arrolados no inventário do cônego. Obviamente, todas as obras e edições eram anteriores a 1836. O principal desafio para algumas obras foi identificar a edição, pois Franco Lima não teve o cuidado de registrar, em nenhum caso, o impressor ou o ano em que a obra foi ao prelo. Em poucos itens, Lima indica o corte do exemplar, normalmente in-folio, in-4 ou in-8. O número de volumes também ajudou a identificar a edição do livro, bem como a língua em que foi publicado. Ainda assim, em parte dos livros, foi impossível identificar com precisão a edição inventariada. Nestes casos, indiquei mais de uma edição, sempre anteriores à data do inventário. No fim, temos um mosaico de possibilidades.

\footnotetext{
${ }_{35}$ Diario Fluminense, $\mathrm{n}^{\circ}$ 44, sexta-feira, 25 de fevereiro de 1825, p. 178.

${ }^{36}$ INSTITUTO HISTÓRICO E GEOGRÁFICO DA BAHIA. Catálogo de obras raras da biblioteca Rui Barbosa. Salvador: IGHB, 2013, p. 112.
} 
Seguindo as pistas dadas por Franco Lima, apuramos que a biblioteca do padre era formada por 92 livros em português, 37 em latim, 32 em francês, cinco bilíngues, três italianos, dois em inglês, um espanhol e quatro que não puderam ser identificados, somando o total de 176 obras; $52 \%$ dos livros eram em língua portuguesa, 21\% em latim, 18\% em francês, sendo que a presença de livros em inglês, italiano e espanhol soma menos de 4\% do montante. Os livros em castelhano, apesar da aproximação linguística com o português, ou por isso mesmo, nunca tiveram entrada significativa no Brasil e a coleção de Dendê Bus confirma isso. Pouquíssimos eram os impressos espanhóis na Biblioteca Pública da Bahia àquela mesma época. Não pude identificar cerca de $2 \%$ dos livros. Na transcrição do documento foi sinalizado o idioma de cada obra, indicado com as letras P (português), L (latim), F (francês), I (inglês), It (italiano), E (espanhol), D (desconhecido). Há ainda um dicionário bilíngue francês-russo e outro francês-holandês.

Para a transcrição do inventário foi mantido o texto conforme o manuscrito, com todos os equívocos e barbarismos registrados por Franco de Lima, indicando numeração das folhas entre colchetes. Dispusemos o texto original do inventário em fonte arial. Em alguns itens, fiz algumas poucas observações explicativas abaixo dos dados bibliográficos identificados.

Recuperar o catálogo da biblioteca do cônego é importante, na medida em que os historiadores do livro no Brasil não podem contar com catálogos de bibliotecas privadas. O primeiro catálogo de uma biblioteca particular no Brasil só foi publicado em 1907. A biblioteca de Dendê Bus começou a ser "juntada" ainda no período colonial e isso amplia seu significado histórico.

Manoel Dendê Bus faleceu em Salvador a 11 de maio de 1836 e foi sepultado na igreja da Conceição da Praia. A biblioteca do cônego não durou muito tempo após sua morte. Depois de uma década de tramites jurídicos, consta no volumoso processo que os bens inventariados que "fizesse arrematal-os em hasta publica, [junctam. ${ }^{\text {e }}$ com esses livros, que diz na sua declaratoria, se achão, ou existem destruidos]". ${ }^{37}$ Os herdeiros, já adultos, acusaram o seu tutor e inventariante de seu pai, Nunes Tupiniquim, de não ter conservado os livros, o que levou à destruição dos exemplares. A biblioteca do cônego Dendê Bus não existe mais fisicamente, mas o espírito daquela coleção pode ser resgatado, permitindo aos bibliógrafos e historiadores aprofundarem as

${ }^{37}$ Manuscrito. 1836. Apeb. Seção Judiciária: Série Inventários: Manoel Dendê Bus (1836-7/795), maço 2432, doc. 2, fl. 129. 
rev. hist. (São Paulo), n. 171, p. 245-286, jul.-dez., 2014 http://dx.doi.org/10.11606/issn.2316-9141.rh.2014.89013
Pablo Antonio Iglesias Magalhães

Deus e o diabo na biblioteca de um cônego da Bahia: 0 inventário dos livros do padre Manoel Dendê Bus em 1836

investigações sobre os hábitos de leitura e a circulação do conhecimento num período conturbado da História do Brasil e da Bahia.

\section{O inventário dos livros - documento}

\section{[fl. 37] Continuação do inventário}

No primeiro dia do mez de Oitubro (sic) de mil oitocentos e trinta e seis annos nesta Cidade da Bahia e casa da residencia do Doutor Juiz dos Orfãos Amancio João Pereira de Andrade compareceo José Paulo Franco Lima, livreiro, ao qual o mesmo Juiz deferio o juramento dos Sanctos Evangelhos, recomendando lhe que com boa consciência visse, e examinasse os livros do finado, Vigario Manoel Dendê Bus, e como Avaliadores do auditório, Ihe desse os justos valores, que entendessem sem dolo ou malicia sob pena da Ley: e recebendo elle o juramento, assim o prometteo cumprir. De que fiz este termo, em que assignarão. Eu José Olympio Gomes de Souza Escrivão o escrevi.

Dr. Per. ${ }^{a}$ de And. ${ }^{\text {e José Paulo Franco Lima }}$

[fl.37v]

\section{Livros}

\begin{tabular}{|c|c|c|}
\hline $\begin{array}{l}N^{\circ} / \\
\text { IDIOMA }\end{array}$ & $\begin{array}{l}\text { Transcrição } \\
\text { inventário }\end{array}$ & Dados bibliográficos identificados \\
\hline $\begin{array}{l}1 \\
P\end{array}$ & $\begin{array}{l}\text { Hum ditto de Pereira de } \\
\text { Manu Regia in folio avalia- } \\
\text { do em dois mil e quatrocen- } \\
\text { tos reis } 2 \$ 400\end{array}$ & $\begin{array}{l}\text { CASTRO, Gabrielis Pereirae de. Tractatus de Manu Re- } \\
\text { gia: Editio novissima auctior, infinitis pene mendis, quibus } \\
\text { scatebat ad amussim expurgata cum novis additionibus et } \\
\text { duplici indice locupletissimo. Ulyssipone: Ex Typis Joannis } \\
\text { Baptistae Lerzo, } 1742,2 \text { vol., } 30 \mathrm{~cm} \text {. }\end{array}$ \\
\hline $\begin{array}{l}2 \\
F\end{array}$ & $\begin{array}{l}\text { Hum Atalas (sic) de Van- } \\
\text { quedi in folio avaliado em } \\
\text { tres mil e duzentos reis } \\
3 \$ 200\end{array}$ & $\begin{array}{l}\text { VAUGONDY, Robert. Atlas universel / Robert de Vaugon- } \\
\text { dy fils, C. F. Delamarche. Corrigé et augmenté de la carte } \\
\text { de la République Française divisée en departemens. Pa- } \\
\text { ris: chez Delamarche, } 1797 \text {. }\end{array}$ \\
\hline $\begin{array}{l}3 \\
P\end{array}$ & $\begin{array}{l}\text { Regras methodicas para se } \\
\text { apprender a escrever, por } \\
\text { Joaquim José Ventura hum } \\
\text { volume por quatro mil e oi- } \\
\text { tocentos reis } 4 \$ 800\end{array}$ & $\begin{array}{l}\text { SILVA, Joaquim José Ventura da. Regras methodicas } \\
\text { para se aprender a escrever o caracter da letra ingleza, } \\
\text { acompanhadas de humas noções de arithmetica. Lisboa: } \\
\text { na Officina de Simão Thaddeo Ferreira, } 1803,273 \text {, [3] p., } \\
18 \mathrm{~cm} .2^{a} \text { ed. accrescentada, correcta e augmentada. Lis- } \\
\text { boa: Impressão Régia, } 1819,370 \text { p., } 18 \mathrm{~cm} \text {. }\end{array}$ \\
\hline
\end{tabular}


rev. hist. (São Paulo), n. 171, p. 245-286, jul.-dez., 2014 http://dx.doi.org/10.11606/issn.2316-9141.rh.2014.89013
Pablo Antonio Iglesias Magalhães

Deus e o diabo na biblioteca de um cônego da Bahia: 0 inventário dos livros do padre Manoel Dendê Bus em 1836

\begin{tabular}{|c|c|c|}
\hline $\begin{array}{l}4 \\
P\end{array}$ & $\begin{array}{l}\text { Volume da Independencia } \\
\text { do Imperio do Brasil por } \\
\text { Beauchamp avaliado por } \\
\text { trezentos e vinte reis } \$ 320\end{array}$ & $\begin{array}{l}\text { BEAUCHAMP, Alphonse de. Independencia do Imperio do } \\
\text { Brasil, apresentada aos monarchas europeos por mr. Beau- } \\
\text { champ. Rio de Janeiro: na Typographia Nacional, } 1824,32 \\
\text { p., } 29,5 \mathrm{~cm} \text {. }\end{array}$ \\
\hline $\begin{array}{l}5 \\
\mathrm{~L} / \mathrm{F}\end{array}$ & $\begin{array}{l}\text { De Ouvidio (sic) quatro vo- } \\
\text { lumes em quarto por seis- } \\
\text { centos e quarenta reis } \$ 640\end{array}$ & $\begin{array}{l}\text { Les métamorphoses d'Ovide, en latin \& en françois, de la } \\
\text { traduction de M. l'Abbé Banier, avec des explications histo- } \\
\text { riques, \& des figures gravées sur les desseins des meilleurs } \\
\text { Peintres françois, par les soins des sieurs Le Mire \& Basan. } \\
\text { Paris: Pissot, } 1767,4 \text { vol., in- } 4 \text {. } \\
\text { Ovide. Les Metamorphoses, trad. par J. - G. Dubois Fon- } \\
\text { tanelle, nouv. édit. augmentée de notes avec le text lat. } \\
\text { Paris, } 1802 \text {, Ovide, } 4 \text { vol., in-8. Traduction en vers des } \\
\text { Métamorphoses d'Oivide, par F. de Saint-Ange. Paris: } \\
\text { Desray, } 1808,4 \text { vol., in-8. }\end{array}$ \\
\hline $\begin{array}{l}6 \\
P\end{array}$ & $\begin{array}{l}\text { Duas broxuras dos Annaes } \\
\text { das sciencias, das Artes } \\
\text { e Letras por seiscentos e } \\
\text { quarenta } r^{\text {s }} \$ 640\end{array}$ & $\begin{array}{l}\text { Annaes das sciencias, das artes e das letras / por huma } \\
\text { sociedade de portuguezes residentes em Paris. Paris: } \\
\text { imp. por A. Bobée, 1818; Paris: imp. por A. Bobée, 1818- } \\
\text { 22, } 16 \text { tomos em } 8 \text { vol., } 20 \mathrm{~cm} \text {. }\end{array}$ \\
\hline $\begin{array}{l}7 \\
P\end{array}$ & $\begin{array}{l}\text { Escola Brasileira duas bro- } \\
\text { xuras avaliadas ambas por } \\
\text { oitocentos reis } \$ 800 \text { [fl. 38] }\end{array}$ & $\begin{array}{l}\text { LISBOA, José da Silva. Escola brasileira, ou instrucção util } \\
\text { á todas as classes, extrahida da Sagrada Escriptura para } \\
\text { uso da mocidade, por José da Silva Lisboa. Rio de Janeiro: } \\
\text { Typographia de P. Plancher-Seignot, } 1827,2 \text { vol., } 21 \mathrm{~cm} \text {. }\end{array}$ \\
\hline & $12 \$ 800$ & \\
\hline $\begin{array}{l}8 \\
P\end{array}$ & $\begin{array}{l}\text { Humas broxuras de En- } \\
\text { tretenimentos de Phocion } \\
\text { avaliadas por seiscentos e } \\
\text { quarenta reis } \$ 640\end{array}$ & $\begin{array}{l}\text { COELHO, José Mendes da Costa. Tradução. Entreteni- } \\
\text { mentos de Phocion, sobre a relação da moral com a po- } \\
\text { litica: traduzidos do grego em francez. com observações } \\
\text { pelo abbade de Mably, e em linguagem vulgar. Bahia: Typ. } \\
\text { Imperial e Nacional, } 1826,4^{\circ} \text { de XII, } 100 \text { p. }\end{array}$ \\
\hline $\begin{array}{l}9 \\
P\end{array}$ & $\begin{array}{l}\text { Folheto dos sofismas anar- } \\
\text { quicos por Bentham por } \\
\text { quatrocentos e oitenta } r .^{\text {s }} \\
\$ 480\end{array}$ & $\begin{array}{l}\text { BENTHAM, Jeremy. Sophismas anarchicos: exame critico } \\
\text { de diversas declarações dos direitos do homem, e do cida- } \\
\text { dão / por mr. Bentham; traduzido em linguagem e offerecido } \\
\text { a Assembléa Geral, Constituinte, e Legislativa do Imperio do } \\
\text { Brazil, por R. P. B. Rio de Janeiro: Typographia Nacional, } \\
1823,71 \text { p., } 19 \mathrm{~cm} \text {. }\end{array}$ \\
\hline $\begin{array}{l}10 \\
P\end{array}$ & $\begin{array}{l}\text { Compendio da historia dos } \\
\text { Estados Unidos por quatro- } \\
\text { centos e oitenta reis } \$ 480\end{array}$ & $\begin{array}{l}\text { Compendio da historia dos Estados Unidos da America, } \\
\text { traduzidos do hespanhol por hum brasileiro. Rio de Janei- } \\
\text { ro: na Typographia do Diario, } 1827,164 \text { p. }\end{array}$ \\
\hline $\begin{array}{l}11 \\
F\end{array}$ & $\begin{array}{l}\text { Seis volumes da Colleção } \\
\text { das Constituiçoens, Cartas } \\
\text { e Leis fundamentaes nos } \\
\text { Povos da Europa, e das } \\
\text { duas Americas por oito mil } \\
\text { reis } 8 \$ 000\end{array}$ & $\begin{array}{l}\text { Collection des Constitutions, chartes et lois fondamenta- } \\
\text { les des peuples de l'Europe et des deux Amériques; [Texto } \\
\text { impresso]: avec des precis offrant l'histoire des libertés et } \\
\text { des institutions politiques chez les nations modernes; et } \\
\text { une table alphabétique raisonnée des matières; par M. M. } \\
\text { P.[ierre] A.[rmand] Dufau; J.[ean]- B. [aptiste] Duvergier et } \\
\text { J.[oseph] Guadet, avocats à la Cour royale de Paris. Pa- } \\
\text { ris: J. L. Chanson, Imprimeur-Libraire, Éditeur, 1821-23, } 6 \\
\text { vol., } 8^{\circ}, 20 \mathrm{~cm} \text {. }\end{array}$ \\
\hline
\end{tabular}


rev. hist. (São Paulo), n. 171, p. 245-286, jul.-dez., 2014 http://dx.doi.org/10.11606/issn.2316-9141.rh.2014.89013
Pablo Antonio Iglesias Magalhães

Deus e o diabo na biblioteca de um cônego da Bahia: 0 inventário dos livros do padre Manoel Dendê Bus em 1836

\begin{tabular}{|c|c|c|}
\hline $\begin{array}{l}12 \\
\mathrm{~L}\end{array}$ & $\begin{array}{l}\text { Horacio com interpolaço- } \\
\text { ens e Notas avaliado por } \\
\text { mil e seiscentos reis } 1 \$ 600\end{array}$ & $\begin{array}{l}\text { Quinti Horatii Flacci Opera, interpretatione et notis illustra- } \\
\text { vit Ludovicus Desprez. Huic editioni accessere Vita Horatii, } \\
\text { cum Dacerii notis, ejusdem Chronologia Horatiana et prae- } \\
\text { fatio de satyra Horatiana. Editio nona. Londini: imprens. J. } \\
\text { J. et P. Knapton, } 1734 \text {. } \\
\text { Há um significativo número de edições de Horácio com } \\
\text { "interpretação e notas", feitas entre o século XVII e o XIX. }\end{array}$ \\
\hline $\begin{array}{l}13 \\
P\end{array}$ & $\begin{array}{l}\text { Alfonsiada Poema heroico } \\
\text { avaliado por oitocentos reis } \\
\$ 800\end{array}$ & $\begin{array}{l}\text { LEITÃO, Antonio José Osório de Pina. Alfonsiada: poema } \\
\text { heroico da fundação da monarquia portugueza pelo senhor } \\
\text { rei d. Alfonso Henriques. Bahia: Typ. Manuel Antonio da } \\
\text { Silva Serva, } 1818,278 \text { p., [3] retr., } 21 \mathrm{~cm} \text {. }\end{array}$ \\
\hline $\begin{array}{l}14 \\
P\end{array}$ & $\begin{array}{l}\text { Instituiçoens oratorias de } \\
\text { Quintiliano traduzidas e } \\
\text { ilustradas por Jeronimo } \\
\text { Soares dois volumes em } \\
\text { quarto por mil novecentos e } \\
\text { vinte reis } 1 \$ 920\end{array}$ & $\begin{array}{l}\text { BARBOSA, Jeronimo Soares. Instituiçoens oratorias de M. } \\
\text { Fabio Quintiliano: escolhidas dos secs XII livros, traduzidas } \\
\text { em linguagem, e illustradas com notas criticas, historicas, e } \\
\text { rhetoricas, para uso dos que aprendem: ajuntão-se no fim } \\
\text { as peças originaes de eloquencia, citadas por Quintiliano } \\
\text { no corpo destas instituiçoens / M. Fabio Quintiliano; selec- } \\
\text { ção, trad. e comentario Jeronymo Soares Barboza. Coim- } \\
\text { bra: Imprensa Real da Universidade, } 1788,2 \text { vol., } 21 \mathrm{~cm} \text {. }\end{array}$ \\
\hline & $26 \$ 720$ & \\
\hline $\begin{array}{l}15 \\
P\end{array}$ & $\begin{array}{l}\text { Obras completas de [fl. } \\
38 \mathrm{v} \text { ] de Felinto Elysio seis } \\
\text { volumes faltando cinco } \\
\text { avaliados por quatro mil e } \\
\text { oitocentos reis } 4 \$ 800\end{array}$ & $\begin{array}{l}\text { ELİSIO, Filinto, [NASCIMENTO, Francisco Manoel do]. } \\
\text { Obras completas de Filinto Elysio. } 2^{\mathrm{a}} \text { ed. emendada e } \\
\text { accrescentada com muitas obras inéditas e com o retrato } \\
\text { do autor. Paris: Officina de A. Bobée, } 1817-1819,11 \text { vol. }\end{array}$ \\
\hline $\begin{array}{l}16 \\
P\end{array}$ & $\begin{array}{l}\text { Huma Arte Poética de Ho- } \\
\text { racio Traduzida em prosa } \\
\text { por Fonseca avaliada por } \\
\text { oitocentos reis, alias, por } \\
\text { novecentos e sessenta reis } \\
\$ 960\end{array}$ & $\begin{array}{l}\text { Arte poetica de Q. Horacio Flacco, epistola aos Pisões / } \\
\text { trad., notas por José Pedro da Fonseca. Lisboa: Off. de } \\
\text { Simão Thaddeo Ferreira, } 1790,1 \text { vol., } 20 \mathrm{~cm} \text {. }\end{array}$ \\
\hline $\begin{array}{l}17 \\
P\end{array}$ & $\begin{array}{l}\text { Elementos de Poetica tira- } \\
\text { dos de vários Authores pelo } \\
\text { mesmo Fonseca avaliado } \\
\text { por seiscentos e quarenta } \\
\text { reis } \$ 640\end{array}$ & $\begin{array}{l}\text { FONSECA, Pedro José da. Elementos de poetica, tirados } \\
\text { de Aristoteles, de Horacio e dos mais celebres modernos } / \\
\text { Pedro José da Fonseca. Lisboa: Imp. de Miguel Manescal } \\
\text { da Costa, } 1765 . \\
\text { Segunda edição. Lisboa: na Typografia Rollandiana, } \\
\text { 1781. } 3^{a} \text { ed. Lisboa: Typ. Rollandiana, } 1804 \text {. }\end{array}$ \\
\hline $\begin{array}{l}18 \\
P\end{array}$ & $\begin{array}{l}\text { Hum volume Poetica de } \\
\text { Horacio Traduzida em ver- } \\
\text { so por seiscentos e quaren- } \\
\text { ta } .^{.} \$ 640\end{array}$ & $\begin{array}{l}\text { FLACO, Q. Horacio. Arte poetica: epistola aos pisões tra- } \\
\text { duzida em verso portuguez por Antonio José de Lima Lei- } \\
\text { tão. } 1^{\mathrm{a}} \text { ed. Bahia: Typ. de Manoel Antonio da Silva Serva, } \\
1818,58 \text { p., } 21 \mathrm{~cm} .2^{\mathrm{a}} \text { ed. Lisboa: Imp. Manoel Joseph da } \\
\text { Cruz, } 1827,31 \mathrm{p.}, 15 \mathrm{~cm} \text {. }\end{array}$ \\
\hline $\begin{array}{l}19 \\
P\end{array}$ & $\begin{array}{l}\text { Memorias históricas do Rio } \\
\text { de Janeiro por Pizarro ava- } \\
\text { liado por oito mil reis } 8 \$ 000\end{array}$ & $\begin{array}{l}\text { ARAÚJO, José de Sousa Pizarro e. Memorias historicas } \\
\text { do Rio de Janeiro e das provincias annexas à jurisdição } \\
\text { do vice-rei do Estado do Brasil. Rio de Janeiro: na Impr. } \\
\text { Régia, } 1820-1822,9 \text { vol., } 20 \mathrm{~cm} \text {. }\end{array}$ \\
\hline
\end{tabular}


rev. hist. (São Paulo), n. 171, p. 245-286, jul.-dez., 2014 http://dx.doi.org/10.11606/issn.2316-9141.rh.2014.89013
Pablo Antonio Iglesias Magalhães

Deus e o diabo na biblioteca de um cônego da Bahia: 0 inventário dos livros do padre Manoel Dendê Bus em 1836

\begin{tabular}{|c|c|c|}
\hline $\begin{array}{l}20 \\
P\end{array}$ & $\begin{array}{l}\text { Huma Corografia Brasilica } \\
\text { avaliada por tres mil reis } \\
3 \$ 000\end{array}$ & $\begin{array}{l}\text { CAZAL, Manuel Ayres de. Corografia brazilica, ou Rela- } \\
\text { ção historico-geografica do reino do Brazil / composta e } \\
\text { dedicada a sua magestade fidelissima por hum presbitero } \\
\text { secular do gram priorado do Crato. Rio de Janeiro: na Im- } \\
\text { pressão Regia, } 1817,2 \text { vol., } 23 \mathrm{~cm} \text {. Vol, 1: [8], } 420 \text { p., vol. } \\
\text { 2: [4], } 379 \text {, [5] p. }\end{array}$ \\
\hline \multirow[t]{2}{*}{$\begin{array}{l}21 \\
\mathrm{~L}\end{array}$} & $\begin{array}{l}\text { Dois Gradus ad Parnasum } \\
\text { avaliados por dois mil e } \\
\text { digo por mil duzentos e oi- } \\
\text { tenta r.s } 1 \$ 280\end{array}$ & $\begin{array}{l}\text { SINTENIS, Carolo Henrico [Karl Heinrich Sintenis]. Gradus } \\
\text { ad parnassum, sive, promtuarium prosodicum, syllabarum } \\
\text { latinarum quantitatem hujusque regulas praecipuas, et } \\
\text { synonymorum, epithetorum, phrasium, descriptionum ac } \\
\text { comparationum poeticarum copiam continens, et in usum } \\
\text { juventutis scholasticae. Editum a M. Carolo Henrico Sinte- } \\
\text { nis. Pars prior und pars posterior. Züllichau: Darnmannii, } \\
1816,2 \text { vol., XXVIII, } 436,523 \text { p. } \\
2^{a} \text {. ed. datada de } 1822 \text {. }\end{array}$ \\
\hline & $46 \$ 040$ & \\
\hline $\begin{array}{l}22 \\
P\end{array}$ & $\begin{array}{l}\text { Hum volume do Imperio do } \\
\text { Brasil por La Beau [fl. 39] } \\
\text { Melli avaliado por seiscen- } \\
\text { tos e quarenta reis } \$ 640\end{array}$ & $\begin{array}{l}\text { LA BEAUMELLE, Victor Laurent Suzanne Moise Angliviel } \\
\text { de. O Império do Brasil, considerado nas suas relações } \\
\text { politicas, e commerciaes, por La Beaumelle, novamente } \\
\text { correcto, e addicionado. Rio de Janeiro: na Typographia } \\
\text { de Plancher, 1824, [7] f., [11]-278 p., [1] f., } 19,5 \mathrm{~cm} \text {. }\end{array}$ \\
\hline $\begin{array}{l}23 \\
1\end{array}$ & $\begin{array}{l}\text { Esquice (sic) da Revolução } \\
\text { da America Hespanhola } \\
\text { avaliado em seiscentos e } \\
\text { quarenta reis } \$ 640\end{array}$ & $\begin{array}{l}\text { [NILES, John Milton]. Sketch of the history of Spanish } \\
\text { America to the revolution. In: A view of South America and } \\
\text { Mexico, comprising their history, the political condition, } \\
\text { geography, agriculture, commerce, \&c. of the republics of } \\
\text { Mexico, Guatemala, Columbia, Peru, the United provinces } \\
\text { of South America and Chili, with a complete history of the } \\
\text { revolution in each of these independent states. By a citi- } \\
\text { zen of the United States. Nova York: H. Huntington, Jr., } \\
1825,2 \text { vol. illus., } 18 \mathrm{~cm} \text {. Vol. 1: [2], } 223 p \text {.; vol. } 2,263 \text { p. } \\
\text { Esse texto foi reimpresso com o nome do autor em } 1837 . \\
\text { A edição de } 1825 \text { apresenta um retrato de Simón Bolivar. }\end{array}$ \\
\hline $\begin{array}{l}24 \\
P\end{array}$ & $\begin{array}{l}\text { Hum Cornelio Nepote ava- } \\
\text { liado em seiscentos e qua- } \\
\text { renta reis } \$ 640\end{array}$ & $\begin{array}{l}\text { NEPOTES, Cornélio. Cornelio Nepotes. Bahia: Typ. de } \\
\text { Manoel Antonio da Silva Serva, } 1819 \text {. } \\
\text { Essa obra foi anunciada na Idade d'Ouro na edição de } \\
11.05 .1819 \text { in- } 8^{\circ} \text { grande, por } 1 \$ 280 \text { reís. Não foi encontra- } \\
\text { do exemplar para consulta. }\end{array}$ \\
\hline $\begin{array}{l}25 \\
F\end{array}$ & $\begin{array}{l}\text { Tablettes chronologicas de } \\
\text { Historia universal avaliadas } \\
\text { por mil e seiscentos reis } \\
1 \$ 600\end{array}$ & $\begin{array}{l}\text { LENGLET DU FRESNOY, Nicolas. Tablettes chronologi- } \\
\text { ques de l'histoire universelle sacrée et prophane, eccle- } \\
\text { siastique et civile depuis la creation du monde jusqu'a l'an } \\
\text { 1743: avec reflexions sur l'ordre qu'on doit tenir \& sur les } \\
\text { ouvrages necessaires pour l'etude de l'histoire / par M. } \\
\text { L'Abbé Lenglet du Fresnoy. Paris: chez De Bure, Ganeau, } \\
\text { 1744, } 2 \text { t. em } 2 \text { vol., } 18 \mathrm{~cm} \text {. }\end{array}$ \\
\hline $\begin{array}{l}26 \\
P\end{array}$ & $\begin{array}{l}\text { Hum Diccionario Italiano } \\
\text { e Portuguez avaliado em } \\
\text { seis mil e quatrocentos reis } \\
6 \$ 400\end{array}$ & $\begin{array}{l}\text { SÁ, Joaquim José da Costa e. Diccionario italiano e portu- } \\
\text { guez / Joaquim José da Costa e Sá. Lisboa: Regia Offici- } \\
\text { na Typographica, 1773-1774, } 2 \text { vol., in-4, } 30 \mathrm{~cm} \text {. }\end{array}$ \\
\hline
\end{tabular}


rev. hist. (São Paulo), n. 171, p. 245-286, jul.-dez., 2014 http://dx.doi.org/10.11606/issn.2316-9141.rh.2014.89013
Pablo Antonio Iglesias Magalhães

Deus e o diabo na biblioteca de um cônego da Bahia: 0 inventário dos livros do padre Manoel Dendê Bus em 1836

\begin{tabular}{|c|c|c|}
\hline $\begin{array}{l}27 \\
L\end{array}$ & $\begin{array}{l}\text { Hum magnum Lexicon ava- } \\
\text { liado por tres mil e duzentos } \\
\text { reis } 3 \$ 200\end{array}$ & $\begin{array}{l}\text { CABRAL, Manoel. Magnum lexicon latinum et lusitanum. } \\
\text { Olisipone: Typis Regiae Officinae, } 1789.1 \text { vol., in-fol. } \\
\text { Teve segunda edição: } \\
\text { Magnum lexicon latinum et lusitanum / editio altera opera } \\
\text { et studio. Fr. Emmanuelis Pinii Cabralii. Ulyssipone: Typis } \\
\text { Simonis Thaddaei Ferreira, } 1802 \text {. }\end{array}$ \\
\hline $\begin{array}{l}28 \\
P\end{array}$ & $\begin{array}{l}\text { Hum dito Portuguez de Mo- } \\
\text { raes dois volumes avaliado } \\
\text { em oito mil reis } 8 \$ 000\end{array}$ & $\begin{array}{l}\text { SILVA, Antonio de Moraes. Diccionario da lingua portu- } \\
\text { gueza recopilado dos vocabulários impressos até agora... } \\
\text { / Antonio de Moraes Silva. 2a ed. novamente emendado e } \\
\text { muito accrescentado. Lisboa: Typ. Lacerdina, 1813, } 2 \text { vol., } \\
27 \mathrm{~cm} \text {. 3a ed. Lisboa: Borel Borel e Companhia, } 1823 \text {. } \\
\text { A primeira edição data de 1789, feita na Oficina de Simão } \\
\text { Thaddeo Ferreira. }\end{array}$ \\
\hline \multirow[t]{2}{*}{$\begin{array}{l}29 \\
F\end{array}$} & $\begin{array}{l}\text { Hum ditto Francez e Portu- } \\
\text { guez avaliado em seis mil } \\
\text { e quatrocentos reis } 6 \$ 400 \\
\text { [fl.39v] }\end{array}$ & $\begin{array}{l}\text { Dictionnaire français, et portugais plus complet que tous } \\
\text { ceux qui ont paru jusqu'à présent pour l'instruction de la } \\
\text { jeunesse portugaise. Lisboa: chez Georges Rey et Com- } \\
\text { pagnie, Libraires do Poço Novo, } 1769 \text {, in-8, } 20 \times 15 \mathrm{~cm} \text {. }\end{array}$ \\
\hline & $76 \$ 760$ & \\
\hline $\begin{array}{l}30 \\
L\end{array}$ & $\begin{array}{l}\text { Graecum Lexicon Manuale } \\
\text { por tres mil e seiscentos } \\
\text { reis } 3 \$ 600\end{array}$ & $\begin{array}{l}\text { HEDERICH, Benjamin. Graecum lexicon manuale, primùm } \\
\text { a Benjamine Hederico institutum: dein post repetitas Sam. } \\
\text { Patricii curas, auctum myriade amplius verborum: postre- } \\
\text { mo innumeris vitiis repurgatum, plurimisque novis signifi- } \\
\text { catibus verborum locupletatum cura lo. Augusti Ernesti: et } \\
\text { nunc iterum recensitum, et quamplurimum in utraque par- } \\
\text { te auctum a T. Morell. Editio nova, prioribus longè emen- } \\
\text { datior. Londres: Excudit H. S. Woodfall, impensis, J. F. \& } \\
\text { C. Rivington, T. Longman, B. Law, T. Pote, J. Johnson, } \\
\text { 1790, viii, } 828 \text { p., in- } 4^{\circ} \text {. } \\
\text { 2.ed, } 1825.987 \text { p., } 28 \mathrm{~cm} \text {, in- } 4^{\circ} \text {. }\end{array}$ \\
\hline $\begin{array}{l}31 \\
F\end{array}$ & $\begin{array}{l}\text { Hum Diccionario portatil da } \\
\text { pronuncia Franceza e italia- } \\
\text { na avaliado por mil duzen- } \\
\text { tos e oitenta reis } 1 \$ 280\end{array}$ & $\begin{array}{l}\text { BARBERI, J. PH. Dictionnaire portatif français-italien, et } \\
\text { italien-français, composé sur la dernière edition du voca- } \\
\text { bulaire de l'Académie della Crusca, sur celui d'Alberti, et } \\
\text { sur les meilleurs dictionnaires français, tels que celui de } \\
\text { l'Académie française, de Laveaux, de Boiste etc. et rédigé } \\
\text { sur le nouveau plan, avec l'accent prosodique sur tout les } \\
\text { mots italiens. Paris: J. P. Aillaud, 1822, } 2 \text { vols., in-4, 9, (1), } \\
499 \text { (1 branco); } 683 \text { (1 branco) p. }\end{array}$ \\
\hline $\begin{array}{l}32 \\
F\end{array}$ & $\begin{array}{l}\text { Hum ditto ditto (sic) de pro- } \\
\text { nuncia italiana e Franceza } \\
\text { por mil duzentos e oitenta } \\
\text { r.s }^{\text {s }} \$ 280\end{array}$ & $\begin{array}{l}\text { Penso tratar-se do segundo volume da obra acima } \\
\text { referenciada. }\end{array}$ \\
\hline $\begin{array}{l}33 \\
F\end{array}$ & $\begin{array}{l}\text { Novo Diccionario Geografi- } \\
\text { co por Voigeu avaliado por } \\
\text { mil e seiscentos reis } 1 \$ 600\end{array}$ & $\begin{array}{l}\text { VOSGIEN. Nouveau dictionnaire géographique ou des- } \\
\text { cription de toutes les parties du Monde par Vosgien. Pa- } \\
\text { ris: chez Saintin, de l'imprimerie Lanoe, 1813, in-12, } 4 \text { ff, } \\
\text { IV, } 319,231,1 \mathrm{ff} .\end{array}$ \\
\hline $\begin{array}{l}34 \\
P\end{array}$ & $\begin{array}{l}\text { Hum ditto histórico por mil e } \\
\text { seiscentos reis } 1 \$ 600\end{array}$ & $\begin{array}{l}\text { DEUS, João de. Diccionario historico, juridico, e theologi- } \\
\text { co, que contem as peças mais interessantes pertencentes } \\
\text { á historia ecclesiastica, á jurisprudencia, e á theologia / fr. } \\
\text { João Deos. Porto: Typ. de Antonio Alvarez Ribeiro, 1804, } \\
2 \text { vol., } 16 \mathrm{~cm} \text {. }\end{array}$ \\
\hline
\end{tabular}


rev. hist. (São Paulo), n. 171, p. 245-286, jul.-dez., 2014 http://dx.doi.org/10.11606/issn.2316-9141.rh.2014.89013
Pablo Antonio Iglesias Magalhães

Deus e o diabo na biblioteca de um cônego da Bahia: 0 inventário dos livros do padre Manoel Dendê Bus em 1836

\begin{tabular}{|c|c|c|}
\hline $\begin{array}{l}35 \\
P\end{array}$ & $\begin{array}{l}\text { Hum ditto poetico por Can- } \\
\text { dido Lusitano avaliado por } \\
\text { mil e seiscentos reis } 1 \$ 600\end{array}$ & $\begin{array}{l}\text { LUSITANO, Cândido [FREIRE, Francisco José]. Dicciona- } \\
\text { rio poetico, para uso dos que principião a exercitarse na } \\
\text { poesia portugueza: obra igualmente util ao orador princi- } \\
\text { piante / seu author Candido Lusitano. Lisboa: na Offic. Pa- } \\
\text { triarcal de Francisco Luiz Ameno, } 1765,2 \text { vol., } 4^{\circ}, 21 \mathrm{~cm} \text {. } \\
\text { Segunda edição correcta. Lisboa: Of. Simão Thaddeo } \\
\text { Ferreira, } 1794,2 \text { tom. em } 1 \text { vol., } 21 \mathrm{~cm} \text {. } \\
\text { 3a imp., Lisboa: Imp. Regia, } 1820,2 \text { vols. enc. em } 1,21 \mathrm{~cm} \text {. }\end{array}$ \\
\hline $\begin{array}{l}36 \\
P\end{array}$ & $\begin{array}{l}\text { Hum ditto abbreviado da } \\
\text { Fabula avaliado por mil e } \\
\text { seiscentos reis } 1 \$ 600\end{array}$ & $\begin{array}{l}\text { Dicionário abreviado da fábula para intelligencia dos po- } \\
\text { etas dos paineis, e das estatuas cujos argumentos são } \\
\text { tirados da historia poetica por mr Chompré. Lisboa: Régia } \\
\text { Of. Tipográfica, } 1779 \text {. Teve mais cinco edições em Lisboa: } \\
\text { Typ. da Academia Real das Sciencias, 1785; Regia Offi- } \\
\text { cina typografica,1789; Regia Officina Typ, 1793; Off. de } \\
\text { Simão Thaddeo Ferreira, 1807; Tip. da Academia Real de } \\
\text { Ciências. } 1819 \text {. }\end{array}$ \\
\hline $\begin{array}{l}37 \\
L\end{array}$ & $\begin{array}{l}\text { Johannis Buxtorfie Lexicon } \\
\text { Hebraicum avaliado por } \\
\text { quatrocentos e oitenta reis } \\
\$ 480\end{array}$ & $\begin{array}{l}\text { BUXTORFI, Johann. Lexicon Hebraicum et Chaldaicum } \\
\text { complectens; Omnes voces, tam primæ quam derivatæ } \\
\text { quæ in Sacris Bibliis, Hebræa \& ex parte Chaldæa lingua } \\
\text { scriptis, extant: interpretationis fide, exemplorum Biblico- } \\
\text { rum copia, locirum pluminorum difficilium ex variis He- } \\
\text { bræorum Commentariis explicatione, auctum \& ilustratum: } \\
\text { Accessit lexicon breve Rabbinic-Philosophicum, commu- } \\
\text { mora vocabula continens, quæ in commentariis passim } \\
\text { occurrunt. Cum indice vocum Latino. Basileia: Typis Con- } \\
\text { radi Waldkirchi. Imprensis Ludovici Konig, } 1607 \text {. } \\
\text { Pude ver reedições de } 1615,1621,1663,1654,1676 \text {, } \\
1689,1698,1735 \text {. }\end{array}$ \\
\hline $\begin{array}{l}38 \\
P / F\end{array}$ & $\begin{array}{l}\text { Novo Diccionario de Poche } \\
\text { Francez, e Portuguez por } \\
\text { mil e seiscentos reis } 1 \$ 600\end{array}$ & $\begin{array}{l}\text { Novo diccionario portatil portuguez e francez; Nouveau } \\
\text { dictionnaire de poche français-portugais. Nouvelle éd., } \\
\text { revue et corrigée. Paris: Rey et Gravier; Lisboa: Pierre et } \\
\text { Georges Rey, } 1820 \text {, VII, } 429 \text {, IV, } 365 \text { p. a } 3 \text { colun., } 15 \mathrm{~cm} \text {. }\end{array}$ \\
\hline & $91 \$ 000$ & \\
\hline $\begin{array}{l}39 \\
P\end{array}$ & $\begin{array}{l}\text { [fl.40] Diccionario dos Eclip- } \\
\text { ses (sic) por Manoel Ro- } \\
\text { drigues Maya avaliado por } \\
\text { trezentos e vinte reis } \$ 320\end{array}$ & $\begin{array}{l}\text { MAIA, Manoel Rodrigues. Diccionario das elypses, que } \\
\text { mais frequentemente se encontram nos auctores classi- } \\
\text { cos: interpretadas / Manoel Rodrigues Maia. Lisboa: Off. } \\
\text { de António Gomes, 1790, in-8. }\end{array}$ \\
\hline $\begin{array}{l}40 \\
F\end{array}$ & $\begin{array}{l}\text { Ditto das lingoas Inglezas } \\
\text { e Franceza avaliado por } \\
\text { mil duzentos e oitenta reis } \\
1 \$ 280\end{array}$ & $\begin{array}{l}\text { HARMONIÉRE, G. Nouveau dictionaire de poche fran- } \\
\text { çois-anglois et anglois-françois, contenant tous les mots } \\
\text { des deux langues, dont l'usage est autorisé. Paris: T. Bar- } \\
\text { rois, } 1816 \text {. }\end{array}$ \\
\hline $\begin{array}{l}41 \\
P\end{array}$ & $\begin{array}{l}\text { Elementos da Grammatica } \\
\text { Ingleza por Jonathas por } \\
\text { quatrocentos e oitenta reis } \\
\$ 480\end{array}$ & $\begin{array}{l}\text { ABBOTT, Jonathas. Elementos da grammatica ingleza. } \\
\text { Bahia: Imprensa Nacional, } 1827 .\end{array}$ \\
\hline
\end{tabular}


rev. hist. (São Paulo), n. 171, p. 245-286, jul.-dez., 2014 http://dx.doi.org/10.11606/issn.2316-9141.rh.2014.89013
Pablo Antonio Iglesias Magalhães

Deus e o diabo na biblioteca de um cônego da Bahia: 0 inventário dos livros do padre Manoel Dendê Bus em 1836

\begin{tabular}{|c|c|c|}
\hline $\begin{array}{l}42 \\
P\end{array}$ & $\begin{array}{l}\text { As duas lingoas, ou } \\
\text { grammatica Filosofica dois } \\
\text { volumes por mil e seiscen- } \\
\text { tos } r^{.} 1 \$ 600\end{array}$ & $\begin{array}{l}\text { BARBOSA, Jeronymo Soares. As duas linguas, ou } \\
\text { grammatica philosophica da lingua portugueza compara- } \\
\text { da com a latina, para ambas se aprenderem ao mesmo } \\
\text { tempo. Coimbra: Real Imp. da Universidade, } 1807 \text {, in- } 8 \text {. } \\
\text { O único exemplar que pude localizar é em um volume, e } \\
\text { não dois como no inventário. }\end{array}$ \\
\hline $\begin{array}{l}43 \\
P\end{array}$ & $\begin{array}{l}\text { Arte nova da lingoa Grega } \\
\text { avaliada por seiscentos e } \\
\text { quarenta reis } \$ 640\end{array}$ & $\begin{array}{l}\text { FARIA, fr. Custodio de. Arte nova da lingua grega, para uso } \\
\text { de Collegio da Graça de Coimbra, feita e oferecida à Vir- } \\
\text { gem Maria N. S. Coimbra: Real Typ. da Universidade, } 1790 .\end{array}$ \\
\hline $\begin{array}{l}44 \\
P\end{array}$ & $\begin{array}{l}\text { Mestre Francez, ou Novo } \\
\text { methodo para apprender } \\
\text { Francez avaliado em mil } \\
\text { reis } 1 \$ 000\end{array}$ & $\begin{array}{l}\text { DURAND, Francisco Clamopin. Mestre francez, ou novo } \\
\text { methodo per aprender a lingua franceza por meio da por- } \\
\text { tugueza, por Francisco Clamopin Durand, professor do } \\
\text { lingua franceza. Porto, } 1767 \text {, in-4. } \\
\text { Mestre francez, ou novo methodo para aprender a lingua } \\
\text { franceza por meio da portugueza... / F. C. D. 2a ed. cor- } \\
\text { rectissima. Lisboa: Off. Francisco Mendes Lima, } 1771 \text {. } \\
\text { Mestre francez, ou novo methodo para aprender com per- } \\
\text { feição, e ainda sem mestre, a lingua franceza por meio } \\
\text { da portugueza: confirmado com exemplos escolhidos, e } \\
\text { tirados dos melhores authores... / por Francisco Clamopin } \\
\text { Durand. Sexta edição emendada de muitos erros... Lisboa: } \\
\text { na Off. Simão Thaddeo Ferreira: vende-se na loja de Pedro } \\
\text { José Rei, mercador de livros ao Chiado na esquina da rua } \\
\text { nova de S. Francisco, } 1798 \text {. } \\
\text { Não pude ver a primeira edição, mas, entre } 1767 \text { e 1835, } \\
\text { houve } 10 \text { edições dessa gramática franco-portuguesa. }\end{array}$ \\
\hline $\begin{array}{l}45 \\
L\end{array}$ & $\begin{array}{l}\text { Francisci Sanctii Brocensis } \\
\text { Minerva avaliado por nove- } \\
\text { centos e sessenta reis } \$ 960\end{array}$ & $\begin{array}{l}\text { BROZAS, Francisco Sánchez de las. Franc. Sanctii Bro- } \\
\text { censis. Minerva, seu de causis linguae latinae commen- } \\
\text { tarius, cui inserta sunt, uncis inclusa quae addidit Gasp. } \\
\text { Scioppius; et subjectae suis paginis notae Jac. Perizonii. } \\
\text { Ulyssipone: Jussu Regis Fidelissimi Joseph I, 1760, } 11 \text {, } \\
\text { gravura calcográfica, } 862,32,29 \text { p., } 20 \mathrm{~cm} \text {. }\end{array}$ \\
\hline $\begin{array}{l}46 \\
L\end{array}$ & $\begin{array}{l}\text { Enchiridion seu Manuali } \\
\text { Hebraicum avaliado por } \\
\text { cento e sessenta reis } \$ 160\end{array}$ & $\begin{array}{l}\text { CUADROS, Diego Mart N. de. Enchiridion seu manuale } \\
\text { hebraicum ad usum regii seminarii matritensis: in duas } \\
\text { partes distributum. Roma: Typ. A. de Rubeis, } 1733 \text {, in-8. }\end{array}$ \\
\hline $\begin{array}{l}47 \\
F\end{array}$ & $\begin{array}{l}\text { Mestre Italiano, ou } \\
\text { Grammatica Franceza Ita- } \\
\text { liana [fl. } 40 \mathrm{v} \text { ] Italiana avalia- } \\
\text { do por seiscentos e quaren- } \\
\text { ta reis } \$ 640\end{array}$ & $\begin{array}{l}\text { VENERONI, J. Le maitre italien, ou la grammaire françoi- } \\
\text { se et italienne. Lyon, 1789, in-8. }\end{array}$ \\
\hline & $97 \$ 440$ & \\
\hline $\begin{array}{l}48 \\
P\end{array}$ & $\begin{array}{l}\text { Thesoiro da lingua Italiana } \\
\text { avaliado por novecentos e } \\
\text { sessenta reis } \$ 960\end{array}$ & $\begin{array}{l}\text { MICHELE, Antonio. Elementos da conversação italiana e } \\
\text { portugueza; Thesouro da lingua italiana ou seja methodo } \\
\text { para aprendella facilmente. Lisboa: Nova Offi. João Rodri- } \\
\text { gues Neves, } 1807,140,151 \text { p., } 18 \mathrm{~cm} \text {. }\end{array}$ \\
\hline
\end{tabular}


rev. hist. (São Paulo), n. 171, p. 245-286, jul.-dez., 2014 http://dx.doi.org/10.11606/issn.2316-9141.rh.2014.89013
Pablo Antonio Iglesias Magalhães

Deus e o diabo na biblioteca de um cônego da Bahia: 0 inventário dos livros do padre Manoel Dendê Bus em 1836

\begin{tabular}{|c|c|c|}
\hline $\begin{array}{l}49 \\
F / R\end{array}$ & $\begin{array}{l}\text { Huma grammattica France- } \\
\text { za por Hamoniere por nove- } \\
\text { centos e sessenta reis } \$ 960\end{array}$ & $\begin{array}{l}\text { HARMONIĖRE, G. Grammaire françoise a l'usage des } \\
\text { russes. Frantsuzskaia grammatika, soderzhashchaia v } \\
\text { sebe legkoi i osnovatel'noi sposob uchit'sia semu iazyku. } \\
\text { novoe izdanie, ispravlennoe i dopolnennoe g. Gamonie- } \\
\text { rom, sochinitelem frantsuzskago i rossiiskago slovaria. } \\
\text { Paris: chez Théophile Barrois fils, libraire pour les langues } \\
\text { étrangères vivantes, quai Voltaire, } n^{\circ} 11,1816 \text {. }\end{array}$ \\
\hline $\begin{array}{l}50 \\
F / E\end{array}$ & $\begin{array}{l}\text { Huma ditta Hespanhola por } \\
\text { oitocentos reis } \$ 800\end{array}$ & $\begin{array}{l}\text { HARMONIĖRE, G. Grammaire espagnole: divisée en } \\
\text { quatre parties, dont la première traite de la prononciation; } \\
\text { la seconde, des différentes espèces de mots; la troisiè- } \\
\text { me, de la syntaxe; et la quatrième, de l'orthographe, de } \\
\text { la ponctuation et de la prosodie: avec un appendice, con- } \\
\text { tenant des remarques diverses; suivie d'un cours de thè- } \\
\text { mes, et d'un traité de versification. Paris: T. Barrois, } 1821 .\end{array}$ \\
\hline $\begin{array}{l}51 \\
P\end{array}$ & $\begin{array}{l}\text { Nova Grammatica Ingleza } \\
\text { por Agostinho Neri avaliada } \\
\text { por seiscentos e quarenta } \\
\text { r.s } \$ 640\end{array}$ & $\begin{array}{l}\text { Nova grammatica da lingua ingleza: ou a arte de fallar, e } \\
\text { escrever com propriedade, e correcção o idioma Inglez, } \\
\text {... composta por Agostinho Neri da Silva. Terceira im- } \\
\text { pressão correcta. Lisboa: na Officina de Simão Thaddeo } \\
\text { Ferreira, anno 1800. Vende-se na loja de Paulo Martin, } \\
\text { 1800. 4a imp. Lisboa: Nova Offic. João Rodrigues Neves, } \\
\text { 1809. 4a imp. Lisboa: Imp. Regia, 1809. 5a imp. Lisboa: } \\
\text { Imp. Regia, 1812. 6a imp. Lisboa: Nova Offic. da V. Neves } \\
\text { Filhos, 1814. }\end{array}$ \\
\hline $\begin{array}{l}52 \\
P\end{array}$ & $\begin{array}{l}\text { Novo Methodo da Gramma- } \\
\text { tica Latina avaliado por } \\
\text { cento e sessenta reis } \$ 160\end{array}$ & $\begin{array}{l}\text { FIGUEIREDO, Antonio Pereira. Novo methodo da } \\
\text { grammatica latina, para uso das escholas da Congrega- } \\
\text { ção do Oratorio, ordenado e composto pela mesma con- } \\
\text { gregação / pe. António Pereira de Figueiredo. 1a ed. Lis- } \\
\text { boa: Offic. de Miguel Rodrigues, } 1752 \text {. }\end{array}$ \\
\hline $\begin{array}{l}53 \\
L\end{array}$ & $\begin{array}{l}\text { Graecae Linguae radices } \\
\text { por cento e sessenta reis } \\
\$ 160\end{array}$ & $\begin{array}{l}\text { Graecae linguae radices praecipuae: in suas orationis par- } \\
\text { tes ordine alphabetico digestae in usum scholarum. Olisi- } \\
\text { pone: Ex Typographia Regia, } 1772,276 \text { p., } 15 \mathrm{~cm} \text {. }\end{array}$ \\
\hline $\begin{array}{l}54 \\
L\end{array}$ & $\begin{array}{l}\text { Ausonii Popurae (sic) Frisii } \\
\text { de differentiis verborum por } \\
\text { trezentos e vinte reis } \$ 320\end{array}$ & $\begin{array}{l}\text { POPMA, Ausonius van. Ausonii Popmae, frisii, de diffe- } \\
\text { rentiis verborum. Libri IV, Et de usu antiquae locutionis. } \\
\text { Libri Duo, Nunc primum in Germania magno juventutis } \\
\text { bono editi, curante Bartholomaeo Musculo, Jc. Marpurgi } \\
\text { [Marburgo]: Typis \& Sumptibus Josephi Dieterici Hampelii, } \\
1646,[\mathrm{x}], 315 \text {, [xxv] p., in- } 12 \text {. } \\
\text { Obra que teve diversas edições em vários países euro- } \\
\text { peus. }\end{array}$ \\
\hline $\begin{array}{l}55 \\
L\end{array}$ & $\begin{array}{l}\text { Jo Georgii Walchii historia } \\
\text { critica avaliada por qui- } \\
\text { nhentos reis } \$ 500\end{array}$ & $\begin{array}{l}\text { WALCH, Johann Georg. Jo. Georgii Walchii Historia cri- } \\
\text { tica latinae linguae. Lipsiae: sumtu J. F. Gleditschii et filii, } \\
1716 . \\
\text { Teve reedições em } 1724 \text { em Colônia, em } 1729 \text { saiu ed. } \\
\text { nova, multis accessionibus auctior, além de edições em } \\
1734 \text { e } 1761 \text {. }\end{array}$ \\
\hline $\begin{array}{l}56 \\
L\end{array}$ & $\begin{array}{l}\text { Elementa Phisicae dois vo- } \\
\text { lumes avaliados avaliado } \\
\text { por trezen [fl. } 41 \text { ] trezentos } \\
\text { e sessenta reis } \$ 360\end{array}$ & $\begin{array}{l}\text { GENOVESI, Antonio. Elementa phisicae experimentalis. } \\
\text { Veneza: Bettinelli, } 1793,8^{\circ} \text {, cartoncino coevo, } 2 \text { vol., p. } \\
\text { VIII, } 182,192,3 \text { tavv. }\end{array}$ \\
\hline & $102 \$ 580$ & \\
\hline
\end{tabular}


rev. hist. (São Paulo), n. 171, p. 245-286, jul.-dez., 2014 http://dx.doi.org/10.11606/issn.2316-9141.rh.2014.89013
Pablo Antonio Iglesias Magalhães

Deus e o diabo na biblioteca de um cônego da Bahia: 0 inventário dos livros do padre Manoel Dendê Bus em 1836

\begin{tabular}{|c|c|c|}
\hline $\begin{array}{l}57 \\
L\end{array}$ & $\begin{array}{l}\text { Marci Tullii Ciceronis Ora- } \\
\text { tiones quatro volumes por } \\
\text { mil e seiscentos reis } 1 \$ 600\end{array}$ & $\begin{array}{l}\text { CICERO, Marco Túlio. M. T. Ciceronis orationum pars } i \\
\text { [-IV]. Cum argumentis, animadversionibus, \& analysi M. } \\
\text { Antonii Ferratii ad usum Seminarii Patavini. Patavii [Pá- } \\
\text { dua]: ex Typographia Seminarii apud Joannem Manfre } \\
\text { [1729], vol. } 1 \text { [18] 581, vol. } 2 \text { [2] 658, vol. } 3 \text { [2] 679, vol. } \\
4 \text { [2], } 709 \text { p. }\end{array}$ \\
\hline $\begin{array}{l}58 \\
\text { IT }\end{array}$ & $\begin{array}{l}\text { Trinta Novella avaliada por } \\
\text { cento e sessenta reis } \$ 160\end{array}$ & $\begin{array}{l}\text { BOCCACCIO, Giovanni. Trenta novelle di Messer Giovan- } \\
\text { ni Boccaccio scelte dal suo Decamerone - Ad uso de' mo- } \\
\text { desti giovani e studiosi della Toscana favella - con la descri- } \\
\text { zione della pestilenza stata in Firenze nel } 1348 \text { dellastesso } \\
\text { autore. II tutto tratto con somma diligenza dagli ottimi } \\
\text { Testi. Veneza: Francesco Andreola, 1817, in- } 8^{\circ}, 240 \text { p. } \\
\text { Houve cerca de trinta edições dessa obra até o primeiro } \\
\text { quartel do século XIX. }\end{array}$ \\
\hline $\begin{array}{l}59 \\
P\end{array}$ & $\begin{array}{l}\text { As noites Clementinas por } \\
\text { duzentos e quarenta r.s } \\
\$ 240\end{array}$ & $\begin{array}{l}\text { BERTOLA, Jorge. As noites clementinas: poema em qua- } \\
\text { tro cantos sobre a morte de Clemente XIV, Ganganelli / } \\
\text { por d. Jorge Bertola; tradução livre do italiano por Carra- } \\
\text { cioli; traduzido do francez para o portuguez por fr. João } \\
\text { de Nossa Senhora da Graça. Lisboa: na Regia Officina } \\
\text { Typografica, } 1785,2 \text { vol., } 17 \mathrm{~cm} \text {; nova ed.. Lisboa: Typ. } \\
\text { Rollandiana, } 1816 \text {. }\end{array}$ \\
\hline $\begin{array}{l}60 \\
P\end{array}$ & $\begin{array}{l}\text { O Hyssope Poema por } \\
\text { quatrocentos e oitenta reis } \\
\$ 480\end{array}$ & $\begin{array}{l}\text { CRUZ E SILVA, Antonio Diniz. O Hyssope: poema heroi- } \\
\text { comico. Londres [Paris: s.n.], 1802, iv, } 115 \text { [1] p., } 18 \mathrm{~cm} \text {. } \\
\text { O Hyssope: poema heroi-comico. Lisboa: Typ. Rollandia- } \\
\text { na, 1808, in-8, } 128 \text { p. } \\
\text { O Hyssope: poéma heroi-comico. Nova ed. correcta, com } \\
\text { variantes, prefácio e notas. Paris: Officina de A. Bobée, } \\
1817 \text { [4], XXXIII [3], } 137 \text { [2] p., [1] grav., il., } 19 \mathrm{~cm} \text {. } \\
\text { O Hyssope: poema herói-cómico. Nova ed. revista correc- } \\
\text { ta e ampliada de notas. Paris: Officina de P. N. Rougeron, } \\
1821, \text { XXXVIII, } 198 \text { p., } 18 \mathrm{~cm} \text {. }\end{array}$ \\
\hline $\begin{array}{l}61 \\
P\end{array}$ & $\begin{array}{l}\text { Traducção de Sallustio com } \\
\text { o texto latino avaliado por } \\
\text { trezentos e vinte reis } \$ 320\end{array}$ & $\begin{array}{l}\text { Sallustio em português / trad. J. V. Barreto Feio. Paris: } \\
\text { Livraria Nacional e Estrangeira, 1825, } 397 \text { [3] p., } 15 \mathrm{~cm} \text {. }\end{array}$ \\
\hline $\begin{array}{l}62 \\
P\end{array}$ & $\begin{array}{l}\text { Jornada de Africa por Hie- } \\
\text { ronimo avaliado por duzen- } \\
\text { tos e quarenta reis } \$ 240\end{array}$ & $\begin{array}{l}\text { MENDONÇA, Jerônimo Furtado de. Iornada de Africa / } \\
\text { composta por Hieronimo de Mendonça Furtado... por Ben- } \\
\text { to Joze de Souza Farinha. Lisboa: na Offic. de Joze da } \\
\text { Silva Nazareth, } 1785 \text { [18], } 275 \text { p., } 18 \mathrm{~cm} \text {. } \\
\text { A primeira edição de } 1607 \text { bem como as edições espa- } \\
\text { nholas de } 1622 \text { e } 1630 \text { deste poema épico já eram raras } \\
\text { no começo do século XIX. }\end{array}$ \\
\hline $\begin{array}{l}63 \\
L\end{array}$ & $\begin{array}{l}\text { Marci Tullii Ciceronis por } \\
\text { duzentos e quarenta r.s } \\
\$ 240\end{array}$ & $\begin{array}{l}\text { CíCERO, Marco Túlio. M. Tullii Ciceronis. Orationes se- } \\
\text { lectae ad usum Scholarum Lusitanarum Jussu Josephi } \\
\text { I. Regis fidelissimi. editae et sacundum Josephi Oliveti. } \\
\text { Editionem emendatae. Olisípone: ex Typographia Regia, } \\
1793 \text { [5 fl.], } 424 \text { p., } 16 \mathrm{~cm} \text {. }\end{array}$ \\
\hline
\end{tabular}


rev. hist. (São Paulo), n. 171, p. 245-286, jul.-dez., 2014 http://dx.doi.org/10.11606/issn.2316-9141.rh.2014.89013
Pablo Antonio Iglesias Magalhães

Deus e o diabo na biblioteca de um cônego da Bahia: 0 inventário dos livros do padre Manoel Dendê Bus em 1836

\begin{tabular}{|c|c|c|}
\hline $\begin{array}{l}64 \\
P\end{array}$ & $\begin{array}{l}\text { Fabulas escolhidas entre } \\
\text { as de la Fontaine por du- } \\
\text { zentos e quarenta reis } \$ 240\end{array}$ & $\begin{array}{l}\text { Fábulas escolhidas entre as de J. la Fontaine: traduzidas } \\
\text { em portuguez / por Francisco Manoel do Nascimento. } \\
\text { Londres: na Typographia de H. Bryer. 1813, } 2 \text { vol., } 16 \mathrm{~cm} \text {. } \\
\text { Fabulas escolhidas entre as de J. La Fontaine; trad. Fran- } \\
\text { cisco Manoel do Nascimento. Lisboa: Imp. Regia, 1814, } 1 \\
\text { vol. em } 2 \mathrm{t} \text {., } 8^{\circ} \text {. } \\
\text { Fábulas escolhidas entre as de J. la Fontaine: traduzidas } \\
\text { em verso portuguez, e emendadas sobre a edição feita } \\
\text { em Londres... / por Francisco Manoel do Nascimento. Pa- } \\
\text { ris: na Officina de Cellot, } 1815,2 \text { vol., } 16 \mathrm{~cm} \text {. }\end{array}$ \\
\hline $\begin{array}{l}65 \\
F\end{array}$ & $\begin{array}{l}\text { De la santé des gens de } \\
\text { lettres por Monsieur Tissot } \\
\text { por duzentos e quarenta } \\
\text { reis } \$ 240\end{array}$ & $\begin{array}{l}\text { TISSOT, Samuel Auguste André David. De la santé des } \\
\text { gens de lettres, par M. Tissot, D. \& P. en Médecine. A Lau- } \\
\text { sanne: chez François Grasset \& Compagnie, } 1768 . \\
\text { Teve reedições em } 1769 \text { e } 1775 \text {. }\end{array}$ \\
\hline $\begin{array}{l}66 \\
\text { L }\end{array}$ & $\begin{array}{l}\text { Publii Virgilii Maronis Opera } \\
\text { Parisier avaliado por dois } \\
\text { mil } 2 \$ 000\end{array}$ & $\begin{array}{l}\text { Publii Virgilii Maronis Opera Paris. Paris: Barbou, } 1767 \text {, } \\
3 \text { vol., in-8. } \\
\text { Há outra edição em um volume: Publii Virgilii Maronis } \\
\text { quae extant omnia opera. Paris: Lemaire, 1819, in-8. }\end{array}$ \\
\hline & $109 \$ 580$ & \\
\hline $\begin{array}{l}67 \\
P\end{array}$ & $\begin{array}{l}\text { [fl. } 41 \mathrm{v} \text { ] Elementos de Ari- } \\
\text { thimetica por Monsieur Be- } \\
\text { sout avaliado por seiscen- } \\
\text { tos e quarenta reis } \$ 640\end{array}$ & $\begin{array}{l}\text { BEZOUT, Etienne. Elementos de arithmetica / par M. } \\
\text { Bezout; traduzido do francez por Custódio Gomes Villas } \\
\text { Boas. Coimbra: na Real Officina da Universidade, } 1791 \text {, } \\
\text { VI, } 270 \text { p., } 4^{\circ}, 18 \mathrm{~cm} \text {. } \\
9 \text { a ed, Coimbra: Real Imprensa da Universidade, } 1816 \text {, } \\
\text { VIII, } 264 \text { p., } 16 \mathrm{~cm} \text {. }\end{array}$ \\
\hline $\begin{array}{l}68 \\
P\end{array}$ & $\begin{array}{l}\text { Recreação Filosofica do } \\
\text { Padre Theodoro de Almei- } \\
\text { da por dois mil e quatrocen- } \\
\text { tos } r^{\text {s }} 2 \$ 400\end{array}$ & $\begin{array}{l}\text { D'ALMEIDA, Teodoro. Recreasão filozofica, ou dialogo } \\
\text { sobre a filozofia natural, para instrucção de pesoas curio- } \\
\text { zas, que não frequentárão as aulas / pelo P. Teodoro d'Al- } \\
\text { meida. 3a imp. muito mais aumentada e correcta que as } \\
\text { precedentes. Lisboa: na Off. de Miguel Rodrigues, } 1758- \\
1785,7 \text { vol., il., } 17 \mathrm{~cm} \text {. A primeira edição traz o nome de } \\
\text { Theodosio Eugenio Silvio. Lisboa: na Officina de Miguel } \\
\text { Rodrigues, } 1751,10 \text { vol. }\end{array}$ \\
\hline $\begin{array}{l}69 \\
P\end{array}$ & $\begin{array}{l}\text { Cartas interessantes do } \\
\text { Papa Clemente avaliadas } \\
\text { por oitocentos reis } \$ 800\end{array}$ & $\begin{array}{l}\text { Cartas interessantes do papa Clemente XIV (Ganganelli) } \\
\text { traduzidas da língua franceza, e oferecidas á ill. }{ }^{\text {ma }} \text { e ex } \\
\text { sª }^{\circ} \text { d. Marianna Xavier de Assis Mascarenhas, marquesa } \\
\text { de Castello-melhor. Lisboa: na Offic. Patr. de Francisco } \\
\text { Luis Ameno, } 1785,8^{\circ} \text { de xxiv-344 p. e mais duas de índi- } \\
\text { ce. Tomo II, ibi, na Offic. de Simão Thaddeo Ferreira, } 1784 \\
\text { (sic), } 8^{\circ} \text { de } 312 \text { p. Tomo III, ibi, na Offic. da Academia Real } \\
\text { das Sciencias, } 1784,8^{\circ} \text { de } 308 \text { p. Tomo IV (Appendice ás } \\
\text { cartas interessantes etc.), ibi, na Offic. de Francisco Luis } \\
\text { Ameno, } 1786,8^{\circ} \text { de } 245 \text { p. e duas de índice. } \\
\text { Lisboa: Borel, } 1785,3 \text { v., } 17 \mathrm{~cm} \text {. } \\
\text { 3a imp. Porto: na Off. de Pedro Ribeiro França, e Viuva } \\
\text { Emary, } 1791,2 \text { vol., } 15 \mathrm{~cm} \text {. }\end{array}$ \\
\hline
\end{tabular}


rev. hist. (São Paulo), n. 171, p. 245-286, jul.-dez., 2014 http://dx.doi.org/10.11606/issn.2316-9141.rh.2014.89013
Pablo Antonio Iglesias Magalhães

Deus e o diabo na biblioteca de um cônego da Bahia: 0 inventário dos livros do padre Manoel Dendê Bus em 1836

\begin{tabular}{|c|c|c|}
\hline $\begin{array}{l}70 \\
P\end{array}$ & $\begin{array}{l}\text { Obras do Doutor Sá e Mi- } \\
\text { randa avaliados por duzen- } \\
\text { tos e quarenta reis } \$ 240\end{array}$ & $\begin{array}{l}\text { SÀ DE MIRANDA, Francisco de. As obras do celebrado } \\
\text { lusitano o doutor Francisco de Sá de Miranda. Lisboa: Im- } \\
\text { pressão Regia, } 1804,500,[6] \text { p., } 15 \mathrm{~cm} \text {. } \\
\text { As obras de Sá de Miranda foram impressas pela primei- } \\
\text { ra vez em } 1595 \text { e muitas vezes reimpressas no século } \\
\text { XVII. A Tipografia Rollandiana publicou-as em } 1784 \text {, com } \\
\text { dois volumes. A descrição do inventário indica tratar-se de } \\
\text { volume único, que é a de Lisboa em } 1804 \text {. Além disso, o } \\
\text { preço indica uma edição vulgar, como é a da Impressão } \\
\text { Régia, acima descrita. }\end{array}$ \\
\hline $\begin{array}{l}71 \\
P\end{array}$ & $\begin{array}{l}\text { Colleção das Instrucçoens } \\
\text { de Pedro Freire por duzen- } \\
\text { tos e quarenta reis } \$ 240\end{array}$ & $\begin{array}{l}\text { D'OLIVEIRA, Pedro Freire. Collecção das instruções, que } \\
\text { dá aos seus discipulos no exercicio da latinidade: com um } \\
\text { tratado sobre os costumes dos romanos, ceremonias tan- } \\
\text { to civis como militares etc. / Pedro Freire de Oliveira. Nova } \\
\text { ed. Lisboa: Imp. Regia, 1819, in-8. } \\
\text { Parece-me tratar-se dessa segunda edição. A primeira } \\
\text { edição só traz um "l" no título: Colecção das instrucções } \\
\text { que dá aos seus discípulos no exercício da latinidade / } \\
\text { Pedro Freire d'Oliveira. Lisboa: Offic. de Francisco Luiz } \\
\text { Ameno, } 1790,1 \text { vol., } 20 \mathrm{~cm} \text {. }\end{array}$ \\
\hline $\begin{array}{l}72 \\
P\end{array}$ & $\begin{array}{l}\text { Antonii Pereriae Collectio } \\
\text { avaliada por duzentos e } \\
\text { quarenta reis } \$ 240\end{array}$ & $\begin{array}{l}\text { PEREIRA, Antonio. Collecçam de palavras familiares as- } \\
\text { sim portuguezas como latinas, que para o uso das escolas } \\
\text { da Congregaçaõ do Oratorio / coordinou e illustrou com } \\
\text { notas Antonio Pereira padre da mesma Congregaçaõ }= \\
\text { Collectio verborum familiarium cùm Lusitanorum tum la- } \\
\text { tinorum, quae in usum scholarum Congragationis Oratorii } \\
\text { digessit ac notis illustravit Antonius Pereira ejusdem Con- } \\
\text { gregationis. Segunda impressaõ mais correcta e aumen- } \\
\text { tada. Lisboa: na Officina de Miguel Rodrigues, impressor } \\
\text { do eminent. senhor card. patr., 1757, [24], 165, [3] p., } 8^{\circ} \text {, } \\
15 \mathrm{~cm} \text {. Essa é a segunda edição. A primeira é de Lisboa: } \\
\text { Miguel Rodrigues, } 1755, \text { A } 3^{a} \text { é de Lisboa: Miguel Menes- } \\
\text { cal da Costa, } 1759 \text {. Foi reimpresso até o século XIX. }\end{array}$ \\
\hline $\begin{array}{l}73 \\
F\end{array}$ & $\begin{array}{l}\text { Republica Romana seis vo- } \\
\text { lumes todos por novecen- } \\
\text { tos e sessenta reis } \$ 960\end{array}$ & $\begin{array}{l}\text { BEAUFORT, Louis de. La République romaine ou plan } \\
\text { général de l'ancien gouvernement de Rome, où l'on dé- } \\
\text { veloppe les différens ressorts de ce gouvernement, l'in- } \\
\text { fluence qu'y avoit la religion; la souveraineté du peuple, \& } \\
\text { la manière dont il l'exerçoit: quelle étoit l'autorité du Sénat } \\
\text { \& celle des magistrats, l'administration de la justice, les } \\
\text { prérogatives du citoyen romain \& les différentes conditions } \\
\text { des sujets de ce vaste empire. Paris: } 1767,6 \text { vol., in-12. } \\
\text { A primeira edição é de A La Haye: chez Nicolas van Daalen, } \\
\text { 1766, 12-XXXVII-430 + 434-[6]. }\end{array}$ \\
\hline $\begin{array}{l}74 \\
L\end{array}$ & $\begin{array}{l}\text { Prozodia Boroniensis por } \\
\text { cento e sessenta reis } \$ 160\end{array}$ & $\begin{array}{l}\text { RICCIOLIO, Jo. Baptista. Prosodia bonomiensis reforma- } \\
\text { ta: et ex duobus tomus in unum ab ipso auctore redacta } \\
\text { nec sola rudimenta prosodiae pro Tyronibus, sed proso- } \\
\text { diam majorem... / auctore P. Jo. Baptista Ricciolio. Patavii: } \\
\text { Typis Seminarii, 1746, [12], } 695 \text { p., } 16 \mathrm{~cm} \text {. }\end{array}$ \\
\hline
\end{tabular}


rev. hist. (São Paulo), n. 171, p. 245-286, jul.-dez., 2014 http://dx.doi.org/10.11606/issn.2316-9141.rh.2014.89013
Pablo Antonio Iglesias Magalhães

Deus e 0 diabo na biblioteca de um cônego da Bahia: 0 inventário dos livros do padre Manoel Dendê Bus em 1836

\begin{tabular}{|c|c|c|}
\hline $\begin{array}{l}75 \\
P\end{array}$ & $\begin{array}{l}\text { Os Deveres do homem, ou } \\
\text { cathecismo moral por du- } \\
\text { zentos e quarenta reis } \$ 240\end{array}$ & $\begin{array}{l}\text { [VANESIO, Eusébio]. Direitos, e deveres do homem, ou ca- } \\
\text { thecismo moral, e filozofico para instrucção da mocidade. } \\
\text { Berlim: [s.n.], 1815, [2], } 16 \text { p., [28] fol. em branco, } 15 \mathrm{~cm} \text {. } \\
2^{\mathrm{a}} \text { ed. Deveres do homem ou cathecismo moral / Ezebio } \\
\text { Vanezio. Lisboa: na Impressão Regia, } 1819,1 \text { vol., } 8^{\circ} \text {. }\end{array}$ \\
\hline $\begin{array}{l}76 \\
P\end{array}$ & $\begin{array}{l}\text { O Thesoiro de Me [fl.42] de } \\
\text { Meninos avaliado por tre- } \\
\text { zentos e vinte reis } \$ 320\end{array}$ & $\begin{array}{l}\text { BLANCHARD, Pierre. Thesouro de meninos: resumo de } \\
\text { historia natural, para uso da mocidade de ambos os se- } \\
\text { xos e instrucção das pessoas, que desejão ter noções da } \\
\text { historia dos tres reinos da natureza / Pedro Blanchard; } \\
\text { traduzida do francez, e offrerecida á mocidade portugue- } \\
\text { za por Matheus José da Costa. Lisboa: Impressão Regia, } \\
\text { 1807-1819, } 5 \text { vol., in-8 } \\
\text { 2.ed. Lisboa: Impressão Regia, } 1814-1824,6 \text { vol., in- } 8^{\circ} \text {. }\end{array}$ \\
\hline & $115 \$ 500$ & \\
\hline $\begin{array}{l}77 \\
P\end{array}$ & $\begin{array}{l}\text { Macarronea Latina avalia- } \\
\text { da por trezentos e vinte reis } \\
\$ 320\end{array}$ & $\begin{array}{l}\text { Macarronea latino-portugueza: quer dizer amontoado de } \\
\text { versos macarronicos latino-portuguezes, que alguns poe- } \\
\text { tas de bom humor destilaraõ do alambique da cachimonia } \\
\text { para desterro da melancolia. Lisboa: na Officina Patriarcal } \\
\text { de Francisco Luiz Ameno, } 1765,176[4] \text { p., } 8^{\circ}, 16 \mathrm{~cm} \text {. } \\
2^{\mathrm{a}} \text { ed Lisboa: Imp. Regia, 1816, IV, } 329 \text { p., } 8^{\circ} \text {. }\end{array}$ \\
\hline $\begin{array}{l}78 \\
P\end{array}$ & $\begin{array}{l}\text { A vida de Dom João de } \\
\text { Castro por trezentos e vinte } \\
\text { reis } \$ 320\end{array}$ & $\begin{array}{l}\text { ANDRADE, Jacinto Freire de. Vida de dom João de Cas- } \\
\text { tro quarto viso-rey da India / escrita por Jacinto Freyre de } \\
\text { Andrada; impressa por ordem de seu neto o bispo dom } \\
\text { Francisco de Castro. Lisboa: na Officina Craesbeeckiana, } \\
\text { 1651, [8], 444, [48] p., [2] f. grav., il., } 28 \mathrm{~cm} \text {. } \\
\text { Teve muitas reedições: } \\
\text { Lisboa: na Officina de loam da Costa, a custa de Anto- } \\
\text { nio Leite mercador de liuros na Rua Nova, 1671; Lisboa } \\
\text { Occidental: na Off. da Musica, } 1722 ; \text { Lisboa Occidental: } \\
\text { na Off. de Antonio Isidoro da Fonseca, 1736; Lisboa: na } \\
\text { Officina de Domingos Rodrigues, } 1747 \text {; Nova ed. emen- } \\
\text { dada e acrescentada da vida do autor. Lisboa: na Offic. de } \\
\text { Antonio Gomes, } 1786 . ; \text { Lisboa: na Off. de Simão Thaddeo } \\
\text { Ferreira: vende-se na loja de Pedro José Rey, mercador } \\
\text { de livros ao Xiado na esquina da Rua Nova de S. Francis- } \\
\text { co, 1798; Madri: Offic. Regia, } 1802 . \\
\text { Vida de d. João de Castro, quarto viso-rei da India / es- } \\
\text { crita por Jacinto Freire de Andrada. Nova ed. emendada } \\
\text { e acrescent. Rio de Janeiro: P. C. Dalbin [Distrib.], } 1818 \text {. }\end{array}$ \\
\hline $\begin{array}{l}79 \\
P\end{array}$ & $\begin{array}{l}\text { O gozo de si mesmo por } \\
\text { duzentos e quarenta reis } \\
\$ 240\end{array}$ & $\begin{array}{l}\text { O gozo de si mesmo / Caracciolo. Lisboa: Typ. Rollandia- } \\
\text { na, } 1789,6,399 \text { p., } 16 \mathrm{~cm} \text {. }\end{array}$ \\
\hline
\end{tabular}


rev. hist. (São Paulo), n. 171, p. 245-286, jul.-dez., 2014 http://dx.doi.org/10.11606/issn.2316-9141.rh.2014.89013
Pablo Antonio Iglesias Magalhães

Deus e o diabo na biblioteca de um cônego da Bahia: 0 inventário dos livros do padre Manoel Dendê Bus em 1836

\begin{tabular}{|c|c|c|}
\hline $\begin{array}{l}80 \\
P\end{array}$ & $\begin{array}{l}\text { Historia de Gil Braz por mil } \\
\text { e seiscentos } r^{\mathrm{s}} 1 \$ 600\end{array}$ & $\begin{array}{l}\text { LE SAGE, Alain. História de Gil Braz de Santilhana / tradu- } \\
\text { zida em portuguez por Manuel Maria Barbosa du Bocage. } \\
\text { Lisboa: Off. de Simão Thaddeo Ferreira [Régia Off. Typo- } \\
\text { gráfica], } 1797 . \\
\text { Historia de Gil Braz de Santilhana: traduzida em portu- } \\
\text { guez. } 2^{a} \text { ed. Lisboa: Typografia da Academia Real das } \\
\text { Sciências, } 1800 . \\
\text { Historia de GilBrazde Santilhana/Alain RenéLesage. Nova } \\
\text { ed. rev. e emendada. Paris: Theophilo Barrois Filho, } 1819 . \\
\text { História de Gil Braz de Santilhana / Le Sage. Lisboa: Typ. } \\
\text { da Acad. R. das Sciencias, } 1821 .\end{array}$ \\
\hline $\begin{array}{l}81 \\
P\end{array}$ & $\begin{array}{l}\text { Tratado sobre as partidas } \\
\text { dobradas avaliado por } \$ 240\end{array}$ & 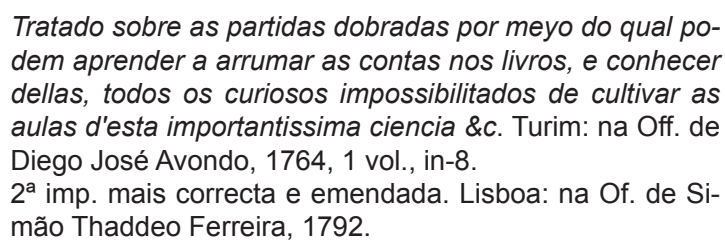 \\
\hline $\begin{array}{l}82 \\
P\end{array}$ & $\begin{array}{l}\text { Geografia Moderna por } \\
\text { Rego avaliada por trezen- } \\
\text { tos e quarenta reis } \$ 340\end{array}$ & $\begin{array}{l}\text { REGO, José Antonio da Silva. Geografia moderna de } \\
\text { Portugal e Hespanha, precedida de hum pequeno tratado } \\
\text { da esfera e globo terrestre... / por Joze Antonio da Silva } \\
\text { Rego. Lisboa: Off. de J. F. M. de Campos, 1816, [8], } 324 \\
\text { p., } 16 \mathrm{~cm} \text {. }\end{array}$ \\
\hline $\begin{array}{l}83 \\
L\end{array}$ & $\begin{array}{l}\text { Marci Tullii Ciceronis Epis- } \\
\text { tola avaliada por trezentos } \\
\text { reis } \$ 300\end{array}$ & $\begin{array}{l}\text { CICERO, Marco Túlio. Epistolarum ad quintum fratrem } \\
\text { libri tres, et ad brutum... / M. Tullii Ciceronis, cum notis } \\
\text { integris Petri Victorii. Hagae Comitum: Isaacum Vaillant, } \\
1725, \text { XIV, } 580 \text { p., } 8,20 \mathrm{~cm} \text {. }\end{array}$ \\
\hline $\begin{array}{l}84 \\
P\end{array}$ & $\begin{array}{l}\text { Vida de Luis deseseis (sic) } \\
\text { por duzentos e quarenta } \\
\text { reis } \$ 240\end{array}$ & $\begin{array}{l}\text { LIMON. Vida de Luiz XVI rei de França / por mr. Limon. } \\
\text { Lisboa: Of. de João Procopio Correa da Silva, } 1801 .\end{array}$ \\
\hline $\begin{array}{l}85 \\
P\end{array}$ & $\begin{array}{l}\text { Noites de Young traduzidas } \\
\text { em vulgar avaliadas por tre- } \\
\text { zentos e vinte reis } \$ 320\end{array}$ & $\begin{array}{l}\text { YOUNG, Edward. Tradução de Vicente Carlos de Oliveira. } \\
\text { Noites de Young / traducção de Vicente Carlos de Oliveira } \\
\text { addicionada com muitas notas importantes e com o Triunfo } \\
\text { da Religião e outros opusculos do mesmo Young. Lisboa: } \\
\text { na Typografia Rollandiana, } 1781, \mathrm{XV}, 269 \text {, [1] p., } 15 \mathrm{~cm} \text {. } \\
\text { Teve reimpressões em } 1783 \text { e 1785. As seguintes, } 1791 \text { e } \\
\text { 1804, saíram em dois volumes. }\end{array}$ \\
\hline $\begin{array}{l}86 \\
P\end{array}$ & $\begin{array}{l}\text { Nunno Pompilio segundo } \\
\text { Rei de Roma, avalia [fl. 42] } \\
\text { avaliado por trezentos e } \\
\text { vinte reis } \$ 320\end{array}$ & $\begin{array}{l}\text { FLORIAN, Jean Pierre Claris de. Numa Pompílio, segun- } \\
\text { do rei de Roma / Por mr. de Florian. Lisboa: Typografia } \\
\text { Rollandiana, } 1805,2 \text { vol., } 15 \mathrm{~cm} \text {. }\end{array}$ \\
\hline & $119 \$ 640$ & \\
\hline
\end{tabular}


rev. hist. (São Paulo), n. 171, p. 245-286, jul.-dez., 2014 http://dx.doi.org/10.11606/issn.2316-9141.rh.2014.89013
Pablo Antonio Iglesias Magalhães

Deus e o diabo na biblioteca de um cônego da Bahia: 0 inventário dos livros do padre Manoel Dendê Bus em 1836

\begin{tabular}{|c|c|c|}
\hline $\begin{array}{l}87 \\
P\end{array}$ & $\begin{array}{l}\text { Os tres livros de Cícero so- } \\
\text { bre as obrigaçoens civis por } \\
\text { trezentos e vinte reis } \$ 320\end{array}$ & $\begin{array}{l}\text { CICERO, Marco Túlio. Os tres livros de Cicero sobre as } \\
\text { obrigações civis / traduzidos em lingua portugueza para } \\
\text { uso do Real Collegio de Nobres. Lisboa: na Offic. de } \\
\text { Miguel Manescal da Costa, Impressor do Santo Officio, } \\
\text { 1766, [24], } 155,94,124 \text { p., } 16^{\circ}, 11 \mathrm{~cm} \text {. } \\
\text { Os tres livros de Cicero sobre as obrigações civis tradu- } \\
\text { zidos em lingua portugueza. Nova ed. Lisboa: na Typ. } \\
\text { Rollandiana, 1825, [2], 209, [11] p., } 15 \mathrm{~cm} \text {. }\end{array}$ \\
\hline $\begin{array}{l}88 \\
P\end{array}$ & $\begin{array}{l}\text { Ensaios de eloquencia so- } \\
\text { bre diversos assumptos por } \\
\text { trezentos e vinte reis } \$ 320\end{array}$ & $\begin{array}{l}\text { Ensaios de eloquência sobre diversos assuntos interes- } \\
\text { santes. Lisboa: Regia Offi. Typ., 1791, } 1 \text { vol., in-8. }\end{array}$ \\
\hline $\begin{array}{l}89 \\
P\end{array}$ & $\begin{array}{l}\text { Rimas de Bocage por tre- } \\
\text { zentos e vinte reis } \$ 320\end{array}$ & $\begin{array}{l}\text { BOCAGE, Manuel Maria Barbosa du. Rimas. Lisboa: Off. } \\
\text { Simão Thaddeo Ferreira, } 1791 . \\
\text { 2a ed: Lisboa: Off. Simão Thaddeo Ferreira, 1800, } 351 \\
\text { p., } 20 \mathrm{~cm} \text {. } \\
\text { 3a ed: Lisboa: na Of. de Simão Thaddeo Ferreira, } 1806 .\end{array}$ \\
\hline $\begin{array}{l}90 \\
P\end{array}$ & $\begin{array}{l}\text { Segredo das Artes libera- } \\
\text { es avaliado por duzentos e } \\
\text { quarenta reis } \$ 240\end{array}$ & $\begin{array}{l}\text { FEIO SERPA, Joaquim. Segredos das artes liberaes, e } \\
\text { mecanicas, recopilados e traduzidos de vários authores } \\
\text { selectos, que trataõ de física, pintura, architectura, opti- } \\
\text { ca, quimica, douradora, e acharoado, com outras varias } \\
\text { curiosidades proveitosas, e divertidas. Seu autor o licen- } \\
\text { ciado d. Bernardo de Monton. Vertido de castelhano em } \\
\text { portuguez. Por Joaquim Feyo Cerpa. Lisboa: na Offic. de } \\
\text { Domingos Gonsalves, M. Dcc.xliv, [1744], in } 8^{\circ} \text {, de } 14 \times 10 \\
\mathrm{~cm} \text {, com [xxiv], } 176 \text { p. Teve segunda edição. Lisboa: Typ. } \\
\text { Rollandiana, } 1818,1 \text { vol. em } 2 \text { t., il., } 15 \mathrm{~cm} \text {. }\end{array}$ \\
\hline $\begin{array}{l}91 \\
P\end{array}$ & $\begin{array}{l}\text { Compendio das epocas, e } \\
\text { sucessos mais illustres da } \\
\text { historia geral por trezentos } \\
\text { e vinte } r^{s} \$ 320\end{array}$ & $\begin{array}{l}\text { FIGUEIREDO, Antonio Pereira de. Compêndio das epo- } \\
\text { cas e successos mais illustres da história geral. Lisboa: } \\
\text { Regia Offic. Typ., } 1782, \mathrm{VI}, 410 \mathrm{p} ., 16 \mathrm{~cm} \text {. } \\
2^{\mathrm{a}} \text { ed. Lisboa: na Typografia da Academia Real das Scien- } \\
\text { cias, vende-se na loja da Viuva Bertrand e Filho, merca- } \\
\text { dores de livros junto à Igreja dos Martyres ao Chiado em } \\
\text { Lisboa, } 1800, \text { VI, } 420 \text { p., } 8^{\circ}, 15 \mathrm{~cm} \text {. } \\
\text { 3a impr. Lisboa: Typ. Rollandiana, } 1825 \text {, VIII, } 376 \text { p., } 15 \mathrm{~cm} \text {. }\end{array}$ \\
\hline $\begin{array}{c}92 \\
P\end{array}$ & $\begin{array}{l}\text { Historia geral avaliada em } \\
\text { trezentos e vinte } r^{\text {s }} \$ 320\end{array}$ & $\begin{array}{l}\text { A indicação de Franco Lima esta demasiado imprecisa. } \\
\text { Poderia ser um volume isolado das duas gigantescas } \\
\text { obras intituladas História geral de Portugal por mr. de La } \\
\text { Clede. Lisboa: na Typografia Rollandiana, 1781, com } 16 \\
\text { volumes; ou Historia geral de Portugal e suas conquistas } \\
\text { por Damião Antonio de Lemos Faria e Castro. Lisboa: na } \\
\text { Typ. Rollandiana, 1786, com } 20 \text { volumes. } \\
\text { Franco Lima, contudo, não observou que o livro estava } \\
\text { truncado. Assim, a única obra que pude encontrar com o } \\
\text { título de "História geral" em língua portuguesa, anterior a } \\
1836 \text {, em volume único, é o que abaixo indico: } \\
\text { Historia geral da franc-maçonaria desde o seu estabeleci- } \\
\text { mento atéaos nossos dias.../porJ. F. Verhnes. Rio de Janei- } \\
\text { ro: Typ. Imp. de Seignot-Plancher, 1832, [4], } 139 \text { p., } 15 \mathrm{~cm} \text {. }\end{array}$ \\
\hline
\end{tabular}


rev. hist. (São Paulo), n. 171, p. 245-286, jul.-dez., 2014 http://dx.doi.org/10.11606/issn.2316-9141.rh.2014.89013
Pablo Antonio Iglesias Magalhães

Deus e o diabo na biblioteca de um cônego da Bahia: 0 inventário dos livros do padre Manoel Dendê Bus em 1836

\begin{tabular}{|c|c|c|}
\hline $\begin{array}{l}93 \\
F\end{array}$ & $\begin{array}{l}\text { Emilia, (sic) ou de l'educa- } \\
\text { tion por João Jacques Rou- } \\
\text { sseau por trezentos e vinte } \\
\text { r.s } \$ 320\end{array}$ & $\begin{array}{l}\text { ROUSSEAU, Jean-Jacques. Emile, ou De l'éducation. } \\
\text { The Hague: Jean Neaulme [i.e. Paris: Nicolas-Bonaven- } \\
\text { ture Duchesne], } 1762,4 \text { vol. } \\
\text { Não pude encontrar nenhum exemplar de Emile em volu- } \\
\text { me único antes de } 1836 \text {. Possivelmente, trata-se de obra } \\
\text { truncada ou com dois volumes encadernados em um. Não } \\
\text { foi possível identificar o exemplar e, por essa razão, limi- } \\
\text { tei-me a registrar a primeira edição acima. }\end{array}$ \\
\hline $\begin{array}{l}94 \\
P\end{array}$ & $\begin{array}{l}\text { Os Martires, ou o Triunfo da } \\
\text { Religião Christãa por du- } \\
\text { zentos e oitenta reis } \$ 280\end{array}$ & $\begin{array}{l}\text { CHATEAUBRIAND, F. A. Os martyres, ou triumpho da re- } \\
\text { ligião christan / poema de F. A. de Chateaubriand; tradu- } \\
\text { zido em versos portuguezes por Francisco Manoel. Paris: } \\
\text { em casa de Rey e Gravier, } 1819,2 \text { vol., in- } 8,20 \mathrm{~cm} \text {. }\end{array}$ \\
\hline $\begin{array}{l}95 \\
F\end{array}$ & $\begin{array}{l}\text { Elementos da historia geral, } \\
\text { onze volumes por quatro } \\
\text { mil reis } 4 \$ 000\end{array}$ & $\begin{array}{l}\text { MILLOT, Claude François Xavier. Éléments d'histoire gé- } \\
\text { nérale ancienne et moderne; nouv. édit., continuée depuis } \\
\text { la paix de } 1763 \text { jusqu'à l'établissement du consulat en } \\
\text { France; par De Lisle De Sales. Paris, } 1809,11 \text { vol., in-12. }\end{array}$ \\
\hline $\begin{array}{l}96 \\
F\end{array}$ & $\begin{array}{l}\text { As comedias de Teren [fl. } \\
43] \text { de Terencio com Tra- } \\
\text { ducção de Madame Dacier } \\
\text { avaliada por mil duzentos e } \\
\text { oitenta reis } 1 \$ 280\end{array}$ & $\begin{array}{l}\text { TERÊNCIO. Les comédies de Terence. Traduites en fran- } \\
\text { çois avec des remarques par Madame } D^{* * *} \text {. Paris: Deny } \\
\text { Thierry et Claude Barbin, } 1688,3 \text { vol., in-12. } \\
\text { As traduções de Dacier foram reproduzidas muitas vezes } \\
\text { ao longo do século XVIII. }\end{array}$ \\
\hline & $127 \$ 400$ & \\
\hline $\begin{array}{l}97 \\
P\end{array}$ & $\begin{array}{l}\text { A choupana India avaliada } \\
\text { em duzentos e quarenta r.s } \\
\$ 240\end{array}$ & $\begin{array}{l}\text { SAINT-PIERRE, Henri Bernardin de. A choupana India: } \\
\text { escrita em francez pelo author de Paulo, e Virginia e verti- } \\
\text { da em portuguez. Lisboa: Typ. Rollandiana, 1806, XXXVI, } \\
85 \text { p., } 15 \mathrm{~cm} \text {. }\end{array}$ \\
\hline $\begin{array}{l}98 \\
F\end{array}$ & $\begin{array}{l}\text { Felicia, ou Mesfredams } \\
\text { (sic) tres volumes avaliados } \\
\text { por trezentos e vinte reis } \\
\$ 320\end{array}$ & $\begin{array}{l}\text { NERCIAT, Andrea de. Félicia ou mes fredaines. [Amster- } \\
\text { dam]: [s.n.], 1778, } 4 \text { t. em } 1 \text { vol., [16] f. est., } 17 \mathrm{~cm} \text {. }\end{array}$ \\
\hline $\begin{array}{l}99 \\
F\end{array}$ & $\begin{array}{l}\text { Consideração sobre a cau- } \\
\text { sa das grandezas dos Ro- } \\
\text { manos por trezentos e vinte } \\
\text { reis } \$ 320\end{array}$ & $\begin{array}{l}\text { MONTESQUIEU. Considérations sur les causes de la gran- } \\
\text { deur des romains et de leur décadence. Paris: Pierre Didot, } \\
\text { 1815. Há segunda edição: Paris: Librarie de Lerointe, } 1830 .\end{array}$ \\
\hline $\begin{array}{l}100 \\
F\end{array}$ & $\begin{array}{l}\text { O Imperio das Leis por } \\
\text { Montesqieu (sic) cinco vo- } \\
\text { lumes por mil novecentos e } \\
\text { vinte } 1 \$ 920\end{array}$ & $\begin{array}{l}\text { MONTESQUIEU. De l'esprit des lois. Paris: Pierre Didot l'ai- } \\
\text { ne,etFirminDidot, } 1803,(4)+277,290,246,264,266 \text { p., in-12. }\end{array}$ \\
\hline $\begin{array}{l}101 \\
F\end{array}$ & $\begin{array}{l}\text { Lettres Persanes por Mon- } \\
\text { tesquieu dois volumes por } \\
\text { mil duzentos e oitenta reis } \\
1 \$ 280\end{array}$ & $\begin{array}{l}\text { [MONTESQUIEU]. Lettres persanes. Amsterdam: Pierre } \\
\text { Brunel, } 1721,2 \text { vol., [1] } 311,[1] 347 \text { p., in-12. } \\
\text { A maior parte das impressões das Cartas persas saiu com } \\
\text { dois volumes e não pude precisar a edição. Por isso, indi- } \\
\text { quei a primeira edição. }\end{array}$ \\
\hline
\end{tabular}


rev. hist. (São Paulo), n. 171, p. 245-286, jul.-dez., 2014 http://dx.doi.org/10.11606/issn.2316-9141.rh.2014.89013
Pablo Antonio Iglesias Magalhães

Deus e o diabo na biblioteca de um cônego da Bahia: 0 inventário dos livros do padre Manoel Dendê Bus em 1836

\begin{tabular}{|c|c|c|}
\hline $\begin{array}{l}102 \\
F\end{array}$ & $\begin{array}{l}\text { La nouvelle Heloise ou let- } \\
\text { tres de deux amans seis } \\
\text { volumes avaliado por seis- } \\
\text { centos e quarenta reis } \$ 640\end{array}$ & $\begin{array}{l}\text { ROUSSEAU, Jean-Jacques. La nouvelle Héloise ou Let- } \\
\text { tres de deux amans habitans d'une petite ville au pied des } \\
\text { Alpes, rec. et publiées. Amsterdam, 1761, } 6 \text { vol., in-12. }\end{array}$ \\
\hline $\begin{array}{l}103 \\
P\end{array}$ & $\begin{array}{l}\text { Lusiadas de Camoens por } \\
\text { trezentos e vinte reis } \$ 320\end{array}$ & $\begin{array}{l}\text { CAMÕES, Luis de. Lusiadas / do grande Luis de Camo- } \\
\text { ens; com argumentos do licenciado Joao Franco Barreto } \\
\text { e index de todos os nomes próprios. Lisboa: por Antonio } \\
\text { Crasbeeck de Mello, 1670, [8], 469, [7] p., } 14 \mathrm{~cm} \text {, in-12. } \\
\text { CAMÕES, Luis de. Os Lusiadas / Do grande Luis de Ca- } \\
\text { moens, principe dos poetas de Hespanha, com os argu- } \\
\text { mentos do licenciado [I]oam Franco Barreto. Lisboa Occi- } \\
\text { dental: na Offic. Ferreyriana, 1721, [12], 896, [1]p., [1]f. de } \\
\text { estampa, retr., } 12 \mathrm{~cm} \text {, in-12. } \\
\text { São duas edições um tanto vulgares dos séculos XVII e } \\
\text { XVIII, respectivamente, que apresentam a grafia "Camo- } \\
\text { ens" na folha de rosto. }\end{array}$ \\
\hline $\begin{array}{l}104 \\
P\end{array}$ & 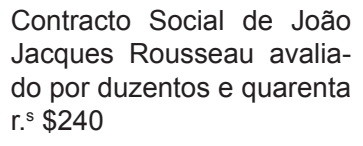 & $\begin{array}{l}\text { ROUSSEAU, J.-J. Contrato social ou princípios de direito } \\
\text { político. Lisboa: Typ. Rollandiana, } 1821,207 \text { p., } 21 \mathrm{~cm} \text {. }\end{array}$ \\
\hline $\begin{array}{l}105 \\
P\end{array}$ & $\begin{array}{l}\text { Contracto Social do dit- } \\
\text { to Rousseau por B. L. Vi } \\
\text { [fl. } 43 \mathrm{v} \text { ] L. Vianna avaliado } \\
\text { por duzentos e quarenta } \\
\text { reis } \$ 240\end{array}$ & $\begin{array}{l}\text { ROUSSEAU, J.-J. Contrato social, ou principios de direito } \\
\text { politico, de J. J. Rousseau; [trad.] por B. L. Viana. Paris: } \\
\text { na Officina de Firmino Didot, } 1821, \text { V, 325, [2] p.,14 cm. }\end{array}$ \\
\hline & $133 \$ 960$ & \\
\hline $\begin{array}{l}106 \\
L\end{array}$ & $\begin{array}{l}\text { Bíblia Sacra Vulgata edi- } \\
\text { tiones dois volumes in folio } \\
\text { por quatro mil reis } 4 \$ 000\end{array}$ & $\begin{array}{l}\text { DU HAMEL, J. B. Biblia Sacra Vulgatae Editionis, Sixti V. } \\
\text { et Clementis VIII. Pont. Max. auctoritate recognita, una } \\
\text { cum selectis annotationibus ex optimis quibusque inter- } \\
\text { pretibus excerptis, prolegomenis, novis tabulis chronolo- } \\
\text { gicis, historicis, et geographicis illustrata, indiceque epis- } \\
\text { tolarum et evangeliorum aucta. Auctore J. B. Du Hamel. } \\
\text { Paris, 1706, } 2 \text { vol., folio. }\end{array}$ \\
\hline $\begin{array}{l}107 \\
L\end{array}$ & $\begin{array}{l}\text { Sacrorum Bibliorum Vulga- } \\
\text { ta hum volume por dois mil } \\
\text { e quatrocentos } r .^{\text {s }} 2 \$ 400\end{array}$ & $\begin{array}{l}\text { LUCA, Francisco. Sacrorum bibliorum vulgatae editionis } \\
\text { concordantiae, ad recognitionem iussu Sixti V. Pont. Max. } \\
\text { / bibliis adhibitam recensitae atque emendatae primùm à } \\
\text { Francisco Luca...; nunc denuò variis locis expurgatae ac } \\
\text { locupletatae curâ \& studio V. D. Huberti Phalesii.... Antuér- } \\
\text { pia: ex Off. Plantiniana Balthasaris Moreti, } 1642 \text {. } \\
\text { Foram dezenas as edições da obra de Francisco Luca } \\
\text { (1549?-1619) publicados, em diversas cidades europeias, } \\
\text { entre os séculos XVI e XVIII. O exemplar em apreço é o } \\
\text { mais antigo da obra, encontrado na Biblioteca Nacional } \\
\text { de Portugal. }\end{array}$ \\
\hline
\end{tabular}


rev. hist. (São Paulo), n. 171, p. 245-286, jul.-dez., 2014 http://dx.doi.org/10.11606/issn.2316-9141.rh.2014.89013
Pablo Antonio Iglesias Magalhães

Deus e o diabo na biblioteca de um cônego da Bahia: 0 inventário dos livros do padre Manoel Dendê Bus em 1836

\begin{tabular}{|c|c|c|}
\hline $\begin{array}{l}108 \\
L\end{array}$ & $\begin{array}{l}\text { Homo Apostolicus por no- } \\
\text { vecentos e sessenta r. } \\
\$ 960\end{array}$ & $\begin{array}{l}\text { LIGORIO, Alfonso de. Homo apostolicus: instructus in sua } \\
\text { vocatione ad audiendas confessiones.../D. Alphonso de Li- } \\
\text { gorio....Ed.quarta. Bassani; Venetiis:apudRemondini, } 1777 . \\
\text { Homo apostolicus instructus in sua vocatione ad audien- } \\
\text { das confessiones, sive prareis, et instructio confessario- } \\
\text { rum.... Editio quinta. Bassani: Venetiis apud Remondini. } \\
1782,25 \mathrm{~cm} \text {. }\end{array}$ \\
\hline $\begin{array}{l}109 \\
F\end{array}$ & $\begin{array}{l}\text { Les inconveniens du celibat } \\
\text { avaliado por oitocentos reis } \\
\$ 800\end{array}$ & $\begin{array}{l}\text { GAUDIN, Jacques Maurice. Lesinconvéniens du célibatdes } \\
\text { pêtres, prouvés par des recherches historiques. [par l'abbé } \\
\text { Gaudin]. Genève: chez J. L. Pellet, M. DCC. LXXXI, } 1781 . \\
\text { Nouvelle édition [Paris: Lejay], } 1790 .\end{array}$ \\
\hline $\begin{array}{l}110 \\
L\end{array}$ & $\begin{array}{l}\text { Casus Conscientiae de } \\
\text { Mandato hum volume info- } \\
\text { lio avaliado por mil nove- } \\
\text { centos e vinte reis } 1 \$ 920\end{array}$ & $\begin{array}{l}\text { Casus conscientiae de mandato olim... Tit. S. Crucis in } \\
\text { Hierusalem S. E. R. presb. card. Prosperi Lambertini bo- } \\
\text { noniae archiepiscopi ac S. R. I. principis de inde Sanc- } \\
\text { tissimi... Papae Benedicti XIV propositi atque resoluti... } \\
\text { Ferrariae: expensis Bartholomaei Occhi, } 1764 .\end{array}$ \\
\hline $\begin{array}{l}111 \\
\mathrm{D}\end{array}$ & $\begin{array}{l}\text { Promptuaire de La Theologie } \\
\text { Moral avaliado por novecen- } \\
\text { tos e sessenta reis } \$ 960\end{array}$ & $\begin{array}{l}\text { A descrição do título indica uma tradução francesa da } \\
\text { obra de Francisco Larraga, mas não pude ver qualquer } \\
\text { referência a esta suposta tradução. }\end{array}$ \\
\hline $\begin{array}{l}112 \\
\mathrm{~L}\end{array}$ & $\begin{array}{l}\text { Breviarium Romanum ava- } \\
\text { liado por novecentos e ses- } \\
\text { senta reis } \$ 960\end{array}$ & $\begin{array}{l}\text { Breviarium Romanum Ex Decreto Sacrosancti Concilii Tri- } \\
\text { dentini restitutum. S. Pij V. Pont. Max. Jussu editum, Cle- } \\
\text { mentis VIII. et Urbani VIII. PP. auctoritate recognitum, \& } \\
\text { novis officiis, quae indulto apostolico universis singulisque } \\
\text { Fidelissimorum Lusitaniae Regum Ditionibus huc usque } \\
\text { sunt concessa, nunc denuò auctum: pars Aestiva. Olisi- } \\
\text { pone: in Typographia Regia, 1786, LXVI, 700, CCXLII, } 55 \\
\text { p., } 8^{\circ}, 19 \mathrm{~cm} \text {. } \\
\text { Breviarium romanum, ex. decr. sacrosancti conc. Trid. ref- } \\
\text { titutum; S. Pii V - Pont. maximi. Olisipone: in Typographia } \\
\text { Regia, } 1791,692 \text { p. de XXXVI e } 110 \text { p., } 19 \mathrm{~cm} \text {. } \\
\text { Breviarium romanum. EX. Decr. Sacrosanti Conc. Trid. } \\
\text { restitutum; S. Pii V. Pontif. Maximi lussu editum; Clemen- } \\
\text { tis VIII, et Urbani VIII. Auctoritate recognitum; cum officiis } \\
\text { nuperrime auctis, ac universis Ditionibus Fidelissimorum } \\
\text { Lusitaniae Regnum huc usque pro utroque clero conoes- } \\
\text { sis Locupletatum... Pars Verna,.... Olisipone: Typografia } \\
\text { Regia, } 1815, \text { XXXI, } 363 \text { p., il., } 19 \mathrm{~cm} \text {. }\end{array}$ \\
\hline $\begin{array}{l}113 \\
L\end{array}$ & $\begin{array}{l}\text { Breviarium Romanum ava- } \\
\text { liado por novecentos e ses- } \\
\text { senta reis } \$ 960\end{array}$ & $\begin{array}{l}\text { Os breviários romanos começaram a ser impressos logo } \\
\text { após o advento da imprensa, ainda no século XV. Assim, } \\
\text { nãoé possível identificar a edição. Cogitamos, contudo, que } \\
\text { os dois exemplares que Dendê Bus possuía tenham saído } \\
\text { dos prelos da Impressão Régia de Lisboa, que publicou pelo } \\
\text { menos três edições entre } 1786 \text { e 1815, acima indicados. }\end{array}$ \\
\hline
\end{tabular}


rev. hist. (São Paulo), n. 171, p. 245-286, jul.-dez., 2014 http://dx.doi.org/10.11606/issn.2316-9141.rh.2014.89013
Pablo Antonio Iglesias Magalhães

Deus e o diabo na biblioteca de um cônego da Bahia: 0 inventário dos livros do padre Manoel Dendê Bus em 1836

\begin{tabular}{|c|c|c|}
\hline $\begin{array}{l}114 \\
P\end{array}$ & $\begin{array}{l}\text { Tentativa Theologica hum } \\
\text { volume em quarto [fl. } 44 \text { ] } \\
\text { em quarto por dois mil reis. } \\
2 \$ 000\end{array}$ & $\begin{array}{l}\text { PEREIRA, Antonio. Tentativa theologica em que se pre- } \\
\text { tende mostrar que, impedido o recurso à Sé Apostolica, } \\
\text { se devolve aos senhores bispos a faculdade de dispensar } \\
\text { nos impedimentos publicos do matrimonio, e de prover } \\
\text { espiritualmente em todos os mais cazos reservados ao } \\
\text { papa. Lisboa: na Officina de Miguel Rodrigues, 1766, [48], } \\
\text { XI, } 286,[46] \text { p., in- } 4,22 \mathrm{~cm} \text {. Teve segunda edição na mes- } \\
\text { ma oficina e no mesmo ano. } \\
\text { 3. ed. emendada. Lisboa: na Officina de Antonio Rodri- } \\
\text { gues Galhardo, } 1769,[46], \mathrm{XI}, 286,[44], 62 \text { p., in-4, } 23 \mathrm{~cm} \text {. }\end{array}$ \\
\hline & $147 \$ 160$ & \\
\hline $\begin{array}{l}115 \\
\mathrm{~L}\end{array}$ & $\begin{array}{l}\text { Baptisterium et cerimoniale } \\
\text { avaliado por novecentos e } \\
\text { sessenta reis } \$ 960\end{array}$ & $\begin{array}{l}\text { Baptisterium, et caeremoniale sacramentorum justa ritum } \\
\text { Sanctae Romanae Ecclesiae, et rituale Pauli V. Ad usum } \\
\text { fere omnium ecclesiarum dominiorum Lusitaniae... In hac } \\
\text { nova editione accurate correctione.... Olisipone: Typis Si- } \\
\text { monis Thaddadi Ferreira, } 1785,1 \text { vol., in-4. } \\
\text { Há mais quatro edições conservadas na BNPT: } \\
\text { Olisipone: Typ. Simonis Thaddaei Ferreira, 1801, [6], } 143 \\
\text { [3] p., } 20 \mathrm{~cm} \text {. Olisipone: Typis Simonis Thaddaei Ferreriae, } \\
\text { 1817, [3 fl.], } 143 \text { [1] p. [1 fl.], } 22 \mathrm{~cm} \text {. Olisipone: ex Typogra- } \\
\text { fia Regia, 1828, [3 fl.], } 144 \text { p. [1 fl.], } 21 \mathrm{~cm} \text {. }\end{array}$ \\
\hline $\begin{array}{l}116 \\
\mathrm{~L}\end{array}$ & $\begin{array}{l}\text { Rituale breve ad Clericorum } \\
\text { avaliado por novecentos e } \\
\text { sessenta reis } \$ 960\end{array}$ & $\begin{array}{l}\text { Rituale breve ad clericorum, maxime parochorum, usum } \\
\text { perutile: non solùm Sacramentórum administratiónem, } \\
\text { sed étiem ómnium sere absolutiónum impertiónem. Editio } \\
\text { octava, auctior et accuratior. Olisipone: Ex Typographia } \\
\text { Regia, } 1830, \text { XII, } 552 \text { p., } 14 \mathrm{~cm} \text {. }\end{array}$ \\
\hline $\begin{array}{l}117 \\
P\end{array}$ & $\begin{array}{l}\text { Instituiçoens de cerimônias } \\
\text { avaliadas por quatrocentos } \\
\text { e oitenta reis } \$ 480\end{array}$ & $\begin{array}{l}\text { Instrucção de Ceremonias... mode de celebrae o sacrificio } \\
\text { da missa. / D. C. D. M. Lisboa: Regia Officina Tipografia, } \\
1782,1 \text { vol., } 15 \mathrm{~cm} \text {. } \\
\text { Instrucção de ceremónias em que se expõe o modo de } \\
\text { celebrar o sacrosanto sacrificio da missa assim rezada, } \\
\text { como cantada, conforme as rubricas do missal romano, } \\
\text { decretos da congregação dos ritos, e doutrina dos me- } \\
\text { Ihores authores / por hum sacerdote } D . C \text {. D. M. } 6^{\mathrm{a}} \text { ed. } \\
\text { Lisboa: António Rodrigues Galhardo, } 1804, \mathrm{XXVIII-406} \mathrm{p.,} \\
1 \text { desdobrável, } 15 \mathrm{~cm} \text {. }\end{array}$ \\
\hline $\begin{array}{l}118 \\
P\end{array}$ & $\begin{array}{l}\text { Hum Ritual Romano por } \\
\text { seiscentos e quarenta r.s } \\
\$ 640\end{array}$ & $\begin{array}{l}\text { MOURA, José Luiz Gomes de. Ritual das exequias ex- } \\
\text { trahido do ritual romano (...): a qual se ajunta a missa de } \\
\text { requiem com os seus ritos (...) / Pelo padre Luiz Gomes } \\
\text { de Moura. Lisboa: Regia Officina Typografica, } 1782 \text {, [4 fl.], } \\
232 \text { p., il., } 20 \mathrm{~cm} .2^{\mathrm{a}} \text { ed. correcta e acrescentada. Lisboa: } \\
\text { Regia Officina Typografica, } 1796,8,268 \text { p., } 20 \mathrm{~cm} \text {. } \\
\text { Ritual das exequias, extrahido do ritual romano, illustra- } \\
\text { do com duas pastoraes de dous bispos de Coimbra... I } \\
\text { pelo padre José Luiz Gomes de Moura... Terceira edição } \\
\text { novamente correcta, e accrescentada com huma missa } \\
\text { solemne. Lisboa: na Impressão Imperial e Real, } 1825 \text {, [8], } \\
280 \text { p., not. mus., } 4^{\circ}, 20 \mathrm{~cm} \text {. }\end{array}$ \\
\hline $\begin{array}{l}119 \\
P\end{array}$ & $\begin{array}{l}\text { Collecção de bênçãos Eccle- } \\
\text { siasticas avaliada por seis- } \\
\text { centos e quarenta reis } \$ 640\end{array}$ & $\begin{array}{l}\text { Collecção de bençaos ecclesisticas, approvadas pela } \\
\text { santa igreja catholica romana e destinadas para santificar } \\
\text { tudo o que he necessario para o culto divino, e para uso } \\
\text { commum das creaturas. Porto: Oficina de Antonio Alvarez } \\
\text { Ribeiro, } 1797, \text { XVI-476 p. }\end{array}$ \\
\hline
\end{tabular}


rev. hist. (São Paulo), n. 171, p. 245-286, jul.-dez., 2014 http://dx.doi.org/10.11606/issn.2316-9141.rh.2014.89013
Pablo Antonio Iglesias Magalhães

Deus e o diabo na biblioteca de um cônego da Bahia: 0 inventário dos livros do padre Manoel Dendê Bus em 1836

\begin{tabular}{|c|c|c|}
\hline $\begin{array}{l}120 \\
P\end{array}$ & $\begin{array}{l}\text { Do enfermo assistido na } \\
\text { ultima doença com todos } \\
\text { os socorros espirituaes por } \\
\text { seiscentos e quarenta reis } \\
\$ 640\end{array}$ & $\begin{array}{l}\text { CAMPOS, Francisco José. O enfermo assistido na sua } \\
\text { ultima doença com todos os socorros espirituaes. Lisboa: } \\
\text { Regia of. tipográfica, } 1775,13 \mathrm{~cm} \text {. }\end{array}$ \\
\hline $\begin{array}{l}121 \\
P\end{array}$ & $\begin{array}{l}\text { Theatro Ecclesiastico dois } \\
\text { volumes em quarto por tres } \\
\text { mil e duzentos reis } 3 \$ 200\end{array}$ & $\begin{array}{l}\text { ROSARIO, Domingos do. Theatro ecclesiastico em que } \\
\text { se achão muitos documentos de canto-chão para qual- } \\
\text { quer pessoa dedicada ao culto divino nos officios do coro, } \\
\text { e altar... / ordenado por seu author o padre fr. Domingos } \\
\text { do Rosario...; Dado ao prélo pelo... senhor duque do Ca- } \\
\text { daval.... Oitava impressão. Lisboa: na Officina de Simão } \\
\text { Thaddeo Ferreira, } 1786,2 \text { vol., in- } 4,21 \mathrm{~cm} \text {. } \\
\text { Theatro ecclesiastico em que se acham muitos documen- } \\
\text { tos de canto-chão para qualquer pessoa dedicada ao cul- } \\
\text { to divino nos officios do coro, e altar... Música impressa / } \\
\text { ordenado por seu author o padre fr. Domingos do Rosa- } \\
\text { rio...; dado ao prélo pelo senhor d. José de Mello, prior } \\
\text { mór de Palmella. } 9^{a} \text { impressão. Lisboa: na Impressão Re- } \\
\text { gia, } 1817,2 \text { vol. in- } 4,20 \mathrm{~cm} \text {. } \\
\text { Esse livro foi impresso em dois volumes, conforme descrito } \\
\text { no inventário, somente na oitava e nona edição. }\end{array}$ \\
\hline $\begin{array}{l}122 \\
L\end{array}$ & $\begin{array}{l}\text { Concilium Tridentinum ava- } \\
\text { liado por duzentos e qua- } \\
\text { renta reis } \$ 240\end{array}$ & $\begin{array}{l}\text { GALLEMART, Joannis. Concilium tridentinum, cum decla- } \\
\text { rationibus cardinalium ejusdem interpretum et ultima re- } \\
\text { cognitione Joannis Gallemart. Editio novissima... cui per- } \\
\text { multas constitutiones pontificum ad varia concilii capita et } \\
\text { appendicem propositionum usque Clementem XIV appo- } \\
\text { suit Aloysius Guerra. Venetiis: Sumptibus heredis Nicolai } \\
\text { Pezzana, } 1780 \text {, in- } 4 \text {. } \\
\text { Há diversas edições do Concílio Tridentino, mas exem- } \\
\text { plares da obra acima foram trazidos para o Brasil, como } \\
\text { consta no estudo de Gilda Maria Verri. }\end{array}$ \\
\hline $\begin{array}{l}123 \\
P\end{array}$ & $\begin{array}{l}\text { Opusculo Theologico das } \\
\text { instituiçoens (sic) avaliado } \\
\text { [fl. } 44 \mathrm{v} \text { ] avaliado por seis- } \\
\text { centos e quarenta reis } \$ 640\end{array}$ & $\begin{array}{l}\text { FERREIRA, Antonio. Opusculo theologico das constitui- } \\
\text { ções ou bullas, cartas circulares e decretos apostolicos do } \\
\text { santissimo padre Benedicto papa XIV... / composto pelo } \\
\text { licenciado Antonio Ferreira. Coimbra: na Officina de Luis } \\
\text { Secco Ferreira, } 1759,543 \text { p., in- } 4,21 \mathrm{~cm} \text {. }\end{array}$ \\
\hline & $156 \$ 920$ & \\
\hline $\begin{array}{l}124 \\
L\end{array}$ & $\begin{array}{l}\text { Gmeineri Xav. Institutiones } \\
\text { Júris Ecclesiastici avaliado } \\
\text { por mil reis } 1 \$ 000\end{array}$ & $\begin{array}{l}\text { GMEINER, Franz Xavier. Gmeineri Xav institutiones iuris } \\
\text { ecclesiastici ad principia iuris naturae et civitatis methodo } \\
\text { scientifica adornatae et germaniae adcomodatae. Venetiis: } \\
\text { sumptibus Francisci ex Nicolao Pezzana, } 1783,2 \text { vol., in- } 4 \text {. }\end{array}$ \\
\hline $\begin{array}{l}125 \\
L\end{array}$ & $\begin{array}{l}\text { Flores Bibliorum por seis- } \\
\text { centos e quarenta reis } \$ 640\end{array}$ & $\begin{array}{l}\text { PALMERANUS, Thomas. Flores bibliorum; sive loci } \\
\text { communes omnium fere materiarum, ex veteri ac Novo } \\
\text { Testamento decerpti: alphabetico ordine digesti, ac casti- } \\
\text { gati. [Wien]: Kraus, } 1753 \text {. } \\
\text { Livro que foi muitas vezes impresso desde o século XVI. }\end{array}$ \\
\hline
\end{tabular}


rev. hist. (São Paulo), n. 171, p. 245-286, jul.-dez., 2014 http://dx.doi.org/10.11606/issn.2316-9141.rh.2014.89013
Pablo Antonio Iglesias Magalhães

Deus e o diabo na biblioteca de um cônego da Bahia: 0 inventário dos livros do padre Manoel Dendê Bus em 1836

\begin{tabular}{|c|c|c|}
\hline $\begin{array}{l}126 \\
F\end{array}$ & $\begin{array}{l}\text { Diccionario Apostólico qua- } \\
\text { torze volumes em oitavo } \\
\text { por oito mil reis } \$ 640\end{array}$ & $\begin{array}{l}\text { MONTARGON, Jacinto de. Dictionnaire apostolique a } \\
\text { l'usage de... les curés des villes et de la Campagne... / } \\
\text { Hyacinthe de Montargon. Paris: chez A. M. Lottin, 1776, } \\
14 \text { vol., } 17 \mathrm{~cm} \text {. } \\
\text { Dictionnaire apostolique, a l'usage de M. M. les curés des } \\
\text { villes et de la campagne... / Par le P. Hyacinthe de Montar- } \\
\text { gon.... Lyon: Bruyset Freres, } 1787,14 \text { vol., } 17 \mathrm{~cm} \text {. } \\
\text { A primeria edição de Paris, impressa por A. M. Lottin, teve } \\
13 \text { volumes, mas as duas subsequentes tiveram } 14 \text { volu- } \\
\text { mes, devendo ser uma dessas a do inventário. }\end{array}$ \\
\hline $\begin{array}{l}127 \\
P\end{array}$ & $\begin{array}{l}\text { Discurso sobre a historia } \\
\text { Ecclesiastica avaliado por } \\
\text { novecentos e sessenta reis } \\
\$ 960\end{array}$ & $\begin{array}{l}\text { BARRETO, Luiz Carlos Moniz. Tradução. Discursos sobre } \\
\text { a historia ecclesiastica / por mr. o abbade Fleury...; expos- } \\
\text { to tudo na lingua portugueza, e offerecido ao excellent. e } \\
\text { rever. senhor d. fr. Manoel do Cenaculo, bispo de Beja, do } \\
\text { Conselho de sua magestade... pelo bacharel Luiz Carlos } \\
\text { Moniz Barreto. Nova edicçam. Lisboa: na Officina de An- } \\
\text { tonio Vicente da Silva, a custa de Luiz Antonio Alfeiraõ, } \\
1773,3 \text { vol. ([26], } 309 \text { p.), } 268 \text { p., (342, [2] p.), } 8^{\circ}, 17 \mathrm{~cm} \text {. } \\
\text { FLEURY, Claude. Discursos sobre a historia ecclesiastica } \\
\text { augmentada dos discursos sobre a poezia dos hebrêos, } \\
\text { sobre a escriptura santa, sobre a prégação sobre as liber- } \\
\text { dades da igreja gallicana. [S. I.: s. n. 18--], } 1 \text { vol. } \\
\text { A BNPT possui um exemplar dos Discursos de Fleury, aci- } \\
\text { ma descrito, em um volume, sob o registro TR. } 4484 \text { P. }\end{array}$ \\
\hline $\begin{array}{l}128 \\
F\end{array}$ & $\begin{array}{l}\text { Tenses (sic) Ecclesiasti- } \\
\text { ques por oitocentos reis } \\
\$ 800\end{array}$ & $\begin{array}{l}\text { CARRON, Guy Toussaint Julien. Pensees ecclesiastiques } \\
\text { pour tous les jours de l'annee: recueillies par un pretre } \\
\text { francois exile pour la foi. Londres: de l'imprimerie de } \\
\text { Baylis, se trouve chez l'auteur. A. Dulau \& Co. P. Huard \& } \\
\text { Fougere, } 1799,3 \text { vol., in-12. }\end{array}$ \\
\hline $\begin{array}{l}129 \\
F\end{array}$ & $\begin{array}{l}\text { O Ecclesiastico a cumprir o } \\
\text { plano de huma vida verda- } \\
\text { deiramente saira avaliado } \\
\text { por duzentos reis } \$ 200\end{array}$ & 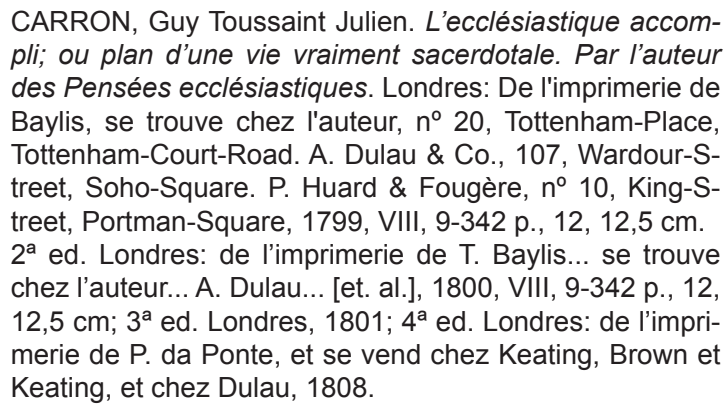 \\
\hline $\begin{array}{l}130 \\
P\end{array}$ & $\begin{array}{l}\text { A Religião provada pela } \\
\text { revolução avaliado por du- } \\
\text { zentos e quarenta reis } \$ 240\end{array}$ & $\begin{array}{l}\text { MONTALS, Clausel. A religião provada pela revolução, } \\
\text { ou exposição das prevenções decisivas, que a favor do } \\
\text { cristianismo resultão da revolução, de suas causas e de } \\
\text { seus efeitos / Pelo abbade Clausel de Montals; Trad. por } \\
\text { Joaquim José Pedro Lopes. Lisboa: Impr. Régia, 1819, } \\
308 \text { p., } 14 \mathrm{~cm}\end{array}$ \\
\hline $\begin{array}{l}131 \\
P\end{array}$ & $\begin{array}{l}\text { Diccionario abbreviado da } \\
\text { Biblia por trezentos e vinte } \\
\text { reis } \$ 320\end{array}$ & $\begin{array}{l}\text { Diccionario abbreviado da Biblia. } 2^{a} \text { ed. correcta e emen- } \\
\text { dada. Lisboa: Typ. Rollandiana, } 1794.419 \text { p., } 16 \mathrm{~cm} \text {. }\end{array}$ \\
\hline
\end{tabular}


rev. hist. (São Paulo), n. 171, p. 245-286, jul.-dez., 2014 http://dx.doi.org/10.11606/issn.2316-9141.rh.2014.89013
Pablo Antonio Iglesias Magalhães

Deus e o diabo na biblioteca de um cônego da Bahia: 0 inventário dos livros do padre Manoel Dendê Bus em 1836

\begin{tabular}{|c|c|c|}
\hline $\begin{array}{l}132 \\
P\end{array}$ & $\begin{array}{l}\text { Compendio da vida do Ve- } \\
\text { neravel João Gerson, Ava } \\
\text { [fl. 45] Gerson, avaliado por } \\
\text { quatrocentos reis } \$ 400\end{array}$ & $\begin{array}{l}\text { FIGUEIREDO, Antonio Pereira de. Compendio da vida e } \\
\text { acçoens do veneravel Joaõ Gerson cancellario da Univer- } \\
\text { sidade de Pariz, chamado por Antonomasia o doutor chris- } \\
\text { tianissimo / Antonio Pereira de Figueiredo. Lisboa: na Offi- } \\
\text { cina de Antonio Vicente da Silva, 1769, [22], } 231 \text { p., } 14 \mathrm{~cm} \text {. }\end{array}$ \\
\hline & $169 \$ 720$ & \\
\hline $\begin{array}{l}133 \\
E\end{array}$ & $\begin{array}{l}\text { Quaresma do Padre Paulo } \\
\text { Feneri (sic) avaliado por } \\
\text { trezentos e vinte reis } \$ 320\end{array}$ & $\begin{array}{l}\text { SEGNERI, Paolo. Quaresma. Tradução por el dr. António } \\
\text { de Las Casas. Barcelona: Imp. de Juan Piferrer, 1724, } 521 \\
+3 \text { p., } 21 \mathrm{~cm} \text {. } \\
\text { Não encontrei traduções portuguesas da obra Quaresi- } \\
\text { male, publicada originalmente em } 1674 \text {. Mas há diversas } \\
\text { traduções espanholas da obra de "Pablo Señeri": Madri: } \\
\text { Francisco Lasso, } 1717 \text {. Traducidos del idioma toscano en } \\
\text { castellano por Antonio de las Casas, } 2 \text { vol., } 452,421 \text { p., } 20 \\
\text { x } 15 \mathrm{~cm} \text {. E Madri: en la imprenta de Jayme Osset, } 1765 \text {, } \\
2 \text { vol., } 415,408 \text { p., in-8. Duas edições de Barcelona, con- } \\
\text { tudo, foram editadas em volume único. A Biblioteca Na- } \\
\text { cional da Espanha conserva um exemplar sem data, local } \\
\text { e impressor, mas que é da Imprensa de Pedro Escuder, } \\
\text { Barcelona. Por isso, penso que um desses impressos ca- } \\
\text { talães constituía o exemplar indicado no inventário. }\end{array}$ \\
\hline $\begin{array}{l}134 \\
F\end{array}$ & $\begin{array}{l}\text { Trones (sic) de Claude Joli } \\
\text { por oitocentos reis } \$ 800\end{array}$ & $\begin{array}{l}\text { JOLY, Claude. Prones de messire Claude Joli, eveque et } \\
\text { comte d'Agen pour tous les dimanches de l'année. Bruxe- } \\
\text { las: chez François Foppens, } 1696 \text {. } \\
\text { Outraedição:Paris:chezDenisMariette...,M.DCC.XII.,1712. }\end{array}$ \\
\hline $\begin{array}{l}135 \\
P\end{array}$ & 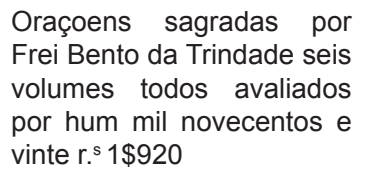 & $\begin{array}{l}\text { TRINDADE, fr. Bento da. Orações sagradas: offerecidas } \\
\text { ao... senhor d. João, principe regente. Lisboa: Of. J. F. M. } \\
\text { de Campos, } 1817,6 \text { t., } 15 \mathrm{~cm} \text {. }\end{array}$ \\
\hline $\begin{array}{l}136 \\
D\end{array}$ & $\begin{array}{l}\text { Sermoens varios avaliado o } \\
\text { volume por trezentos e vin- } \\
\text { te reis } \$ 320\end{array}$ & $\begin{array}{l}\text { Esse item parece tratar-se de um códice factício com al- } \\
\text { guns sermões encadernados juntos. }\end{array}$ \\
\hline $\begin{array}{l}137 \\
P\end{array}$ & $\begin{array}{l}\text { Colleção dos melhores ser- } \\
\text { moens seis volumes trun- } \\
\text { cados por novecentos e } \\
\text { sessenta r.s } \$ 960\end{array}$ & $\begin{array}{l}\text { Collecção dos melhores sermões escolhidos dos mais ce- } \\
\text { lebres pregadores, que de França, e Italia até agora tem } \\
\text { chegado ao nosso Reino (...) Tambem dos melhores ora- } \\
\text { dores nacionaes. Lisboa: na Regia Officina Typografica, } \\
1777-1781,10 \text { vol., } 15 \mathrm{~cm} \text {. } \\
\text { Nãoencontrei essa coleção em nenhuma biblioteca pública, } \\
\text { mas existe a referência no Catálogo da Biblioteca Amorim } \\
\text { Pessoa. Coimbra: Editora da Universidade, } 1989, n^{\circ} 528 . \\
\text { Pela descrição no inventário, faltavam quatro volumes. }\end{array}$ \\
\hline $\begin{array}{l}138 \\
P\end{array}$ & $\begin{array}{l}\text { Sermoens novos traduzidos } \\
\text { do Francez avaliado por tre- } \\
\text { zentos e vinte reis } \$ 320\end{array}$ & $\begin{array}{l}\text { ALFEIRÃO, Luiz António (ed.). Sermões novos. Lisboa: } \\
\text { Of. de João António da Silva, } 1775,3 \text { vol., } 19 \mathrm{~cm} \text {. }\end{array}$ \\
\hline
\end{tabular}


rev. hist. (São Paulo), n. 171, p. 245-286, jul.-dez., 2014 http://dx.doi.org/10.11606/issn.2316-9141.rh.2014.89013
Pablo Antonio Iglesias Magalhães

Deus e o diabo na biblioteca de um cônego da Bahia: 0 inventário dos livros do padre Manoel Dendê Bus em 1836

\begin{tabular}{|c|c|c|}
\hline $\begin{array}{l}139 \\
P\end{array}$ & $\begin{array}{l}\text { Panegiricos e Discursos } \\
\text { Evangelicos dois volumes } \\
\text { por duzentos e quarenta } \\
\text { reis } \$ 240\end{array}$ & $\begin{array}{l}\text { Panegyricos e discursos evangelicos: recopilados, e tra- } \\
\text { duzidos dos melhores oradores francezes, e italianos. Lis- } \\
\text { boa: Typ. Rollandiana, } 1784 \text { e } 1785,2 \text { vol., } 15 \mathrm{~cm} \text {. }\end{array}$ \\
\hline $\begin{array}{l}140 \\
P\end{array}$ & $\begin{array}{l}\text { Sermoens, e panegiricos } \\
\text { selectos tres volumes por } \\
\text { duzentos e quarenta reis } \\
\$ 240\end{array}$ & $\begin{array}{l}\text { Sermões, e panegyricos selectos, extrahidos dos mais ce- } \\
\text { lebres authores nacionaes, e estrangeiros. Lisboa: na Of- } \\
\text { ficina de Lino da Silva Godinho - José de Aquino Bulhões, } \\
1784-1785,3 \text { vol., } 16 \mathrm{~cm} \text {. } \\
\text { Não encontrei essa coleção em nenhuma biblioteca pública, } \\
\text { mas existe a referência no Catálogo da Biblioteca Amorim } \\
\text { Pessoa. Coimbra: Editora da Universidade, } 1989, n^{\circ} 2009 .\end{array}$ \\
\hline \multirow[t]{2}{*}{$\begin{array}{l}141 \\
P\end{array}$} & $\begin{array}{l}\text { Promptuario de Theo [fl. } \\
45 \mathrm{v} \text { ] de Theologia moral } \\
\text { truncado avaliado por qua- } \\
\text { trocentos reis } \$ 400\end{array}$ & $\begin{array}{l}\text { Promptuario de theologia moral / composto primeiramente } \\
\text { pelo p. m. fr. Francisco Larraga...; reformado e accrescen- } \\
\text { tado... por d. Francisco Santos e Grosin. Lisboa: Off. de } \\
\text { Simäo Thaddeo Ferreira, } 1798,2 \text { vol., } 15 \mathrm{~cm} \text {. } \\
\text { Promptuario de theologia moral / composto primeiramente } \\
\text { pelo p. m. fr. Francisco Larraga...; reformado e emenda- } \\
\text { do... por Francisco dos Santos Grosin. } 2 \text { a ed. Porto: na Of. } \\
\text { de Antonio Alvarez Ribeiro, } 1803,3 \text { vol., } 17 \mathrm{~cm} \text {. } \\
\text { O Prontuário de Larraga foi amplamente impresso desde o } \\
\text { século XVII, especialmente em Portugal e Espanha, comu- } \\
\text { mente em um único volume. A informação de que o exem- } \\
\text { plar estava "truncado" revela que pode ter sido uma das edi- } \\
\text { ções acima indicadas, que saíram com mais de um volume. }\end{array}$ \\
\hline & $175 \$ 240$ & \\
\hline $\begin{array}{l}142 \\
L\end{array}$ & $\begin{array}{l}\text { R. P. Hernani hum volume } \\
\text { infolio muito usado por seis- } \\
\text { centos e quarenta reis } \$ 640\end{array}$ & $\begin{array}{l}\text { AFONSO MARIA DE LIGÓRIO, Santo. R. P. Hermanni } \\
\text { Busembaum Societatis Jesu Theologia moralis nunc pluri- } \\
\text { bus partibus aucta a R. P. D. Alphonso de Ligorio. Romae: } \\
\text { Sumptibus Remondinianis, MDCCLVII, XIII-[15]-LX-262, } \\
\text { XVI-287-[1], [8]-223-[1], } 36,5 \mathrm{~cm} \text {. } \\
\text { Pode tratar-se de um item truncado. }\end{array}$ \\
\hline $\begin{array}{l}143 \\
P\end{array}$ & $\begin{array}{l}\text { Benedicto quatorze hum } \\
\text { volume avaliado por nove- } \\
\text { centos e sessenta reis } \$ 960\end{array}$ & $\begin{array}{l}\text { CARACCIOLI, Marquez. Elogio historico de Benedicto } \\
\text { XIV. Lisboa: na Regia Off. Typ., } 1769,61 \text { p., } 17 \mathrm{~cm} \text {. }\end{array}$ \\
\hline $\begin{array}{l}144 \\
L\end{array}$ & $\begin{array}{l}\text { Benediate casus conscien- } \\
\text { tia hum ditto avaliado por } \\
\text { novecentos e sessenta reis } \\
\$ 960\end{array}$ & $\begin{array}{l}\text { BENEDICTUS, Papa XIV. Casus conscientiae de manda- } \\
\text { to olim eminentissimi s. r. e. cardinalis Prosperi Lambertini } \\
\text { Bononiae archiepiscopi \&c. \&c. Deinde Sanctissimi d. } n \text {. } \\
\text { papae Benedicti XIV. Propositi ac resoluti: Opus confes- } \\
\text { sariis omnibus atque animarum curam gerentibus peru- } \\
\text { tile ac necessarium. ad casus conscientiae de mandato } \\
\text {... appendix novissima. Augustae Vindelicorum: Rieger, } \\
\text { 1762. Obra que teve reedições em 1764, } 1766 \text { etc. }\end{array}$ \\
\hline
\end{tabular}


rev. hist. (São Paulo), n. 171, p. 245-286, jul.-dez., 2014 http://dx.doi.org/10.11606/issn.2316-9141.rh.2014.89013
Pablo Antonio Iglesias Magalhães

Deus e 0 diabo na biblioteca de um cônego da Bahia: 0 inventário dos livros do padre Manoel Dendê Bus em 1836

\begin{tabular}{|c|c|c|}
\hline $\begin{array}{l}145 \\
\mathrm{~L}\end{array}$ & $\begin{array}{l}\text { Patuzzii Theologia por no- } \\
\text { vecentos e sessenta reis } \\
\$ 960\end{array}$ & $\begin{array}{l}\text { PATUZZI, Giovanni Vincenzo. Theologia dogmatico-mora- } \\
\text { lis quam clericis concinnavit Gaspar Vattolus J. U. D. in } \\
\text { seminario Utinensi studiorum præfectus. Roma: Prostant } \\
\text { Venetiis: apud Antonium Perlini, } 1764,653 \mathrm{p} \text {. }\end{array}$ \\
\hline $\begin{array}{l}146 \\
P\end{array}$ & $\begin{array}{l}\text { Historia dos Direitos Metro- } \\
\text { politanos de Portugal por } \\
\text { novecentos e sessenta reis } \\
\$ 960\end{array}$ & $\begin{array}{l}\text { FIGUEIREDO, António Pereira de. Demonstração theolo- } \\
\text { gica, canonica e historica, do direito dos metropolitanos } \\
\text { de Portugal para confirmarem, e mandarem sagrar os } \\
\text { bispos suffraganeos nomeados por sua magestade; e do } \\
\text { direito dos bispos de cada provincia para confirmarem e } \\
\text { sagrarem os seus respectivos metropolitanos tambem no- } \\
\text { meados por sua magestade ainda fora do caso de rotura } \\
\text { com a Corte de Roma. Lisboa: na Regia Officina Typogra- } \\
\text { fica, } 1769, \mathrm{XXIV}, 3,474 \mathrm{p} ., 22 \mathrm{~cm} \text {. }\end{array}$ \\
\hline $\begin{array}{l}147 \\
P\end{array}$ & 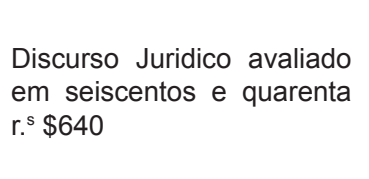 & $\begin{array}{l}\text { SOUSA, Manoel de Almeida e. Discurso juridico, historico } \\
\text { e critico sobre os direitos dominicaes e provas delles nes- } \\
\text { te reino em favor da corôa seus donatarios, e outros mais } \\
\text { senhorios particulares. Lisboa: Impressão Regia, } 1819 \text {, } \\
204 \text { p., } 22 \mathrm{~cm} \text {. }\end{array}$ \\
\hline $\begin{array}{l}148 \\
\mathrm{~L}\end{array}$ & $\begin{array}{l}\text { Quinti Horacii Flacii avalia- } \\
\text { do por mil e duzentos reis } \\
1 \$ 200\end{array}$ & $\begin{array}{l}\text { VEEN, Otto van. Quinti Horatii Flacci emblemata: imagini- } \\
\text { bus in aes incisis, notisque illustrata. Editio nova correc- } \\
\text { tior, \& ss. patrum, Senecae atque aliorum philosophorum } \\
\text { \& poëtarum sententiis, novisque versibus. Bruxelas: apud } \\
\text { Franciscum Foppens, bibliopolam, } 1683 \text {. } \\
\text { Penso tratar-se de uma das muitas edições Quinti Hora- } \\
\text { tii Flacci emblemata, que começam a ser publicadas em } \\
\text { 1612. Muitas apresentavam ilustrações, que justificam o } \\
\text { valor elevado atribuído a esta obra no inventário. }\end{array}$ \\
\hline $\begin{array}{l}149 \\
F / H\end{array}$ & $\begin{array}{l}\text { Diccionaire Ollandez ava- } \\
\text { liado por mil duzentos e oi- } \\
\text { tenta reis } 1 \$ 280\end{array}$ & $\begin{array}{l}\text { MARIN, Pieter. Dictionnaire françois et hollandois com- } \\
\text { prenant tous les mots de l'usage avouez de L'Académie } \\
\text { Françoise \& autres auteurs d'élite, exactement définis \& } \\
\text { clairement expliquez par des exemples qui découvrent le } \\
\text { véritable génie de l'une \& de l'autre langue. Cet ouvrage, } \\
\text { qui renferme aussi les termes d'arts les plus nécessaires, } \\
\text { est encore enrichi de plusieurs notes curieuses, remar- } \\
\text { ques historiques, \& autres choses capables de former le } \\
\text { got à la belle littérature. Par P. Marin = Fransch en Neder- } \\
\text { duitsch woorden-boek, behelsende alle gebruikelyke wo- } \\
\text { orden, door de Fransche Academie en andere uitgelezene } \\
\text { schryvers aangenomen, naauwkeuriglyk beschreven, en } \\
\text { door voorbeelden, die den regten aart der wederzydsche } \\
\text { taalen natuurlyk ontvouwen, klaarlyk uitgelegt. Dit werk, } \\
\text { waar in ook de noodzaakelykste konstwoorden den ver vat } \\
\text { zyn, is daar en boven noch verrykt met verscheide fraaye } \\
\text { aanteekeningen, historische aanmerkingen, en andere } \\
\text { zzaken bekwaam om de lust van den lezer tot cierlyke let- } \\
\text { terkennisse op te wekken. Amsterdam: Jan van Eyl; Rot- } \\
\text { terdam: Jan Daniel Beman en zoon, } 1762 \text {. } \\
\text { MARIN, Pieter. Dictionnaire portatif, françois et hollandois. } \\
\text { Dort: chez A. Blussé et fils, } 1773, \text { xxii, } 917 \text { p., } 19 \text { cm. Esse } \\
\text { valioso dicionário teve cinco edições até } 1782 \text {. }\end{array}$ \\
\hline
\end{tabular}


rev. hist. (São Paulo), n. 171, p. 245-286, jul.-dez., 2014 http://dx.doi.org/10.11606/issn.2316-9141.rh.2014.89013
Pablo Antonio Iglesias Magalhães

Deus e o diabo na biblioteca de um cônego da Bahia: 0 inventário dos livros do padre Manoel Dendê Bus em 1836

\begin{tabular}{|c|c|c|}
\hline $\begin{array}{l}150 \\
L\end{array}$ & $\begin{array}{l}\text { Homo Apostolicus avaliado } \\
\text { por seiscentos e quarenta } \\
\text { reis } \$ 640\end{array}$ & $\begin{array}{l}\text { LIGORIO, Alfonso de. Homo apostolicus: instructus in sua } \\
\text { vocatione ad audiendas confessiones... / D. Alphonso de } \\
\text { Ligorio.... Ed. quarta. Bassani. Venetiis: apud Remondini, } \\
1777,3 \text { t. em } 1 \text { vol. } \\
\text { Homo apostolicus instructus in sua vocatione ad audien- } \\
\text { das confessiones, sive prareis, et instructio confessario- } \\
\text { rum.... Editio quinta. Bassani: Venetiis: apud Remondini, } \\
1782,3 \text { vol. enc. juntos, } 25 \mathrm{~cm} \text {. }\end{array}$ \\
\hline \multirow[t]{2}{*}{$\begin{array}{l}151 \\
P\end{array}$} & $\begin{array}{l}\text { Parnaso Lusitano [fl. 46] } \\
\text { Lusitano quatro volumes } \\
\text { avaliados por mil e seiscen- } \\
\text { tos reis } 1 \$ 600\end{array}$ & $\begin{array}{l}\text { Parnaso lusitano ou poesias selectas dos auctores portu- } \\
\text { guezes antigos e modernos, illustradas com notas: prece- } \\
\text { dido de uma história abreviada da lingua e poezia portu- } \\
\text { gueza. Paris: J. P. Aillaud, } 1826,5 \text { vol., } 20 \mathrm{~cm} \text {. } \\
\text { A coleção, editada por J. B. d'Almeida Garrett, está trunca- } \\
\text { da, faltando dois volumes. }\end{array}$ \\
\hline & $183 \$ 960$ & \\
\hline $\begin{array}{l}152 \\
F\end{array}$ & $\begin{array}{l}\text { Tractado da leitura christãa } \\
\text { avaliado por quatrocentos e } \\
\text { oitenta reis } \$ 480\end{array}$ & $\begin{array}{l}\text { JAMIN, Nicolas. Traité de la lecture chrétienne, dans le- } \\
\text { quel on expose des règles propres à guider les fidèles } \\
\text { dans le choix des livres, et à les leur rendre utiles. Paris: } \\
\text { J.-F. Bastien, } 1774,404 \text { p., in- } 12 \text {. } \\
\text { Teve reedições em } 1776 \text { e } 1827 \text { e uma tradução alemã } \\
\text { de } 1780 .\end{array}$ \\
\hline 153 & $\begin{array}{l}\text { Vida de Hervay avaliado } \\
\text { por trezentos e vinte reis } \\
\$ 320\end{array}$ & $\begin{array}{l}\text { BROWN, John. Life of the rev. James Hervey, M. A. rector of } \\
\text { Weston-Favel.Londres: Religious TractSociety, } 1830,144 \mathrm{p} \text {. }\end{array}$ \\
\hline $\begin{array}{l}154 \\
F\end{array}$ & $\begin{array}{l}\text { Historia das varias soceço- } \\
\text { ens da Igreja trucada por } \\
\text { quatrocentos e oitenta reis } \\
\$ 480\end{array}$ & $\begin{array}{l}\text { BASNAGE, Jacques. Histoire de l'église depuis Jesus } \\
\text { Christ jusqu'à présent: divisée en quatre parties / par mons. } \\
\text { Basnage. Rotterdam: chez Reinier Leers, } 1699,2 \text { vol., fólio. } \\
\text { A parte quatro da obra acima tem o título de L'histoire de la } \\
\text { succession de l'Eglise, de son gouvernement, de ses princi- } \\
\text { paux dogmes \& de son culte, depuis l'onziéme siécle jusqu'à } \\
\text { présent. Como o inventário indica a obra truncada, portan- } \\
\text { to, sem o volume inicial, Lima registou apenas o subtítulo. }\end{array}$ \\
\hline $\begin{array}{l}155 \\
F\end{array}$ & $\begin{array}{l}\text { O Exame do materialismo } \\
\text { por oitocentos reis } \$ 800\end{array}$ & $\begin{array}{l}\text { BERGIER, Nicolas Sylvestre. Examen du matérialisme, } \\
\text { ou réfutation du systéme de la nature. Paris: chez Hum- } \\
\text { blot, } 1771,2 \text { vol., in- } 12 \text {. } \\
\text { Deconfio que este livro teve uma edição brasileira entre } \\
\text { fins de } 1820 \text { e princípios de } 1830 \text {, talvez em Pernambuco, } \\
\text { mas, como não encontrei referência ou exemplar, citei a } \\
\text { edição francesa. }\end{array}$ \\
\hline $\begin{array}{l}156 \\
P\end{array}$ & $\begin{array}{l}\text { Apologia da Religião por oi- } \\
\text { tocentos reis } \$ 800\end{array}$ & $\begin{array}{l}\text { CABRAL, Francisco José. Apologia da relegião. Lisboa: } \\
\text { Imp. Regia, } 1816,14 \text { p., } 15 \mathrm{~cm} \text {. }\end{array}$ \\
\hline $\begin{array}{l}157 \\
F\end{array}$ & $\begin{array}{l}\text { L'espirit de Mosieur (sic) } \\
\text { Nicoli por quatrocentos } r^{s} \\
\$ 400\end{array}$ & $\begin{array}{l}\text { [CERVEAU, René]. L'esprit de m. Nicole, ou instructions } \\
\text { sur les verités de la religion tirées des ouverages de ce } \\
\text { grand théologien tant sur les dogmes de la foi et les mys- } \\
\text { téres, quer sur la morale. Paris: G. Desprez, } 1765 \text {. }\end{array}$ \\
\hline
\end{tabular}


rev. hist. (São Paulo), n. 171, p. 245-286, jul.-dez., 2014 http://dx.doi.org/10.11606/issn.2316-9141.rh.2014.89013
Pablo Antonio Iglesias Magalhães

Deus e o diabo na biblioteca de um cônego da Bahia: 0 inventário dos livros do padre Manoel Dendê Bus em 1836

\begin{tabular}{|c|c|c|}
\hline $\begin{array}{l}158 \\
F\end{array}$ & $\begin{array}{l}\text { Epitres de Voltaire avalia- } \\
\text { dos por trezentos e vinte } r^{.} \\
\$ 320\end{array}$ & $\begin{array}{l}\text { VOLTAIRE. Les trois épîtres. Genève: Cramer, } 1769 . \\
\text { Volume que contém os três épîtres de Voltaire: Épître à } \\
\text { Boileau, ou Mon testament; Épître à l'auteur du nouveau } \\
\text { livre des Trois imposteurs; Épître de m. de Voltaire à m. de } \\
\text { Saint-Lambert. }\end{array}$ \\
\hline $\begin{array}{l}159 \\
P\end{array}$ & $\begin{array}{l}\text { Novo Testamento avalia- } \\
\text { do em cento e sessenta } r^{s} \\
\$ 160\end{array}$ & $\begin{array}{l}\text { O Novo Testamento de Nosso Senhor Jesus Christo / } \\
\text { trad... segundo a Vulgata por Antonio Pereira de Figueire- } \\
\text { do. Londres: Impr. na Off. de Tilling, } 1823 \text {. Londres: Impr. } \\
\text { na Off. de Tilling, 1823, [4], } 848 \text { p., } 13 \mathrm{~cm} \text {. }\end{array}$ \\
\hline $\begin{array}{l}160 \\
F\end{array}$ & $\begin{array}{l}\text { Novo Methodo para a lin- } \\
\text { gua Grega avaliado por set- } \\
\text { tecentos e vinte reis } \$ 720\end{array}$ & $\begin{array}{l}\text { LANCELOT, Claude. Nouvelle méthode pour apprendre } \\
\text { facilement la langue grecque [par C. Lancelot]... Nouvelle } \\
\text { édition enrichie... par MM. B., professeur de rhétorique et } \\
\text { C. N. [Nikolopoulos], de Smyrne. Paris: A. Delalain, } 1819 \text {. } \\
\text { A edição original da gramática grega de Claude Lancelot } \\
\text { data do século XVII. Muitas outras foram impressas ao } \\
\text { longo dos séculos XVIII e XIX. Não é possível precisar } \\
\text { qual a edição no inventário. }\end{array}$ \\
\hline $\begin{array}{l}161 \\
F\end{array}$ & $\begin{array}{l}\text { Diccionario Geografico ava- } \\
\text { liado por oitocentos reis } \\
\$ 800\end{array}$ & $\begin{array}{l}\text { VOSGIEN, Jean-Baptiste. Dictionnaire géographique } \\
\text { portatif, ou description de tous les royaumes, provinces, } \\
\text { villes, patriarchats, evechés. Traduit de l'anglois sur la trei- } \\
\text { zième éd. de Laurent Echard, avec des additions et des } \\
\text { corrections considérables, par m. Vosgien. Paris: Didot, } \\
1747,250 \mathrm{ff}, \text { in-8. } \\
\text { O Dicionário geográfico do advogado Vosgien teve algu- } \\
\text { mas dezenas de primeiras edições na França durante o } \\
\text { século XVIII e as primeirs décadas do século XIX. Impos- } \\
\text { sível saber de que edição se trata. }\end{array}$ \\
\hline \multirow[t]{2}{*}{$\begin{array}{l}162 \\
F\end{array}$} & $\begin{array}{l}\text { Eraste avalia [fl. } 46 \mathrm{v}] \text { ava- } \\
\text { liado por mil duzentos e oi- } \\
\text { tenta reis } 1 \$ 280\end{array}$ & $\begin{array}{l}\text { FRANÇA, Domingos Ribeiro. Erasto, ou o amigo da moci- } \\
\text { dade: conversações familiares, nas quaes á mocidade de } \\
\text { ambos os sexos se dão sufficientes noções sobre a maior } \\
\text { parte dos conhecimentos humanos. Obra interessante } \\
\text { etc. Segunda edição de novo traduzida, e conforme com a } \\
\text { quinta e ultima de Paris. Coimbra: na Imp. da Universida- } \\
\text { de, } 1822,275 \text { p., in }-8^{\circ} \text {. } \\
\text { Apesar de já haver essa tradução portuguesa, creio que o } \\
\text { exemplar do inventário tenha sido alguma das cinco edi- } \\
\text { ções impressas no original francês. }\end{array}$ \\
\hline & $190 \$ 840$ & \\
\hline $\begin{array}{l}163 \\
P\end{array}$ & $\begin{array}{l}\text { Escola popular avaliada por } \\
\text { seiscentos e quarenta reis } \\
\$ 640\end{array}$ & $\begin{array}{l}\text { Eschola popular das primeiras letras, dividida em quatro } \\
\text { partes. Coimbra: Real Imp. da Universidade, } 1796,62 \text { p., } \\
17 \mathrm{~cm} \text {. } 2 \text { a ed. Coimbra: Real Imp. da Universidade, } 1829 \text {, } \\
32 \text { p., } 18 \mathrm{~cm} \text {. }\end{array}$ \\
\hline $\begin{array}{l}164 \\
\text { IT }\end{array}$ & $\begin{array}{l}\text { Alfieri Delia (sic) Terannede } \\
\text { por quatrocentos reis } \$ 400\end{array}$ & $\begin{array}{l}\text { ALFIERI, Vittorio. Della tirannide di Vittorio Alfieri da Asti. } \\
\text { Turim: Stamperia Filantropica, ano IX, 1800, } 2 \text { vol., } 170 \\
\text { p., } 96 \text { [4] p., } 8,5 \times 12,5 \mathrm{~cm} \text {. } \\
\text { Escritos em Siena no ano de } 1777 \text {, os dois livros de Della } \\
\text { Tirannide foram retocados em Paris em } 1787 \text { e publicados } \\
\text { contra a vontade do autor em } 1800 \text { e } 1801 .\end{array}$ \\
\hline
\end{tabular}


rev. hist. (São Paulo), n. 171, p. 245-286, jul.-dez., 2014 http://dx.doi.org/10.11606/issn.2316-9141.rh.2014.89013
Pablo Antonio Iglesias Magalhães

Deus e o diabo na biblioteca de um cônego da Bahia: 0 inventário dos livros do padre Manoel Dendê Bus em 1836

\begin{tabular}{|c|c|c|}
\hline $\begin{array}{l}165 \\
L\end{array}$ & $\begin{array}{l}\text { Burssure (sic) Flosculi his- } \\
\text { toriarum por quatrocentos } \\
\text { reis } \$ 400\end{array}$ & $\begin{array}{l}\text { BUSSIĖRES, Jean. Flosculi historiarum delibati ex rebus } \\
\text { paecipuis aue ab orbe condito ad nostra tempora conti- } \\
\text { gerunt. Editio quarta. Ioan. Bapt. Devenet. Lugduni [Lyon], } \\
1659,2 \text { tomos emum vol., } 8^{\circ},[6]+184+[16],[12]+350+[18] \text { p. } \\
\text { Flosculi historiarum, delibati ex rebus praecipuis quae ab } \\
\text { orbe condito ad nostra tempora contigerunt / Auctore Jo- } \\
\text { annne de Bussieres. Venetiis: Typis Josephi Tramontini, } \\
1685 \text {. }\end{array}$ \\
\hline $\begin{array}{l}166 \\
P\end{array}$ & $\begin{array}{l}\text { Hymnologia Sacra por seis- } \\
\text { centos e quarenta r.s } \$ 640\end{array}$ & $\begin{array}{l}\text { ASSUNÇÃO, José da. Hymnologia sacra... / dedicada à } \\
\text { imperatriz do Ceo Maria Santissima...seu author op. m. } \\
\text { fr. José da Assumpção. Lisboa: [na Offic. da Congrega- } \\
\text { ção do Oratorio]: na Offic. de Miguel Manescal da Costa, } \\
1738,2 \text { vol., } 4^{\circ}, 20 \mathrm{~cm} \text {. }\end{array}$ \\
\hline $\begin{array}{l}167 \\
\text { IT }\end{array}$ & $\begin{array}{l}\text { II Pastor Fido dois volumes } \\
\text { em oitavo avaliado por seis- } \\
\text { centos e quarenta reis } \$ 640\end{array}$ & $\begin{array}{l}\text { GUARINI, Giovanni Battista. Pastor Fido. Londra: presso } \\
\text { A. Dulau e Co. Soho-Square, (dalla stamperia di L. Nardini } \\
\text { e A. Dulau e Co. n } 15 \text {, Poland Street), M.DCCC, } 8^{\circ} \text { p. [6], } \\
\text { 208, [4], } 168,2 \text { vol., in-8. } \\
\text { O livro do cavaleiro Guarini foi constantemente publicado } \\
\text { em volume único, desde o século XVI. As edições de Lon- } \\
\text { dres foram impressas, contudo, em dois volumes. Teve } \\
\text { reedições em } 1809 \text { e 1816, mas ambas in-24. Apenas a } \\
\text { acima indicada é in-8. Essa obra foi vertida para o portu- } \\
\text { guês por Thome Joaquim Gonzaga e publicada em } 1791 .\end{array}$ \\
\hline $\begin{array}{l}168 \\
P\end{array}$ & $\begin{array}{l}\text { Abreu de Parochi hum vo- } \\
\text { lume avaliado em novecen- } \\
\text { tos e sessenta reis } \$ 960\end{array}$ & $\begin{array}{l}\text { ABREU, Sebastião de. Institutio parochi seu speculum pa- } \\
\text { rochorum... / authore... Sebastiano da Abreu. Eborae: ex } \\
\text { Typographia Academiae, 1665, [22], 906, } 102 \text { p., } 2^{\circ}, 28 \mathrm{~cm} \text {. } \\
\text { Pela mesma tipografia, pude ver edições de } 1681 \text { e } 1700 .\end{array}$ \\
\hline $\begin{array}{l}169 \\
L\end{array}$ & $\begin{array}{l}\text { Quintus Curtius Rufus por } \\
\text { trezentos e vinte reis } \$ 320\end{array}$ & $\begin{array}{l}\text { RUFUS, Quintus Cutius. Quintus Curtii Rufi De rebus ges- } \\
\text { pis Alexandri Magni... I Interpretatione et notis illustravit } \\
\text { Michael Le Tellier... - Q. Cvrtii Rvfi. Historiarum libri accu- } \\
\text { ratissime editi. Parisiis: apud Fredericum Leonard, } 1678 . \\
\text { Lvgd. Batavorvm: ex officina Elzeviriana, 1656, [10] } 238 \\
\text { [21] p., il., } 1 \text { mapa desdobrável, in-4, } 12,5 \mathrm{~cm} \text {. } \\
\text { Uma das muitas edições dos Feitos de Alexandre. O } \\
\text { exemplar acima se encontra na Biblioteca Nacional do } \\
\text { Rio de Janeiro. }\end{array}$ \\
\hline $\begin{array}{l}170 \\
D\end{array}$ & $\begin{array}{l}\text { Logica hum volume em oi- } \\
\text { tavo avaliado por cento e } \\
\text { sessenta reis } \$ 160\end{array}$ & $\begin{array}{l}\text { Impossível saber de que livro se trata. Muitos livros em di- } \\
\text { versas línguas tem "Logica" no título. Á época do inventário, } \\
\text { estava na moda a Logica do Eugênio Genuense. A tradução } \\
\text { portuguesa de Souza Farinha, por exemplo, é in-8: } \\
\text { Liçõens de logica feitas para o uzo dos prinicipiantes / por } \\
\text { Antonio Genuense; tresladadas em linguagem por Bento } \\
\text { José de Souza Farinha... Segunda ediçam mais castiga- } \\
\text { da e emendada. Lisboa: na Officina de Antonio Gomes, } \\
1794,160 \text { p., in-8, } 15 \mathrm{~cm} \text {. }\end{array}$ \\
\hline $\begin{array}{l}171 \\
L\end{array}$ & $\begin{array}{l}\text { Martialis epigramma hum } \\
\text { volume avaliado por cento } \\
\text { e sessenta reis } \$ 160\end{array}$ & $\begin{array}{l}\text { MARCIAL, Marcos Valério. M. Valerii Martialis Epigramma- } \\
\text { tum libros XV. / Interpretatione et notis illustravit Vincentius } \\
\text { Collesso. Parisiis: apud Antonium Cellier, 1680, in-4. } \\
\text { Uma das muitas edições da obra de Marcial. O exemplar } \\
\text { acima se encontra na Biblioteca Nacional do Rio de Janeiro. }\end{array}$ \\
\hline
\end{tabular}


rev. hist. (São Paulo), n. 171, p. 245-286, jul.-dez., 2014 http://dx.doi.org/10.11606/issn.2316-9141.rh.2014.89013
Pablo Antonio Iglesias Magalhães

Deus e o diabo na biblioteca de um cônego da Bahia: 0 inventário dos livros do padre Manoel Dendê Bus em 1836

\begin{tabular}{|c|c|c|}
\hline $\begin{array}{l}172 \\
\text { L }\end{array}$ & $\begin{array}{l}\text { Ausonii Popmae hum volu- } \\
\text { me em quarto avaliado por } \\
\text { cento e sessenta reis } \$ 160\end{array}$ & Ver item 54. \\
\hline & $196 \$ 600$ & \\
\hline $\begin{array}{l}173 \\
\mathrm{~L}\end{array}$ & $\begin{array}{l}\text { [fl. 47] Marci Tullii Ciceronis } \\
\text { avaliado por trezentos e } \\
\text { vinte reis } \$ 320\end{array}$ & $\begin{array}{l}\text { CICERO, Marco Túlio. Libri tres de officiis addito Catone } \\
\text { maiore Laelio paradoxis et semnio Scipionis ex recensio- } \\
\text { ne Isaaci Verburgii. Olisipone: Simonis Thaddaei Ferre- } \\
\text { riae, } 1791,19,450 \text { p., } 19 \mathrm{~cm} \text {. }\end{array}$ \\
\hline $\begin{array}{l}174 \\
P\end{array}$ & $\begin{array}{l}\text { Doutrina das Acçoens em } \\
\text { quarto hum volume avalia- } \\
\text { do por trezentos e vinte r. }{ }^{s} \\
\$ 320\end{array}$ & $\begin{array}{l}\text { TELES, José Homem Correia. Doutrina das acções ac- } \\
\text { commodadas ao foro de Portugal. Coimbra: Real Impren- } \\
\text { sa da Universidade, } 1819 \text {. VII, } 220 \text { p., } 21 \mathrm{~cm} \text {. } 2 \text { a ed. Lis- } \\
\text { boa: na Impressão Regia, } 1824, \text { VII, } 220 \text { p., } 22 \mathrm{~cm} \text {. }\end{array}$ \\
\hline $\begin{array}{l}175 \\
P\end{array}$ & $\begin{array}{l}\text { Primeiras Linhas volumes } \\
\text { segundo, terceiro, e quarto } \\
\text { folheto avaliados por seis- } \\
\text { centos e quarenta reis } \$ 640\end{array}$ & $\begin{array}{l}\text { SOUSA, Joaquim José Caetano Pereira e. Primeiras li- } \\
\text { nhas sobre o processo civil. Lisboa: na Typ. Lacerdina, } \\
1810 \text {. } \\
\text { Primeiras linhas sobre o processo civil/ por Joaquim José. } \\
\text { Segunda ediçao correcta, e accrescentada. Lisboa: na } \\
\text { Typ. Rollandiana, 1819. 3a ed. Lisboa: Typ. Rollandiana, } \\
\text { 1825. }\end{array}$ \\
\hline $\begin{array}{l}176 \\
P\end{array}$ & $\begin{array}{l}\text { Acçoens Episcopaes ava- } \\
\text { liado por trezentos e vinte } \\
\text { r. }^{s} \$ 320\end{array}$ & $\begin{array}{l}\text { D'ANDRADE, Lucas. Acçoens episcopaes tiradas do pon- } \\
\text { tifical romano e ceremonial dos bispos: com hum breve } \\
\text { compendio dos poderes, e privilegios dos bispos. Lisboa: } \\
\text { na Officina de Joam da Costa, } 1671 \text { [18], } 170 \text { [10] p., } 2 \\
\text { grav. calcogr., il., } 4^{\circ}, 19 \mathrm{~cm} \text {. }\end{array}$ \\
\hline & $198 \$ 200$ & \\
\hline
\end{tabular}

Por estarem os referidos livros estragados e outros truncados lhes derão os mencionados valores; e para constar fiz este termo, em que assignarão o Juiz, o Inventariante, e Avaliadores e o Livreiro. E eu José Olympio Gomes de Souza Escrivão o escrevi.

Dr. Per. ${ }^{a}$ de And. ${ }^{e}$

José Paulo Franco Lima

Francisco Nunes Tupiniquim

Joaquim J.e Tiburcio

Joaq. ${ }^{\mathrm{m}} \mathrm{J} .{ }^{\mathrm{e}}$ de Moraes

Recebido: 28/04/2014 - Aprovado: 03/11/2014 